ESTEKS OF GENTISIC ACID AND THBIK TOXICITIKS

\title{
DI SSERTATION
}

Prosented in Partial Fulfildment of the Requirements

for the Dogreo Doctor of Philosophy in the Graduate Sohool or The Oh10 State University

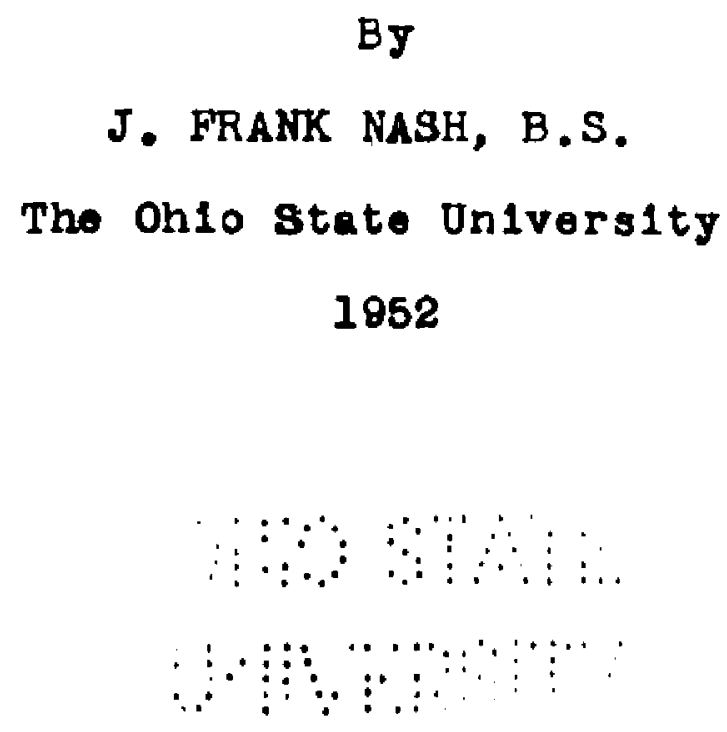

Approved by:

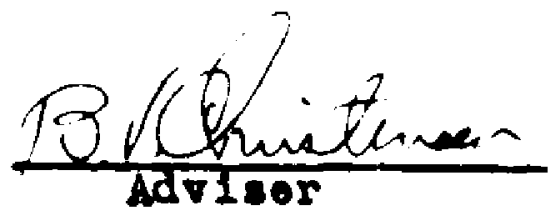


TABLX OP CONTENTS

Page

IN TRODUC TI ON. .............................. I

DI\$CUSSION OF THE LITEKATURE.................. 3

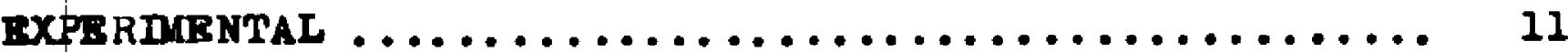

Now Gent1a10 Ac1d Batera..................... 22

D10 thylaminoo thyl Gent1sato Hydroohlor1de......... 22

a. Proparation......................... 22

b. Properties.......................... 27

D10 thylaminoe thyl 5-Acetyl-Gont1sate Hydrochlor1de.. 28

a. Proparation......................... 28

3. Propert1os......................... 32

Dio thylaminoe thyl 5-Me thoxy-Gent1sete Hydroohloride. 33

a. Proparation......................... 33

b. Propert1os.......................... 35

D10 thylam Inoothyl 5-Benzoyl-oentlate Hydrochloride. 36

. Proparation......................... 36

b. Properties.......................... 38

D10thylaminopropyl Gent1sa to Hydroohlor1do........ 39

a. Proparation......................... 39

b. Properties......................... 41

Die thylaminopropy 5-10etyl-Gent1ate Hydroohlor1de, 42

a. Preparation.......................... 42

b. Proportios...........................43

D1e thylaminopropjl 5-Mothoxy-Gont1sato Hydroohlorido 44

a. Preparation.......................... 44

b. Proportios........................... 45

\section{6;}


Diethylaminopropyl 5-benzoyl-Gent1se to Hydrochloride 46

a. Proparation........................46

b. Properties..........................47

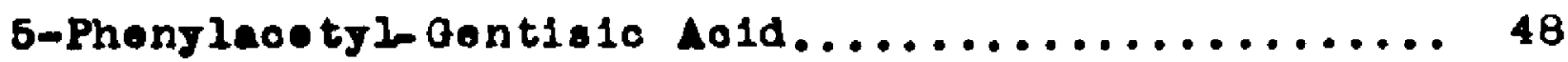

a. Proparation......................... 48

b. Propert1ea.......................... 50

5-Parantrobenzoyl-Gent1a10 Ac1d.............. 51

a. Proparation.......................... 51

b. Propert1es......................... 52

5-Anisjl-gontisio Ac1d.................... 53

a. Proparation........................ 53

b. Proport1es.......................... 55

5-Aootylaelloglogent1o10 Ao1d................ 56

a. Proparation........................ 56

b. Proport1es........................... 57

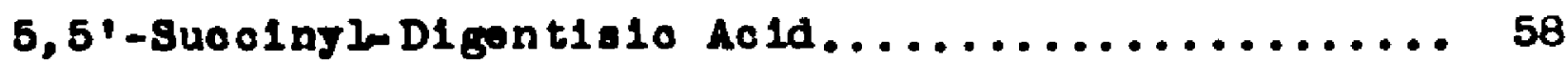

a. Proparation....................... 58

b. Propert100............................60

Proof of the Struoture of the Synthosized Baters by

the Analjoes of their Infrared Spootra...........6 61

Infrared Spootra and Interpretation...........65

Toxio1ty Touta......................... 78

Toxiolty of Carboxyl10 Ao1d Batera of Gentiolo Aold 81 Taxiolty of Phonolio Eaters or Gentisio 101d..... 87

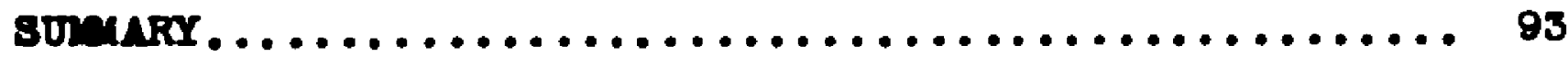
comcusrows................................ 103

BIBLT OQRATH. ............................. 108 AITMETOCRATY. 112 


\section{NDEX TO TABLES}

Tables

Page

I. Wave Longth of absorption by functional groups

In tho infrarod opootra................ 65

II. Analyses of Infrared Speotra of Known Compounds 68

III. Analjee of Infrared Spootra of Diotramino-

- thanol Eators of Gentisio Ao1d............

IV. Analyses of Infrarod Speotra of Diottilamino-

- thanol Bators of Gont1a10 1o1d............73

v. Analyaes of Infrared Spootra of Phonolic Bators of Gont1s10 $101 d \ldots \ldots \ldots \ldots \ldots \ldots \ldots \ldots \ldots \ldots \ldots \ldots \ldots$

VI. W50 of D1ethjlaminoethjl Gentisete HJdroohloride.

VII. ID 50 of D10 thylaminoethyl 5-Acotyl-dentisate Hydroahlor 1de.

VII. IDso of D10thylaminoethyl 5-Me thoxy-Gentiea to Hydroohlor1do.........................

IX. ID 50 of D1e thylaminoethyl 5-benzoyl-Gont1sate Hydroohlor1de.........................

X. Iso of D10 thylaminopropyl Gentisato HJdroobloride..............................

XI. D $_{60}$ of D10 thylaninopropsl 5-Aoetyl-Gentide to Hjdroohloride.

XII. ID 50 of DIethylaminopropyl 5-Methoxy -Oent1 eate Hrdroohlor 1do. B4

XIII. ID SO $_{\text {of }}$ DIethylaminopropjl 5-bensojl-Gentisa to HJdroohloride........................ 
Tebles

$\underline{\text { Page }}$

XIV. $D_{50}$ of 5-Phenylacetyl-Gentisic Ac1d....... 87 XV. ID 50 of 5-Paranttrobenzogl-Gontio10 101 d.... 87 XVI. $\mathrm{D}_{50}$ of 5-Aniegl-Gent1a10 Ac1d........... 87 XVII. ID 50 of 5-Acetylanlioyl-Gentialc Ao1d....... 88 XVIII. $\mathrm{D}_{50}$ of $5,51-$ Suocingl-Digent1sio Ac1d....... 88 XIX. $\mathrm{D}_{50}$ of Gontia1c $101 \mathrm{~d} \ldots \ldots \ldots \ldots \ldots \ldots . \ldots . \ldots 8$ xx. Analysea of Synthosized Compounds.......... 99 XXI. Proporties of Synthosised Compounds......... 101 


\section{IMDIX TO FIQURBS}

Plgurea

Page

1. Infrared Spootrum of Gentis10 Ac1d...........66

2. Infrared Speotrum of 5-1oetjl-Gent1s10 Ac1d.... 66

3. Infrared Speotrum of 5-Methoxy-Gont1a10 $101 d . \ldots 66$

4. Infrared Spootrun of 5-Benzojl-Gent1a10 Ao1d.... 67

5. Infrared Speotrum or D1acetyl-Gent1a10 Ao1d..... 67

6. Infrared Spectrum of D1othylaminoethyl Gentisato Hydrochloride.........................

7. Infrared Speotrum of D10 thylaminoothyl 5-AcetylGonticate Hydrochloride..................69

8. Infrared speotrum or D1ethylaminoethyl 5-

No thoxy-Gont1se to Hydroohlorlde..............66

9. Infrared Speotrum of Die thylaminoe thyl 5-

Bensoyl-Gent1eate Hydroohlor1de.............69

10. Infrared Spootrun of D1ethylaminopropyl Gent1-

sete Hydroohloride.......................

70

11. Infrared Speotrum of Diethylaminopropyl 5Loetyl-Gentigato.......................

12. Infrared Speotrum of D10 thylaminopropyl 5-

Mo thoxy-Gent1sa to Hydroohloride..............70

13. Infrered Speotrum of D10 thylaminopropjl 5-

Bensojlmontlaste Hydroohloride............. 72

14. Infrared spootrum of 6-Phenjlaoetjl-Gent1sio Ao1d 72

15. Infrared Spootrum or 5-Paran1trobenzoyl-Gent1a10 Ao1d. 
16. Infrarod spootrum of 5-Aniagl-Gontisic Acid... 74

17. Infrared Speotrus of 5-10etylabliogl-Gentisic

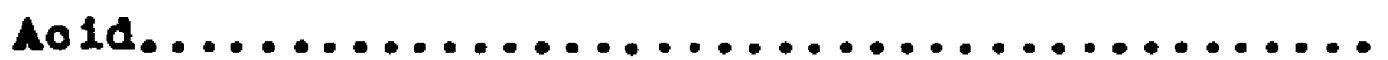

18. Infrared spectrum of 5,5'-Sucolnyl-Digent1010

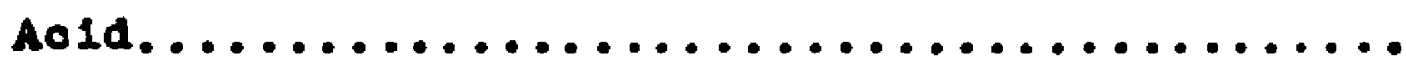

19. Graph of $\mathbf{L D}_{50}$ or Diethylaminoethyl Fatera of Gent1sio Ac1d and Substitutod Gont1sio Ao1ds.. B3 20. Graph of $\mathrm{ID}_{50}$ of D10 thylaminopropyl Eaters of Gont1e10 101d and Substitutod Gont1a10 101do.. 85 21. Graph of $\mathrm{ID}_{50}$ of Phonolio Eaters of Gentisic

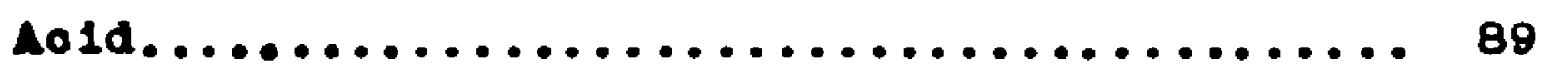
22. Graph or $I D_{50}$ or Gent1o10 $101 d \ldots . . . . . . . . .90$ 


\section{ACKNOWLEDGMENI'S}

I wish to acknowledge with gratitude the advice and auggestions of Dr. Bernard V. Christensen, Dean of the collogo of Pharmaoy, in the dovelopment of this thosia.

To Dr. Frank W. Bope I am greatly indobted for the thought, timo, and pationoo whilo this thosis wa dovelopod.

I aloow1sh to acknowlodge the advise and suggogtions of Dr. John W. Nolson in the development of the toxic1ty prooedure.

I acknowledge the suggestions of Dr. Melvin S. Neman, of the Chomlatry Department, in the dovolopment of the gytheoes.

A spoolal note or approciation is extended to Dr. Chr1stopher Wilmon, of the Chomiatry Depertment, for uso of the Infrared laboratory.

The Finanolal asolatanoe of the Upjohn Company, in the form of a followahip, and of the Unitod Statea Government, In the nature of Publio Iaw 346, is rosponalblo in a largo mosoure for this thosia.

I wiah to thank the Bl1 Lilly Company for the Carbon and Hydrogen analyaes.

To all othors who have asalatod in any way, I wish to exprese elnoere thanks and graterul appreciation. 
ESTFKS Or' GFNTISIC ACID aND THFIl, TOXICITIKS

\section{INTKODUCTION}

The preparation of some now ostors of 2,5 -dingdroxybenzolo ac1d or gentisio aold whioh offer possiblitties of beling or modlolnal value as antirhoumatics, antiarthritics, or analgesios was auggeated by soveral faotors. First, in epite of tho wide attention given to adronal oortical hormonea, there 1s at1ll great nood for good modicinal agenta for the troatment and symptomatio relief of rhuomatic and arthrit10 disorders. S1nce treatment of these disordors 1. usually of long duration, 1t is desirablo to use med1olnal agente of 10w toxiolty, and also agents that w111 produce a minimum of alteration of normal phyelologic funotions. Compounds suoh as the sal1c:-ates have boen used in thls oapaoity for many joara.

A seoond factor suggesting this work is the lnoreasing use of sodium gentisate in the treatment of rhoumatio cond1tions and an analget1o.

st1ll another factor suggesting preparation of some orters of gentisio aold 1a the apparent noed for an officiont non-addloting analgosio strongor than aspirin yot woaker than the opiatea.

The groups ohosen to be ooupled with gentisic ac1d were groups of oatabliahed pharmacologloal aotivity. DlothylamInoe thanol has pronounced analgosio offoct without ang toxic 
alde-aotions when injeoted intravenously (1). Also, diethylaminoothanol appoars to have analgosic properties when given orally or intramuscularly (2). This grouplrig is also prominont in local anesthet1os, antispasmodica, and antiniataminios. Diethylaminopropanol was used to determino the effeot of an additional oarbon in the alcohol.

soetglealloylic and suoolnic aids are both analgesios or proven modiolnal value.

Phonjleoot1o ac1d estera have proven antiapasmodic eotivity and phonglalkylaminos are analgoolc (3).

Paranitrobenso10 ao1d and moro particularly 1 ts roduction produot, paraminobenzolo aold, has varioty 0 : pharmooologloel propertios among which are looal anesthetio and ant1-infeotive erfeotn.

Anie10 ao1d or parame thoxybenzo10 ac1d is reportad to have antirhouratio and looal anesthetio aotivity (4). soetyl, wothoxy and benzoyl groups were substituted in the oarboxyl10 cold outers beoaues of the proven value or the we funotions in onhanoing the analgesio value of phonolio ocopounds. 


\section{DISCUSSION OF THE LITERATUKE}

Although alloglic aold and sodium salloylate have boen used in the treatment of rhoumatio oonditions alnoe 1876 and 1877. roapoctively (5), ballojl10 ao1d's oxidation product. gont1e10 ao1d, romalned unknown mediolnalig unt1l september, 1948 when Mejer and Regon reported the use of sodium gentiate for the rellef or rheumet10 aymptome (6). S1noe then, numeroug reporta from the Wostorn Homisphere have aubstant1ated the original bollef of Moyer and Ragen.

The epecific efrect of alioylates upon the activity of hyaluronidace and salioglato aotion in rhoumatio conditions date back to the work of Guerre in 1946 (7) (B). Guerra bel1evea rheumatio fever to be a disoase of the mesenohyma t1 asues. During the erolution of the diseene, whe ther of baotorial or ondogenous origin, permeablilty ohanges take plaoe polnting to interrelationahip or aeveral oharaoteristios of rhounation and the epreading raotors of oonneotive t1esue.

The Importanoe of the apreading effect of hyaluronidase on conneotire tianue is based on the obmervation of Moyer and Palmer (9), who polnted out that hjaluronio aoid 10 tho prinolpal subatrato or connootive tissue and wuooid atruoturea. Conneotive tissue and muoold atruotures ompose almost entirely tho rogion: arrooted by rheumatiam, ouch as artioulations and ejnovial rluid. 
Durhn-Rognals (10), Mocloan (11), Kondall and associatos (12), and ospolallj Crowley (13), have observed that soveral mloroorganlame inoluding wore than 200 otralns of hemolyt10 atreptoool produce or posenes hyaluropidase.

Guerre bowed that hyaluronidase of baoterial origin or from teetioular extraot, in 26 dilutions, inoreased tho epread of brane Blue in humane and Indla Ink in rabblts. The opreading reaultod from ensymatio eotirity whioh hjdroljeod the hraluron10 aold prosent. The y1s00sity was deoreased and, therefore, the paseage of 11quide, exudates and pathogen10 aloroorganlave was favored (7).

sodiu alleglato adminietered orally or intravenoualy In dosage of $0.079 \mathrm{~g} . / \mathrm{Kg}$. oaused $\mathrm{b} 7 \mathrm{k}$ roduotion of skin diffusion effeot of hjaluronidase in rabbita, oompared to saline oontrols. A dose of $0.10 \mathrm{~B} . / \mathrm{Kg}$. . by the same routes of adminletration, oaused 6e\% reduotion of diffusion effeot. Moreover, hwens who had oontaoted rhoumatio fever, upon Intradermal injeotion of a mixture of hjaluronidace with Drane Blue gare unique reatione 1 th enormoue diffusion of the dye and looal edeme that eomotimes ocoupled the arm 1njeotod. Saliojlates in those oases Inhibitud the gotivity of the ensyes and reduoed its aproading effeot in oonneotive t1seue. Guerre, thempore bellered that the actiritj of the eallojlates wae due to the Inhibition of the aotivity of hraluronidese (B).

It has been desonatrated that eallojlatos do not inhlbit 
the aotivity of hyaluronidase in as low ooncentrations in vitro as thoy do in pivo (6), (14), (15), (16), (17). swyer (17), by ueing the visooelmetrio toohnique in vitro, rooorded no direot inhibitory erfoot on the eotivity of hjaluronidase by sodium saliojlate or acetylsalioglio aold excopt at relativelJ high oonoentrations, 1.9. greator than 3 and $0.33 \%$, reapootively. suoh 1 nhibition at the so conoentration. 18 apparentis due to lowering of $\mathrm{pH}$ and, in the oade of sodium allojlate, to the inoreased ooncentration of selt. swjer belleved the reaults obtalned by Guerra were due to the precenoe of histamine or come subatanoe of olmilar cotion, and that sodiug calioylate, by inhibiting the cotivity of the aubatance reduced the apparent aproading efreot oaused by hyaluronidase.

Mojer and Ragen (6), (18) olaimod that the inhibition or hyaluranidase notivity was due to the faot that alloyletes are converted to gentialo nold whioh aots as tho true Inhlb1tor. The eemi-quinone formod oondenees in an 1rreveralble manner with the ensjme. Sallojlates are known to J101d from \& to 8\% gentle10 ac1d (5), (19), (20). Th1e aubatantiatea the atatement that 2,5 benzoquinono oarboxyl10 aold Inhibita the aotivity of hyaluronidase (21).

However, Rosoman ot al (22) howed pure analytical gentilio eoid to be dovold of hyaluronidase inhibitory aotivity. The orude gentisio acid a woll as pure gentisio coid treated with alkell in the presenoe of air did ahow 
ectivity. Similar results wore obtained with homogentialo ao1d. Therefore, it was oonoluded that the aotivity of gent1sio aold wae probably due to impuritiog in the product wloh have been formed bj oxidation. The work of Lowenthal and Gagnon (23) Indloated the same laok of Inhibitory aot1r1 ty of gentie10 ao1d.

A lieting of producte that inhibit the aotivity of hyaluronidase showe the aotivity of phonol substituted produote Inoreaces with inorease in length of tho hydro-

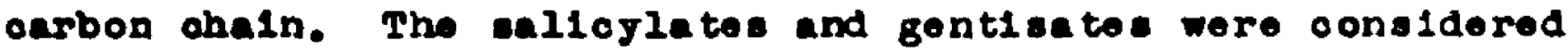
Inective in vitro (24).

Guersa al wo showed that gluouronic aold exoretion Inoreasea in the urine, upon injeotion of alloglates. However, gentialo cold diminiahes tho exoretion of this produot. Sinoe hyeluronic aold is oomposed of D-gluoosamibe, gluouronic ao1d and N-aoetjlgluoosamine, the cotion of gentisio ao1d appoere to be desirable in roapoot to exoretion (25). Anothor ocuse of rhoumatold arthritis has boen thought to be hormone imbalanoe (19). The selioglatos maj imulato the adrenal oortex oauaing liberation of oortloold subetanoe. Adrenel oortioel stimuletion oan be demonstrated in rete and guinea pige bJ an Inoreace in exoretion of urinary 12 ketosteroide and a dooreace in olroulating oosinoph1 is (26). However, a deoreace in olroulating oosinoph1ls could not be found after administration of anliojlatos or gontisatos to 
four medioal etudenta. Thiobst ot al, (27) trjing to correlate rhounat10 arthrit1s and pormeability of the eynovial mombrane howed sodium salloglate rotards pormeablilty more than oodiun gentiante. The rotardation was based upon the Injeotion of phonglphthalein into the Intrartioule and then rooording the time for appearanoe of urinary ooloration. The retardation bas a ravorable aotion in rhounet1o arthritia. The meohaniaw of eotion wae oonoluded to be conneotod with the funotion of the euprerenal oortex.

sinoe 1948 there hae been extenalve work done in the Onitod states, Pranoo, Britian, and Italy in rogard to the use or gentiates for rheumatio oonditions and analgeala. In rhoumatio fover, Mejer and Ragen (6) roport uniformly good rovulta ueing codium gentisato thorapy. Tho administration or codium gentleate was followed by diappearanoe of pain, alloviation of awelling and hot in jolnte, lowering of temperature to normal and bJ the falling of the gedimentation rate to normal. In most onges tho disease was alleriated for f17e to ton monthe after romoval of codlum gontisate thorapy. However, even in those oaces whore the disesse returned in noveral daja, It could again be relleved bj adminietration or codiue genticato. Sohaefer et al (28) and othore (29) also obtalnod good therepoutio reaulta with oodium gontiato in rhoumat10 Sever.

wejer and Ragen (6) also used gontisateg to troat pationts arriloted w1th rhoumatold arthritia. Resulta woro favorablo. 
Came 11n, ot al (5) an well as Ory (30) and others (31) working with large groupe of patients obtained oncouraging reculte in rhounatold arthritle and Boulliard disease. Ory also reported eodium gentiante to be valuable in gout.

Batterman, ot al (32) atudied the analgesio offects of eodiu gentisates in approximately 100 oager. Control of paln regardiese of eerer1tj, diagnosis, or dosage administration for hospltalized patients was obtained in $71 \%$ or the tr1ale, without a anglo onse of toxiolty. Satiefaotory analgenie ooourred in $57 \%$ of tho ambulatory pationts. Untoward reactione were noted in $11 \%$ of the ambulatory pationta, but thie wae within the experimontal range of plaooboa. sinos the aotivity of sodium gentisato is in the amo range as thet of allojlates all the roportion aotivity are relative to that of codiur aaliojlate. Aocording to the Ilterature the gontiates offor the following advantages orer the allejlated in the above diseases. I. Sodlum centiate remorea one etep in the motabol10 prooese. saliojletor ero oxidizod to gentieated before thoj are offootlve, so bJ giving eodlum gentisate wo givo the active drug. 2. Sodium gentisate 1s not as imitating as the ealiojletes to the gectrio muooea. The gastrio syotem appeara to be able to take in an unlimited amount. 3 . Intrarenous injeotion oaseer no colerosis; muacular toleranoe is good, and the ronal funotions are not arreoted. 4 . No oase bae jet veen reported showing tho developwent of tinnitus or 
agne of sal10jlim rosulting from use of sodium gentioate. No aural ayptoms or inoreased prothrombin time has boen reported. 5. There are no Indloctions that oodium gentisate

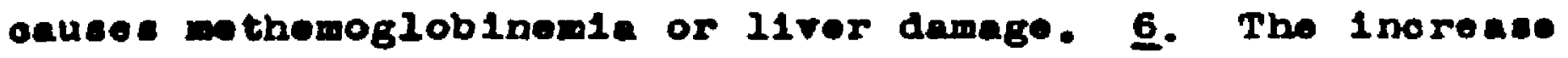
in urinary gluouronic eold exoretion observed with enlioglate Ingestion doe not ooour with sodius gentiente.

In ap1te of numerous reports to tho oontrary, Caprett1 and Anduin1 (35) roport gentisato therapy to bo loas efrootive than ealioglate regime in the trestment of Boulliard d1 19000.

Although rooentls gentiolo ao1d has boon roported to dieappear from the body bJ urinary exoretion and motaboliam to unknown produote (19) (20) as oarly as 1895 Ilkhatscharf (34) reportad a urinary inorease of ethyloulfurio aold after adminiotration of gentilio aold to dogs. Tho same result was obtained by 3 taub and assooiates (35) in 1932.

The only extenelve report on the toxiolty and pharmacologj of gentisio aold was by olnoulhiao and asoolates (36). The report inoludes tho oomparioon of adium gentian to and codiu enilojlate. The ID60 for rate by intreperitionod Injeotion was $3.1 \mathrm{~g} . / \mathrm{K}_{8}$. and $0.88 \mathrm{~g} . / \mathrm{K}_{8}$ respootivelJ. 0ralls, the $\mathrm{ID}_{80}$ for codium gentieate oould not be determined beouse the drug wae well toleratod oven at the dosage lovel of $5 \mathrm{~s} . / \mathrm{K}_{8}$. However, the oral $\mathrm{H}_{50}$ for eodium anlioglato was round to be $2.02 \mathrm{~B} . / \mathrm{Kg}$.

The two aruge were soreoned for soveral aotivitios. 
1. Ne1tbor drug howed notioeable notion on sooth musole f1bers. 3. Sodfum gontiate ahomed littlo or no hyportensive eotivitj excopt at high dosage lovele, but sodium eallejlate gave rosponse or hlgher nature and longer duration. 3. Nolther drug exhibited notab2o antinistaminio cotion. 4. Both druge showed anti-odoma aotivitj but

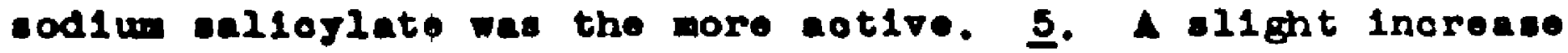
of b1le flow was produoed by both druga in doses of $100 \mathrm{mg} . / \mathrm{Kg}$. 6. Tho mioroblologioal aotivity of sodium gonticete against eevoral strains of baotorla and fungl was very modorate or n12 and Inferior, to that of odlum alloylate in oqual oonoentratione of Ilquid modium.

In epite of the faot that oror 100 subetituted ac1da, phenol10 eatora and oarboxy110 ao1d ostera have beon propared none of the de deplrative have boen to atod pharmacologioally to determine if thes have therapeutio value (37). However, In 1961 a. $\mathrm{U}$. patent wae leaued to Hoffer in whioh ho propared oomplexes of gentia10 oold with antipyrine, 1eopropy 1atipjrino and 4timothjlanino antipjrine to jlold oompound. that poseeseed apt1pyret10 and ant1rhoumet10 not1vity (38). Tbese products wore aleo patented in Germang (39).

The form of gent1sio ao1d oomerolally avallable 18 the sodiu nalt. Tho dosage form 1s oompresend tablete of seven graine. A disoupeion on tablet preparation of oodium gentisato 1s giron by Iautor and assoolate (40). 


\section{PXPRIUTITNL}

Betere of gent1e10 eo1d or 2,5 dingdroxj benzo10 ac1d can be prepared e1ther with the earboxj110 noid funotion or with the phonolio funotion of the oompound. Eetera of the anino aloohole are of the riret tjpe, whoreas the eaterg of colde oonform to tho latter type.

Carboxyl10 aold estere maj be ejnthosized ae followas 1. Intereotion of an Ao1d Chloride and Amino Aloohol.

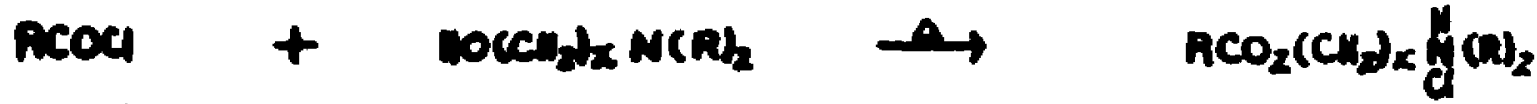

$R=$ Alipbatic or Aromatic

The general prooedure is to reat equimolar portions or the aold ahloride and the anino aloohol in an inert oolvent suoh as bensene. The hydroohloride of the enter usually preolpitate fron the roation mixture olther as an o1l or In orgatalilno form. If a colld, the product oan bo puriflod bj roorgotalisation from a eultablo solvent. Howovor, if the product 1s an 011, the colvent 18 removed under vaouum and the salt is enerally converted into its bace by use of alkal1. The equeous oolution is thon extraotod with othor eoveral times. The other 1s removed under vaouum, leaving the bae10 eater. Whenever poevible the eter is dietilled et reduoed proseure. Tho produot 1s then wolghod, plaoed in - sultablo colvent (1.0. - ther or bonzeno) and treatod with one equivalent of an anhraroua aloohol10 or o thereal solution of bydrogen obloride. Tho use or exoes hydrogen obloride, may doley or inbibit oryotalilsetion and roault in the 
soparation of an o1l whioh romaine as suoh inderinitely. Othor salta woh a tho sulfate, hydrobromide and citrato aty bo propared in a eimllar mannor (4l).

Ao1d. whioh oontaln additional funotional groups suoh ae aloohole, phenole and/or aminos oan be made into aold ohlorides only when these groupe are proteoted in the usual manner (1.0. formation of aotates or ojolic aobtals). After ostorfloation the protective groups on be removed.

8. Interaotion of an 1010 with a Chloralkamine.

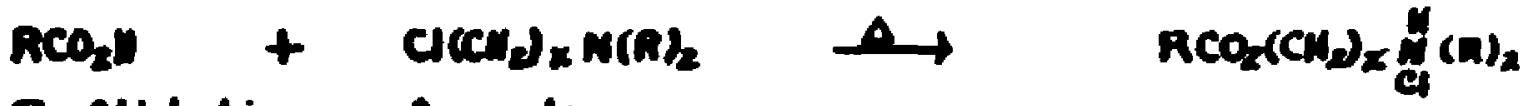
R-Aliphatic or Aromatic

Horonetein and Pahlioho (42) proposed this mothod for ejathoses of basio esters. Equimolar quantitios of a onboxjl10 ao1d and ohloralkamine are condensed in one of two waje. The oondeneation on be ourried out by mixing the halide with a loopropanol eolution of the aold and refluxing the mixture for coveral houra. The hydroohloride may preolpltate from the colvent and oan be purified bj reorystal11zetion, wang timea from the nome golvent. However, if the enit is aoluble in the eolvent, it is adrisablo to romove the eolvent, liberate the, eter bace with alkall and proceod ar under seotion 1 .

An alternate prooedure 1 s to add tho hallde to an alcohollo golution of the sold, remove the wloohol under reduced preasure and heat the rosidue 10 hours at $90^{\circ}$ to $100^{\circ}$. The gump nase obtalned oan be extraoted with acetone to remove 
the urreated antorials and excess solvont. The ealt of the aline whioh 19 insoluble remalns and 18 riltered off. The calt on be reoryatallised from altable solvont. The mothod 1. aultable for esterifioation of aolde conteining reactive groupe or eaterifiontion whore the nold ohlorides are inherently unstable or diffloult to propare (4)

3. Interaotion of the Sodium or silver salt of a Carboryl10 Aold and a Chloralkamine Hydroohlorido.

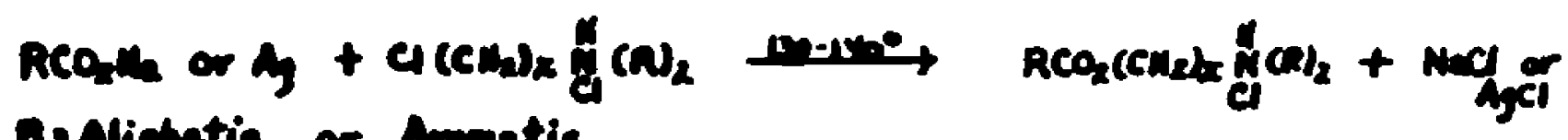
A-Aliphatic or Ammatic

Horenotein and Pahlioke (42) reaoted these materials in the abeenoe of a solvont. The ronotants were boated gonerallf to $130^{\circ}$ or $140^{\circ}$ for beveral hours. The mess was extractod with a euitable olvent while hot and the oompound orgetal21sed from the eolvent.

s. Reaotion of an Alrgl Boter with an Amino Aleohol.

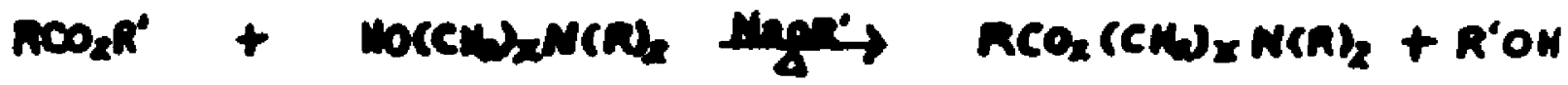
$R=$ Aliphatio or Arom atic $\boldsymbol{K}^{\prime}=$ Niphosie

Tho proose oonelste of heating the methyl or othyl oster of the eold with an exoess of the dialkyliminoalkanol, usually in the presenoe of a mall amount of sodium alkoxide, In auoh a manner that the lower bolling aloohol distila an it 1. dleplaoed. Prolonged hoating 1a required, therefore many unstable besio eotere oen not be prepared in this manner (43). 
5. Reaction of a Halogen Derivative with an Amine.

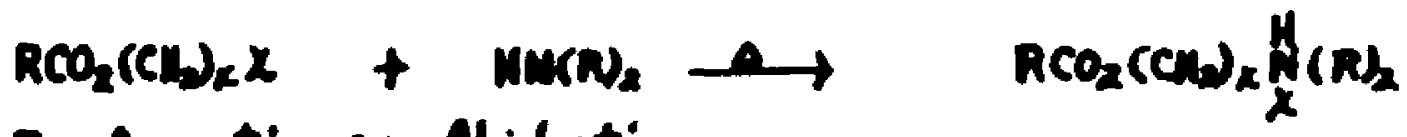
R. Anondic or Niphatic

Tho ronotion between ohloro-and bromoalkyl eatora and anines is of limited value beonues of low j10Id and ouperlorlty of other mothode (44).

6. Recotion of a Carboxy 110 Ao1d with an Aminoulcohol In the Pronenoe of a Catalyet.

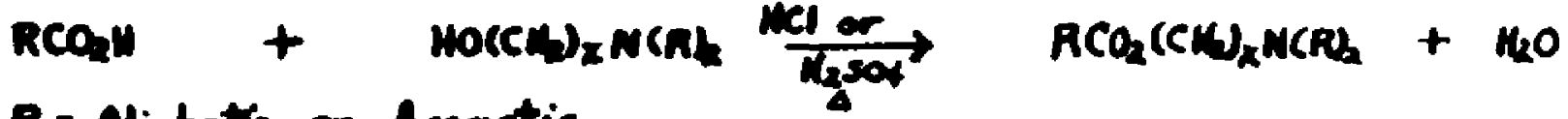
$R=$ Miphatic or Arometic

The aloohol 10 generally added in exoess to disaolve the aold whioh is generally a solid. As catalyst one oan employ elther canoou hrdrogen ohloride or conoentratod eulfurio aold. Tho excest aloohol 1s then romored under vaouus and the selt propared as in seotion 1 (45).

Tho experimental work performod by the author demonetrated thet enterifioation or gentisio ac1d with diethrlaninoethanol and diethjlaminopropanol took plaoe most eucoesefully and in bot jlelde by following the eocond prooedure. However, the halogen derivative of dimothylamino-thanol could not be found in the 11 toreture and the reaction did not jield the desired produote. The roeotion is good only for tortiary aloes, because anides or mixtures of andes and etere aro obtained mon seoondary or primary anlno loobols are ueed (46).

The f1ret prooedure wae atterptod by utilising gentiayl 
ahloride, but no reaulte were obtalned. The produetion of the aold ohloride of gentile aold without proteotion of the pbenol10 groupe 1s questionable although sellojl oblorido has been reported of Kopoteohn1 and Iadislaus (47), so woll as Wolerenatein $(48)$.

The roeotion of adium gentiale with the hydroohloride ealts of primary, seoondary and tertiary amino halldes did not Jield estere for ang of the aninos.

Direot enterifioation by interaotion of gontie10 ao1d and the anino aloohol, disolved in exoess of the amino aloohol, did not jield an ester upon addition or several drope of conoentrated alfur10 ao1d. The other mothods of eterifioation of gentielo aold woro not attompted.

lotere of phonolio runotione maj be propared in the rollowing manner. In the general oase, the roaotion 1 a between a phonol and an aold ohloride. Tho variations are in tho uee of colvent and oondeneing egent.
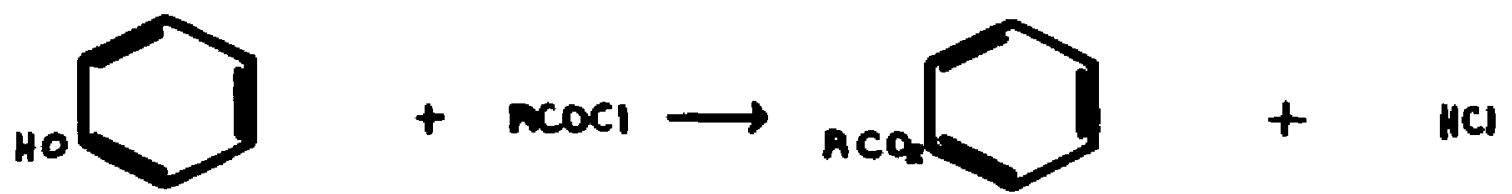

$R=$ Aliphatic or Amomatic

1. The Interaction of a Phenol and lold Chloride in Inort solvent. Equimolar portione or aold ohloride and phonol are aleoolved in bensene or other aultable colvent and onough pyridine added to oondense with the hJdrogon 
ohloride liberated. Tho solution,ohaken several times with dilute hydroohlorio aold, ronoves any oxoese pyridine. If the product 1s a col1d, it waj be 111 tored off and reorjotal11sed frov a sultable jolvent. However, if the produot remaine in solution the wolvent is generally romored under reduoed pressure and the mase 1 e maken woll with $5 \%$ sodium bloarbonete to romove the unreacted phenol and the exoese aold ohlor1de. The realdue is riltered and rooryatallized from sultable solvent (49).

8. Tho Interaction of a Phonol and a loid Chloride in Prridine. A mixture of equimolar portions of acid ohlorite and phonol are added to pyridine and the mixture hoeted on tho stean beth Irom 20 to 30 minutes. Whon the mixture is 0001 . It is pleoed in an 100 bath and 5 timos 1 ts volume of E\% sodiun bloerbonate added with oonetant otirring unt 11 the product orystall18ea. The sol1d 1s f1ltered, washed 1 th $5 \%$ sodiun bloarbonate and arled. Tho orude product may bo roorgatall1sed from a ultable wolvent (50).

3. The Interaotion or an Loid Chlorido and a Phonol in Aquooue Alkal1. (Bohotten-Bauman reaotion). Bquimolar portions of the phonol and coid ohloride are reactod in $10 \%$ sod1.u hraroxide. Tho phonol 10 dissolved in tho alkaline colution and the ao1d ohloride added with continuous etirring. The alxture is oooled sowly to roow tompereture and then in an 100 bath. Cold dilute hjaroohlorio ao1d is added unt1l atrongly ao1d. The proolpitate 1o rilterod and dried. The 
product on be purifled bJ dissolving it in aoe tone or aloohol and reproolpltating by adding wator. The prooese 1. repeated in the warm alvents to give groater purity. Howerer, final purification should be brought about by roorjetallization from a sultable solvent(5l).

Although the firat two proooduros were tried repeatedif wth gentisio aold and rarious acid oblorides, no rosult: oould be obtained. In the majority of cases both the gentialo ec1d and tho other acid wore reoovered. It appoars that only hydrolyale of the aoid ohloride took place.

The third prooedure jielded good rosults and noceptablo jlolds of the phonollo estera. Eeters or salloglio ac1d, b-aotyl-gentialo ac1d, diphenglaoet10 acid and diethylaoetio aold could not be obtained bJ this prooedure. It is poseible that the eold ahlorides of these ecide were not obtalnod.

Bach oeter ayntholized was analyzed in the following manner, when applicable, to determine 1 to structure and - lement oontent.

1. Phya10al Propert10a, 1.0. m10rosoop10 eppearanoo and solub121t5.

2. Stabli1ty in $\Delta 1 \mathrm{r}$ and Aqueous Modia.

3. Qualitative Elowental content.

4. Ferrio Chloride Color Test.

5. Kjeldahl Mitrogen.

6. Ionio Chlorine Titration. 
7. Carbon and H ydrogen".

Q. Noutral Rquivalent.

Q. Infrared speotrum.

The physloal propertios of each compound wore determined bj examination of the produot under the mloroscope and dotormination of 1ts rolativo solubility in various solvonts.

The stablilts of the oompounds in alr and aqueous solution was obsorrod during coreral wooke.

Qualitative olemental content was dotormined by the procedures of Shriner and Fuson (52).

The phenollo oolor tost, bj une of ferric ohloride T.S., was dotermined for each oompound.

Kjeldahl nitrogen was determined by the mlcro tookn1que (53).

Ionio ohlorine was determined by titration with standard -11ver n1trate, the Mohr Mothod (54).

Carbon and hydrogen analys is was done by Bll L1lly and Co. researob laboratories.

Modifioation of the atandard noutral oquivalent procodure was noceseary to obtein acourete molooular wolghts of tho aypthosized oarboxyllo ac1d ostor hydrochlorides. Howover, the molooular we1ghte of the phenol10 no1d esters wore dotermined in the ueual manner.

Only Diethylaminoethyl 6-aoetyl-gent1sa to hydroohlorido, diethylerinoe thy 1 5-bensoyl-gentieate hydroohlorlde and diethyleminopropyl gentisate hydroohloride, of the oarboxylic a 1 deter hjdroohlorides. 
The entere formod through the oarboxyl10 aold group were all tertiars amines, In the rorm of tholr hydrochlor1dea. Upon the t1tration of the compound with atandarized onrbonate froe base, the basio anines were roleased and buffer ajeteme wore establichod. Therefore, no sharp broak In the titration ourves could be obtained. The problem was to romore the balio aminos whioh wore partialis or completels water coluble.

The riret prooedure tried was to underlay the aqueous colution of the salte with ohloroform. Upon titration of the ants with base the amines passed into the ahloroform layer. Onis ralr reaulte were obtained, due to the fact that the partition ooefricient of the amines betwoen water and ohloreform wae not lerge enough. The aminea therefore, et111 exerted com erfeot on the pH roadings. The procedure poselbly oould be Improved by uso of an $1 \mathrm{mmisolblo}$ solvent that had a largor partition ooeffloleni for the aminos than obloroform vith wator, or by tho dotormination of tho puit1tion ooeffiolent of the amino. in wator and ohloroform and applying a oorrootion to the rovulting moleoular wolght.

$\Delta$ mothod that was found to g1vo good rosults was the deternination of the neutral equiralent of the base, inotead of the no1d. In this an exoess of etandard bave was added to 26ml. of a 50, aloohollo solution of the awine hydroohloride. Tho baslo amine wa l1berated. The exoese atandard alkall and the amine were then titrated $\mathbf{w}$ th atandard acid to jiold 
sodiu obloride and the ealt of the am1ne, reapootively. The ent1re titration was carried out under nitrogon to provont ar oxidation of the phonol in baglo eolution and aleo to prevent contamination by oarbon dioxide of the alr. A oharp break in the titretion curre was obtained at the ond point. good renults oan be obtained by une of $0.1 \mathrm{~N}$. elkall and 0.1 H. aold. Moroburettes are of value oapeolally whon amall eamplea are being titrated.

Care chould be exerolaed to standardize the base and aald in so, aloohol whioh 1a neutral to phonolphtalein. Therefore, al though the $\mathrm{pH}$ roading may not bo aocurate, a compared to aqueous solution, the ahange of $\mathrm{pH}$ per volume of acid w111 be the same. However, alenk should be obtained for $26 \mathrm{ml}$. of $50, a 100 h o l$ to determine the amount of aold neoded to return the aloohol to a pH oqual to the pH at the ond point of a titration of a sample.

Saponifioation of the estera of tho oarboxyl10 a old was attomptod in alooholio alkal1, but poor roults woro obtalned. More alkall was ooneumed upon rofluxing tho oster with alooholle alkali than bJ allowing the lngredients to sot In the oold, but the oonaumption did not ropresent an oven number of equivazente of eikali. It 1 o beliered that due to the rapid axidation of phenole, and more partioularis quinones, In alkal1 modia. good saponifiontion numbers oan bo obtalnod onls if both phonol10 group are blooked. The author at temptad to make the diacetjl and dimethoxy derivatives of gentieio 
21

e01d, and found it vory diffloult to aoetylato or methylate the number 2 position of the acid. Therefore, no saponifiontion values wore obtalned.

$\Delta 21$ melting pointe were obtained by ueling the molting polnt beth apparatus. The thermometor was allbratod over the m. P. range of $50^{\circ}$ to $286^{\circ} \mathrm{bJ}$ meane of elght pure oompounde. The correoted m.p. refers to oorreotion for emergent otem. 
New Betere of Oent1et10 $101 \mathrm{~d}^{2}$

D1ethrlaminoethrl gentiento Hydroohlor 1de*

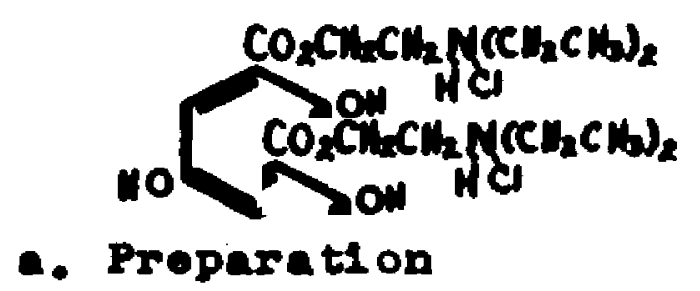

Diethjlaminoothjl gent1sato hydroohloride was prepared by the interaotion of the halogen derivative of diethylamino- thanol and gentielo ao1d; tho Horonstoin and Pahliche nothod (42).

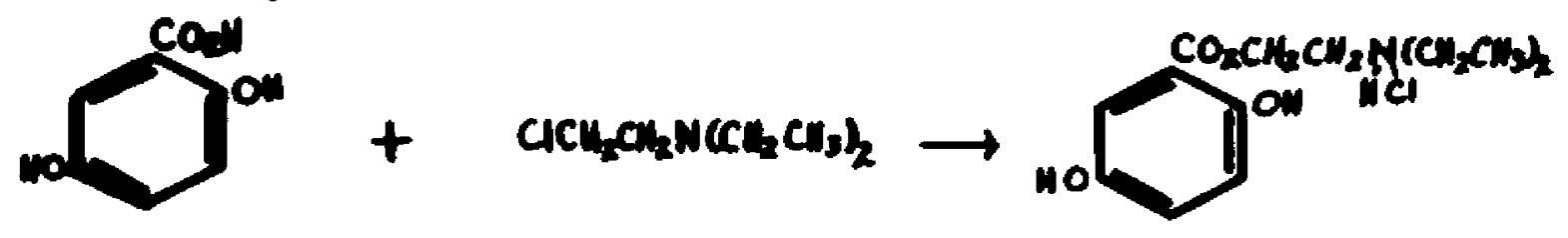

Diethylaminoethyl onloride was prepared by two mothods. The flret procodure was as followa (55):

D10thjlaminoe thanol, 43 B. $(0.37$ mole), was addod to $50 \mathrm{ml}$. of bensene oontainod in a three nook, $250 \mathrm{ml}$. flask, In the hood. Thlongl ohloride, 115.9 g. (0.97 mole), was plaood in a paratory funnol and added slowly with conatant -tirring to the benzeno-amino aloohol mixture. Thel roaction was at followe:

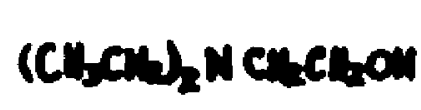
$\left.+\quad \mathrm{SOCH}_{2} \longrightarrow \mathrm{CH}_{3} \mathrm{CH}_{2}\right)_{2} \mathrm{Cl}_{\mathrm{CH}}^{N} \mathrm{CH}_{2} \mathrm{Cu}_{4} \mathrm{Cl}+\mathrm{SO}_{2}$

Tho reation was rlolent and etrongls exotherm10. Aftor add1tion of all the thionyl ohloride the produot was refluxed i hours. The mixture was derk brown in oolor and contained

\footnotetext{
Trev Compound.

180e pages 61-79 for proor of atrue ture.
} 
a roluminous anount of sol1d. The exoese thionyl ohloride and the solvent were romored under reduoed preseure. The reeldue wae heated to $180^{\circ}$, $\operatorname{sor} 2$ houra at the reduoed presaure. The rosidue wes then diseolved in water and tho solution was filtered. The filtrato was placed in the refrig erator for several hours. Tho oold solution was made strongif alkaline with 40,60 sium hydroxide, until the proolpitation of a light brown waterial subsidea. The reaction was a. Fol10was $\left(\mathrm{CH}_{3} \mathrm{CH}_{2}\right)_{2} \mathrm{NCH}_{2} \mathrm{CH}_{2} \mathrm{Cl}+\mathrm{NaOH}+\mathrm{H}_{2} \mathrm{O}$

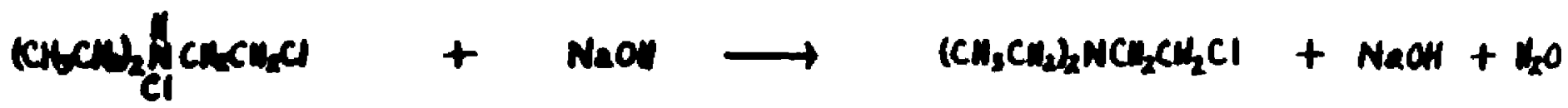
The Elxture was extraoted with noveral portions of other until only a light jollow aqueoua solution romained. Aftor romoral of the wolvent bJ evaporation, the romalnder was alet1lied to j1eld a wilky solution of atrong amoniacal odor, b.P. $68-70^{\circ}$ at $30 \mathrm{~m}$.

Rediatiliation jlelded 30.0 g. $(60.8 \%)$ of a olear,

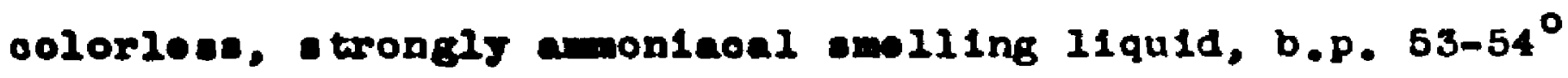
at $28=$

The sooond prooedure (56) conseted in pleoing $72.5 \mathrm{~B}$. $(0.61$ mole) of thionjl ohloride in a three nook flask prorided with a etimrer, reflux oondeneer and dropping funnel. The Ileck was placed in an 100 bath in the hood until the 11quid was thoroughly o001ed. Dle thylaminoe thenol, $52.2 \mathrm{~g}$. (0.45 mo10). wes added dropwise with conetant etirring to the 
oold thlongl obloride. After 211 the aloohol was added the produot was otirred an additional hour at room temperature. The entire oontents of the rlak wa tranaferred to a $1000 \mathrm{ml}$. beaker mioh oontained $850 \mathrm{ml}$. or absoluto aloohol. The solution was heated to a gentle boll for 1 hour or unt1l gaces oeased to be evolved. The volution was filtered hot and pleoed in the refrigerator over night.

Tho proolpitate was filtered and dried. The orude ylold of dlethyleminoethyl ohloride hydroohloride was $52 \mathrm{~g}$ ( $(68.9 \%)$

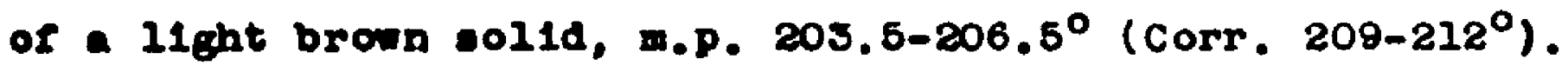

$\Delta$ leas pure fraotion was obtained by oonoentrating the filtrate to $1 / 3$ tho original volume and rooovering the proo1pltate. The Jield wae $15.72 \mathrm{~g} .(20.0 \%)$ of the lose pure,

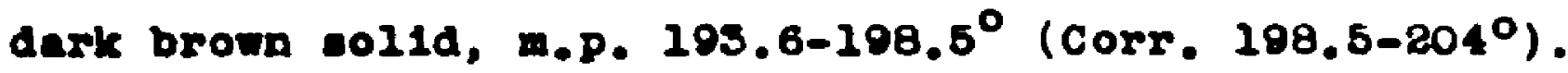

The total orude gle1d was $67.72 \mathrm{~B}$. $(89.8 \%)$.

D10thylaninoethjl ohloride hjdroohloride, $30 \mathrm{~g}$. $(0.17 \mathrm{~mole})$, was pleoed in a $1000 \mathrm{ml}$. beaker and $10 \mathrm{~B}$. of oruahed 100 added. The boaker wae plaoed in an 100 bath and $40 \mathrm{al}$. of ether added. men the beaker and oontents were 001d, the mixture was made atrongly alkaline with $40 \%$ sodium hy croxide. The extration was cerried out several timed. Tho - thereal eolution of the belide wea dried over drierite for sereral houre. After the remal of the solvent bJ evaporat1on, the roelning rod oolored oll wat distillod to ylold 17.8 6. (74.1,6) or a olear, colorlese, trongly amoniacal 
owelling 11qu1d, b.P. $44-46^{\circ}$ at $13 \mathrm{~mm}$. (57).

Burther (B8) desaribes a mothod for the liberation of the basio bal1de from the hydroobloride bJ addition of rlaked eodiu hrdroxide to the cit. The mixture wan atirred and the hallde alet1lied under roduoed preseure. The hellde was dried over potaselum oarbonato. However, it was found that the J1eld was poorer and a 20 as pure compound was obtained then the extraotion prooedure.

D1e thjlaminoethyl onloride, $6.6 \mathrm{~g}(0.06 \mathrm{molo})$ was added to an aloohol10 solution of $7.4 \mathrm{~g}$. (0.05 molo) of gont1s10 cold (Dolta Chomionl Corporation). Hoat was ovolved and the solution wes chaken $t 111$ cool. The aloohol was romoved under reduoed proseure. The gumm resldue was hoated 2 hours at $80^{\circ}$ and 10 houre longer at $100^{\circ}$.

seetone was added to the gumy rosidue and disoolved a portion of 1t, loaving a rloooulant, white proolpitato. Tho preolpltate wa filtered and the dried product represented a orude jield or 9.6 B. $(66,16)$, m. D. $140-148.5^{\circ}$ (Corr. 143151..$\left.^{\circ}\right)$.

Tho orude etor ant, 9.18 b., wae dissolved in water and $5.36 \mathrm{se}$ or sodiun oarbonate $(67.2 \mathrm{ml}$. of $5 \%$ codium onrbonete) added. A roluminous inite, olouds solution roultod. Three $40 \mathrm{ml}$. portione of other vere uaed to extraot the banlo anine from the equeous moda. To the ethereal oolution of the

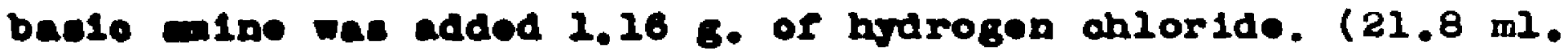
of 1.4616 H. eloohollo hydrogen ohloride eolut1on). The 
J101d was 6.7 s. $(46,3,5)$ or a wh1te, heary s011d, m.p. 149.5-161 ${ }^{\circ}$ (Corr. $\left.168.5-154^{\circ}\right)$.

Tho diethjianinoethjl gentivate hraroohloride wes again ade bas10, extraoted with ether and reprooipitated an the

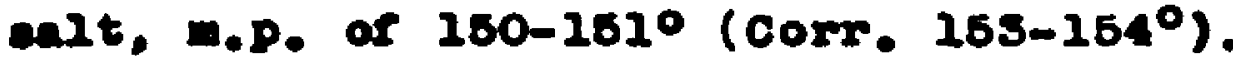

An alternate prooedure deseribed by the same au thora was ac followe (42):

Gentislo sold, 5 g. $(0.03$ mole) was diasolved in $50 \mathrm{ml}$. of leopropanol and to tho solution was added $4.1 \mathrm{~g} .10 .03$ wole) of diethylaminoethjl ohloride. The mixture booame alightif warn upon ahaking. Whon the wixture oooled, it was refluxed i houre. Upon oooling to roon tomperature, oryotal11sation oocurred. The f11tered and dried produot repreaented arude jleld of $2.8 \mathrm{~B} .(23.5 \%)$ or a wite, rlooculant preolpitato, D.p. $140-170^{\circ}$ (Corr. 143-173.5\%).

Tho eator upon roorjotallisation from 1eobutanol jielded 1.88 6. $(10.8 \%)$ of a whito, oryataline colid, w.P. $161,8-188.8^{\circ}\left(002 x \cdot 154-166^{\circ}\right)$.

The produot ahowed no ohange in molting point rango after It wo dried in the Abderhalden Drging Platol for 3 hour: at $100^{\circ}$ and $1-3 \mathrm{~mm}$. 


\section{b. Properties}

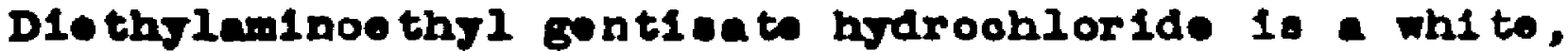
gralny powder. Colorlene pletos are seen under miorosop10 eacuifioction won the compound is purified by the reprooip1tation w thod. However, when roorjetali1zed from 1 sobutanol 1t appoare to be a parking, orgatallino volid. M10rosooplo oxamination rovealod large, oolorloas plates. The oompound has a oweet aromat10 anoll.

Tho alt 1. very soluble in water, absolute aloohol, 95, aloohol, d12ute aloohol, butanol, hot loobutanol and pjridino. It 1a partiallJ ooluble in 1sopropanol and incoluble in ohloroform, carbon tetrachloride, toluene, bensene, ethjl aoetate, other, aotone, petroleum ether, skellfo0lve B \& $C_{\text {, d }}$ doxano and oold 1sobutanol.

The elid 10 etable in a1r. The compound 1s unstablo in aqueoue oolution turning from a colorlose to a brown solution In coveral daje, and upon adding alkal1, the oolor ohange takes place in neveral minutos.

Qualitative eloment analjels shows nitrogen and ohlorine to be present.

The forrio ahloride teet 1o positive. (blue-purplo in aquecue eolution).

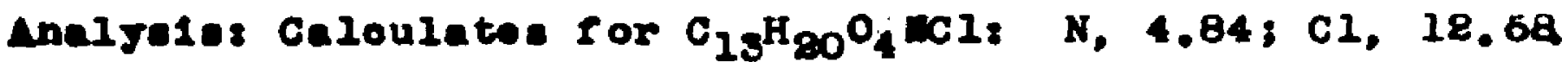
Founds $1,4.73,4.64, \mathrm{Cl}, 18.68,18.65$.

Heutral Equivalent. Caloulated for $\mathrm{C}_{13} \mathrm{H}_{20^{\mathrm{O}}} \mathrm{Ns}^{\mathrm{s}} 263.30$ Pounds 260.98, 253.30. 


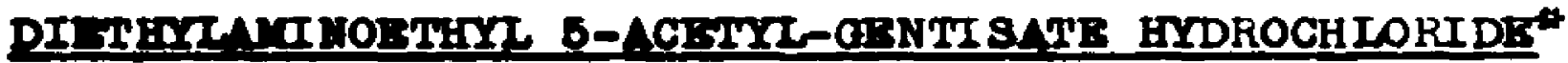

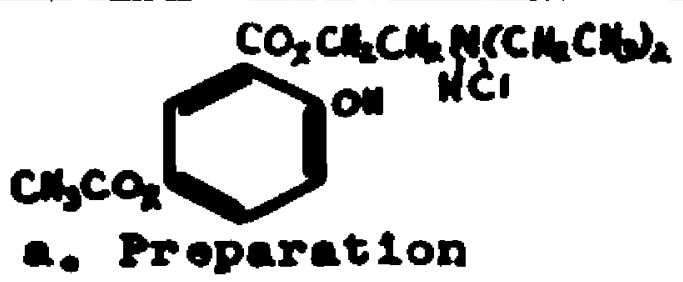

D10thjlarinoethyl b-aettjl-gent1sate hjdrochloride wae prepared by the interaotion of 5-aoetyl-gent1e10 ac1d and d1 thylaminoe thyl abloride (42).

6-aootyl-gent1.10 ao1d was proparod by two proooduros. Tho firet oone1sted of the interaotion of gontlalo aold with aotio anhydr1de, while the sooond mothod employed aootyl ohloride as the aootylating agont.

The firat prooedure wa oarriod out as follows (59): To $300 \mathrm{ml}$. of $2 \mathrm{~N}$. oodlum hyaroxide, heatod to $60^{\circ}$, was added 50 B. (0.20 mole) of gent1s10 acld. When colution was ocoplete, $39 \mathrm{~g} .(0.38 \mathrm{mol0})$ of acotlo anhydride was added and the solution was stirred t1ll o001. The ontiro rlask and oontente wore plaoed in an 100 bath t1ll cold. Cold d1lute hydroohlor10 aold was thon addod and a croamy, whito proolpltate formod. The proolpltato was rilterod and driod. The f1ltrate was made more etrongly ac1d with oonoentratod hydrouklorio ao1d ta insure preolpitation or all the 5-nootylcont1010 a.1d. The total y101d was $35 \mathrm{~g} .(91.0 \%)$ of a $11 \mathrm{ght}$

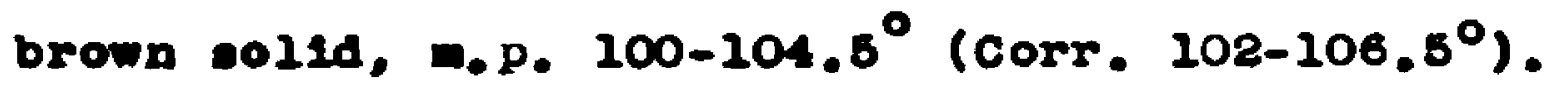

The aoptrlated compound was roorjatallieed from toluono 
jlelding 24 G. $(63.0,6)$ of a white sol1d, w.p. 131.5-132. $2^{\circ}$ (Corr. 133.5-134. $8^{\circ}$ ).

The equatione for the renotiona involved in the above proosdure are at followa:

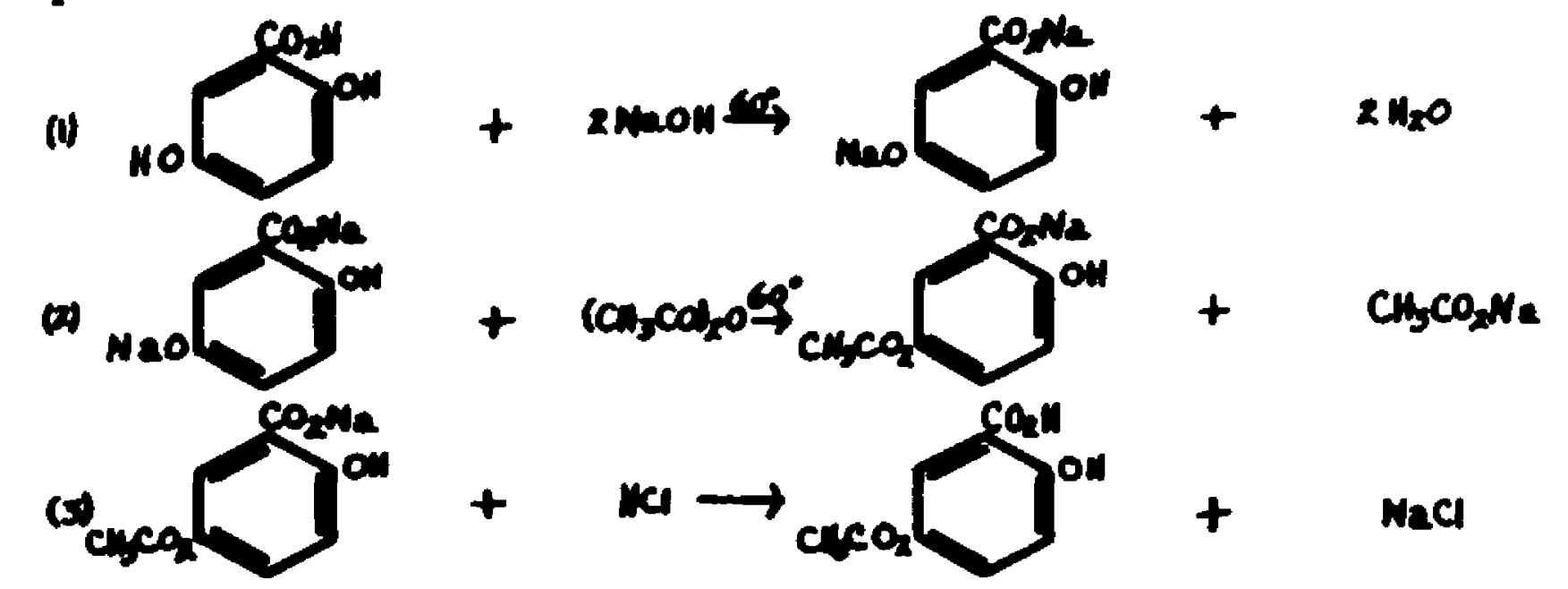

The cooond wethod for the proparation of the 5-acetyl derivative ueed aoetyl ohloride (60).

soetyl ohloride was prepared by dropwlse addition of $80 \mathrm{~B} .(0.58 \mathrm{~mole})$ of phosphorous triohloride to $100 \mathrm{~g}$. $\left(1.66\right.$ wole) of gleolel a00t10 a01d. $3 \mathrm{CH}_{3} \mathrm{COCl}+\mathrm{H}_{3} \mathrm{PO}_{3}$ $3 \mathrm{CH}_{3} \mathrm{CO}_{2} \mathrm{~N}+\mathrm{PCl}_{3} \longrightarrow 3 \mathrm{CH}_{3} \mathrm{COCl}+\mathrm{H}_{3} \mathrm{PO}_{3}$

The roeotion rlask was plaoed in an 100 bath and was oooled $1 / 2$ hour. After hoting at $50^{\circ}$ for 1 hour the aoetyl ohloride was distillod from the mix ture ylolding $44.2 \mathrm{~g}$. $(35.0 \%)$ or a oolerieas atrongly Irritant smolling liquid, b.P. $80-55^{\circ}$.

Tho aotjl ohloride was reoted with gentiolo acid in bae10 mod1a, 1.0. Sohotton-Bauman roaotion, but very poor j1eld of the 6-eoetyl-eent1s10 ciold was reoovered. The recotion wa not invertigetod further beocuse of the better 
jleld obtained bj the use of noetio anhjdride.

(1)

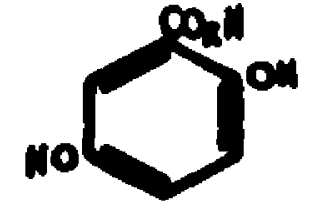

(1)

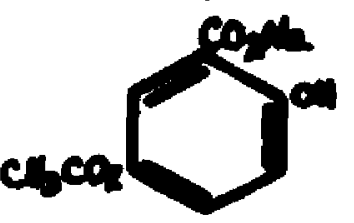

$+$

cr.soca

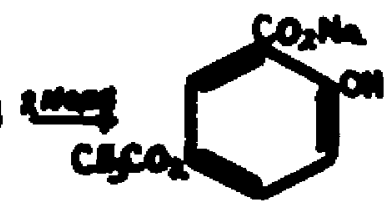

$+\mathrm{MaO}+\mathrm{H}_{2} \mathrm{O}$

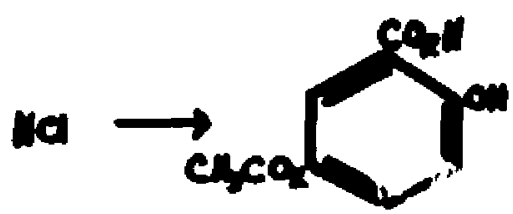

$+\mathrm{mad}$

D10thjlaminoethyl 6-eoetyl-gent1a10 ac1d hydroohloride was prepared suocesafulig by the samo two procedures which wore ueed to propare diethylaminoothjl gentialo aold.

Bquinolar portione of tho hallde and acld were heated for 2 hours at $80^{\circ}$ and thon 10 more houra at $100^{\circ}$. A orude

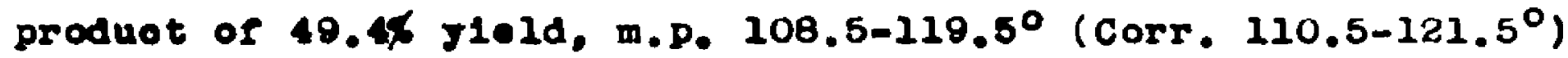
preolpitated when the mase wae mixed with aootone.

Purifloation of the orude product was attomptod by diacolving the oolid in wator, adding an oquivalont portion of sodiur carbonate, extraoting soveral times with other and repreolpitating the alt by adding aloohollo hydrogen ohloride to the ether. Howerer, an 011 weparated and oould be oolidifled onlJ by o00ling. The gleld was about $20 \%$ of a whito s011d, D.p. 218.6-126.5 (Corr. $120.5-128.5^{\circ}$ ).

Upon ropoating the renotion, and rooryetallizing the orude ocmpound Irom loopropanol, the jield was $5.9 \%$ of a

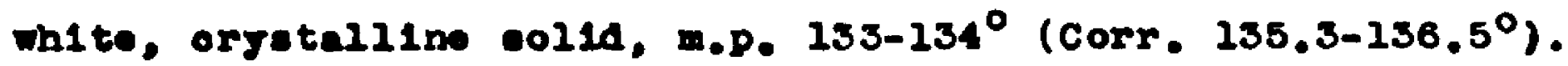

Much better wucoese was obtained whon equimolar portion of diethjleminoethjl ohloride and 5-aoetyl-eentialo aold ware refluxed in leopropanol for 8 houra. Opon oooling the solu- 
tion jielded 82.8\% or a mito, orjatelilno volid, m.p. $106.5-130.5^{\circ}\left(\operatorname{corr} .108 .5-133.0^{\circ}\right)$

Tho ostor was reoryetallized 5 timo from 1sopropanol jlelding 44.8p of a vb1to, needle-11ke sol1d, m.p. 133.5$134.6^{\circ}\left(\operatorname{corr} \cdot 136-137^{\circ}\right)$.

The oompound ahowed no ohange in melting point when it was dried in tho Abdorhalden Drying Platol as provioualy deseribed. 


\section{b. Propert10e}

D10 thylaminoethjl b-aoetgl-gentleate hydroohlor 1de, when reorjotallised from 1sopropanol, appeara under the miorosoope as oolorlese, floooulant volld oonaloting of long, thin, oolorlese modles. To the naked oge the oompound appears as a wito, rlooculant, reathery powder. Tho oster has a aweot, aromat1o anol1.

The ealt is vory oluble in weter, absolute alcohol, 95\% aloohol, ohloroform and hot 1sopropanol. It is partialis coluble In butanol, 1sobutanol, other and acotone, but inooluble In othyl acotato, oold 1,opropanol and potroloum - ther.

Tho dry ealt is able in a1r, howevor, in aquoous solut1on It turne brown in several dage. The oolor ohange takes place in several minutes timo in alkaline modia.

Qualitativo element analyalo showa nitrogen and ohlorino prosent.

The ferrio ohloride teat io positive.

Analsales Calouleted for $\mathrm{C}_{15} \mathrm{H}_{22} \mathrm{O}_{5} \mathrm{NCl}$ : C, 54.30; $\mathrm{H}, 6.68$; 1. 4.22; Cl, 20.69. Found: $0,54.41 ; \mathrm{H}, 6.78 ; \mathrm{N}, 4.21$ and $4.13, \mathrm{Cl}, 10.60$ and 10.64 .

Heutrel equiralents Caloulated for $\mathrm{C}_{16} \mathrm{H}_{22} \mathrm{O}_{5} \mathrm{~N} 2295.33$. Pounds 301.61, 301.79. 


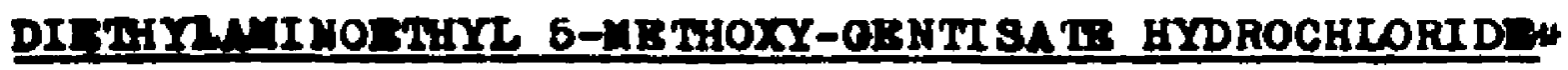

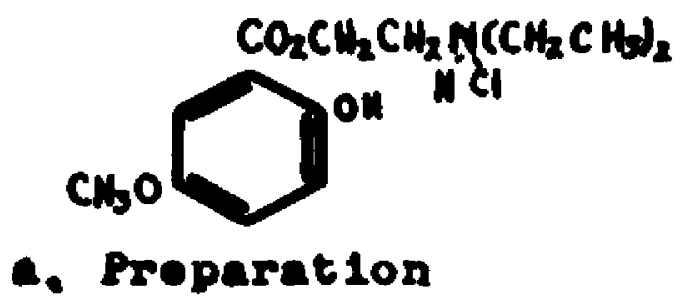

Diethjlarinoethyl 6-nethoxj-gentleate hydroohloride was produced by the reaction of diethylaminoethyl obloride with 8-wothoxy-gent1e10 aold (48).

The 6-eothoxy derivetive of gentilic eo1d was propered by d1seolving $20 \mathrm{~g} .(0.13 \mathrm{mol0})$ of gont1810 acid in $100 \mathrm{ml}$. of 10, hrdwoxide and adding $44.28 .(0.35$ wole) of dinethyl sulfete. The elxture was shaken 30 minutes during inloh there wae atrong evolution of hoat. The alxture was roflused 1 hour. The resulting aqeous $=1 x$ ture was acid and wer ade trongly alkaline with $20 \%$ eodiug hrdroxide. The heterogenous alxture wae refluxed for another hour. At this polnt the alxtare we alkeline or was ade alkaline as before and the refluxing ropetod. The alxture was coldifled with dilute hydroohlorio eold and oooled.

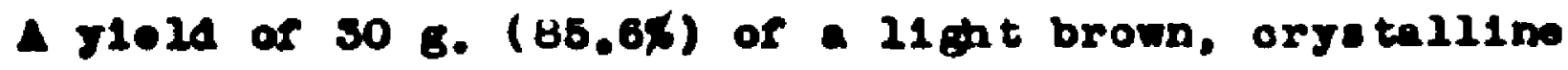

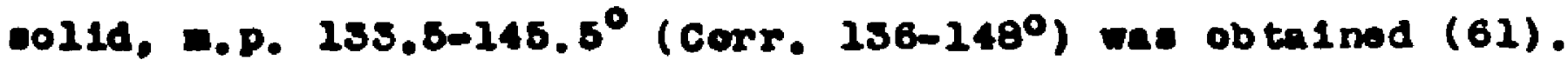
The wothyl ther wa rooryatallisod from water to jiold

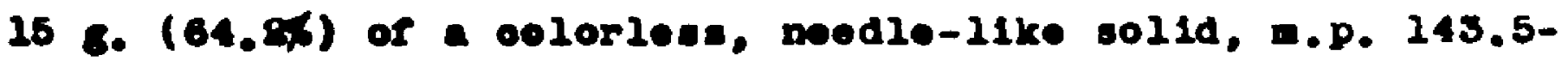
$144.8^{\circ}\left(\operatorname{Corr} \cdot 146-147^{\circ}\right)$. 
The roeotione involved in the proparation of 5-methoxygent1e10 no1d were as rollowes

a)

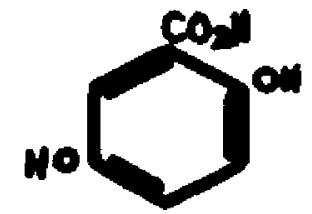

(a)

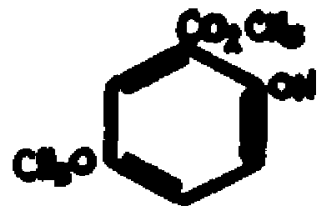

$\boldsymbol{\theta}$

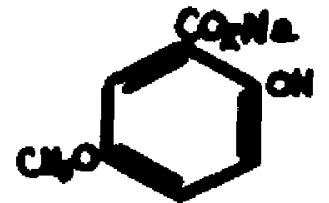

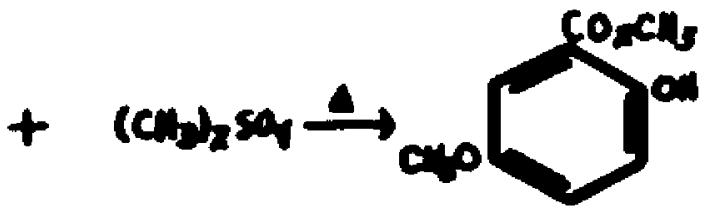

$+\quad \mathrm{H}_{2} \mathrm{SO}_{4}$

$+\quad \mathrm{CH}_{5} \mathrm{OH}$

NaO

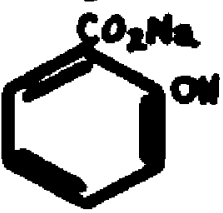

$\cos n$

$+\mathbf{M C}$

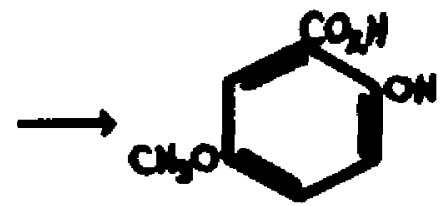

$+\quad \mathrm{NaCl}$

D10thylaninoethyl 5-wo thoxy-gentisate hydrochlorlde was formed by the reaction of the halogen derivative of the amino aloohol and gentialo ao1d in absolute aloohol. The aloohol was romored under reduoed presesure and the mixture heated for 2 hour: at $80^{\circ}$ and then 10 additional hours at $100^{\circ}$. Upon orjetallizetion, from 1sobutanol, a jiold of $92 . \% \%$ or a swoot

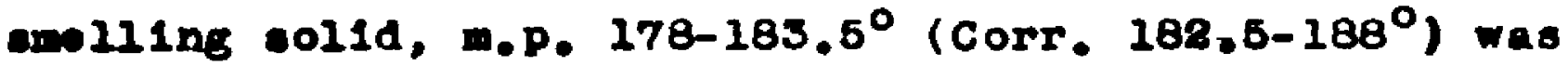
obtalnod.

Koorsetallisation of the compound from loobutanol, 3 time, Jlelded $68,0,6$ or a white, oryotalline volid, m.p. $188.3-183.0^{\circ}$ (corr. $186.8-187.5^{\circ}$ ).

Tho compound was arled in the Abderhalden Drying Pistol as previouelf desoribed and no ohange in the molting point wea not1ood. 


\section{Propert1ee}

D10 thylaminoe thyl 5-we thoxy-gentlate hydroohlor 1de is a 11ght brown, or colorlese, orjatall1ne sol1d. It appears as 2er6e, oolorless noedles under the miorosoope. The compound has a owoet, aromat10 ame11.

The ant 1s coluble in water, absolutc aloohol, 95\% aloohol, dilute aloohol, chloroform, toluene and hot lsobutanol. It 1s partially soluble in 1aoproponal and other, but Insolublo in aectone and oold isobutanol.

The anlno-eater 10 table as a solid. However, an aqueour solution is unetable, turning brown in several days. The oolor ohange 10 greatlj hastoned in alkaline solution.

analye1. for the element content of the compound shows nitrogen and ahlorine to be prosent.

$\Delta$ positiv tont 1 obtained with forric ohloride.

Analge1 as Caloulated for $\mathrm{C}_{14} \mathrm{H}_{22} \mathrm{O}_{4} \mathrm{NCl}$ N, $4.61 ; \mathrm{Cl}$, 11.67. Found: $1.4 .46,4.41, \mathrm{Cl}, 11.70,11.55$.

Houtral equivalents Caloulated for $\mathrm{C}_{14} \mathrm{H}_{21} \mathrm{O}_{4} \mathrm{~N} / 267.32$. Found 888,39, 270.31. 


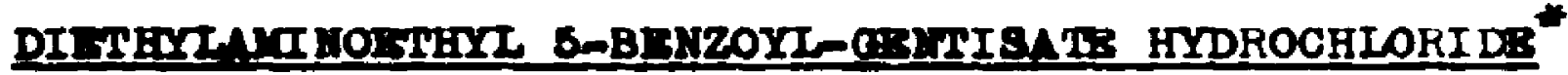
$\mathrm{CO}_{2} \mathrm{Cl}_{2} \mathrm{Cl}_{3} \mathrm{~N}\left(\mathrm{CH} \mathrm{CH}_{2}\right.$

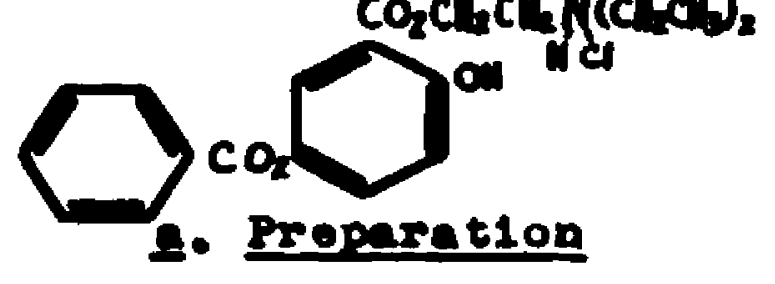

D10 tropaninoethyl b-bensojl-gentiente hydroohloride wae formed by the sav roaotion as the other carboxyl10 acid etor hydroohlorides of gent1a10 ao1d (42). b-bonsojl-gent1a10 ao1d was propared bj the sohottenBauman reaction between bensojl ohloride and gentialo aold (ei). The jield wae 84.2\% of a white, flooculant sol1d, m.P. $166.8-171.6^{\circ}$ (Corr. $170-175^{\circ}$ ).

Opon reoryatallisation of the compound from water, a

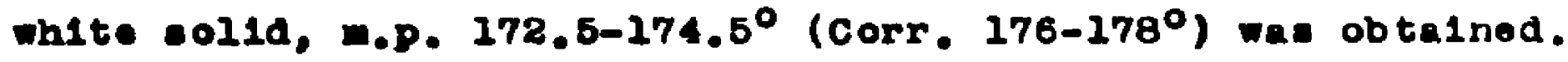
The eolld wae reoryetallized twioe by dissolving it in hot aoetone and ading water till the solution was oloudy. Upon oooline, a orgatal11ne col1d, m.p. or 178-179 (corr. 181,8-188. $0^{\circ}$ ), proelp1tated.

b-bonsojl-gent1sio aold and diothjlaminoothyl ohloride were reaoted in equimoler portione in 1sopropanol. The solution we refluxed 4 houre and wae $00010 d$ to $\mathrm{j} 101 \mathrm{~d} 77.6 \%$.

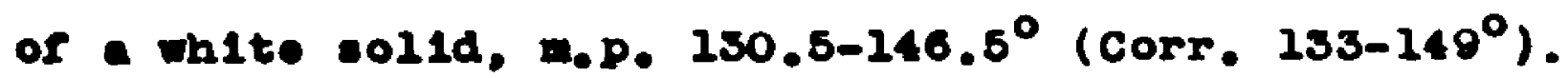

The oompound after 3 reorjatelileations from 1 eopropanol, jlelded 3.1 6. (55.15) of a mito, floooulant colid, m.p. 153.0-154. $0^{\circ}$ (0orr. 156.5-157.6 $0^{\circ}$ ). 
The oompound was dried in the raouum oven at $100^{\circ}$, 10-15 . for 13 hours. The melting polnt was the wame. 


\section{b. Properties}

D10 thylaminopthyl 5-benzoyl-gentisate hydrochloride is wite, flooculant powder. Under the mlorosoope, it appears to bo long, thin, oolorlesa noedles. The oompound 1s odor10a.

The alt 10 soluble in water, absolute aloonol, 95\% 10ohol, dilute alcohol, ohloroform, hot loobutanol, hot 1sopropanol and hot toluene. It is partially solublo in - ther and Inooluble In oold 1sobutanol, oold 1sopropanol and oold tolueno.

The product 1: atable in air, when drg. However, it turne brown in aqueous solution within several days. The ohange or color takes plaoe within soverel minutes in alka11ne eolution.

The qualitative elemont oontent is found to be nitrogen and ohlorine.

The phonolio teat with forrio ohloride 18 positive. Analjales Caloulated for $\mathrm{C}_{20} \mathrm{H}_{24}{ }^{\circ} \mathrm{NCI}$; $\mathrm{C}, 60.85 ; \mathrm{H}, 6.14$; N, 3.56; Cl, 9.00. Found : C. 60.40; H. 6.41; N, 3.45, 3.40; C1. 8.98, 8.95.

Noutral equiralonts Galoulated for $\mathrm{C}_{20} \mathrm{H}_{23^{\circ}} \mathrm{O}^{\mathrm{N}} \quad 357.39$ Found: 357.10, 354.38. 
DIFYHLNMINOPROPYL OENTISATS HYDKOCHLOKIDE

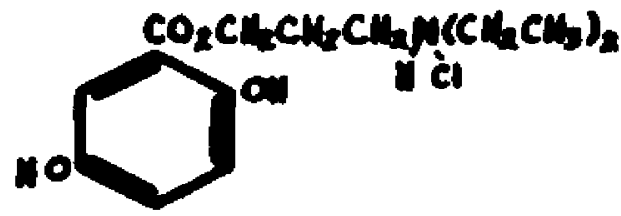

‥ Prepretion

D10 thylaminopropyl gentiate hydroohloride was prepared by the interaction of diethylaminopropyl chlorido and gent1e10 ao1d (42).

Diethylaminopropyl ohloride was prepared from the alcohol. A solution of 52.33 8. (0.43 molo) of 3-diethylamino, 1-propanol in $86.66 \mathrm{ml}$. of anhydrous ohloroform was added, dropw1se, to solution of $96.66 \mathrm{B.}(0.81$ mole) of thionyl ahloride in $400 \mathrm{ml}$. of anhydrous chloroform. The reaction was oontrolod bJ cooling the flask. After the reaction had oooled, the mixture was refluxed 3 hours. The solvent and exoess thlongl ohloride were then removed under reduood preseure, loaving a brown-black residue.

The eolld was plaoed in a boaker in an lce bath. Enough - ther was added to oover the solld and then oold, $40 \%$ sodium hyaroxide was added. The aqueous solution of besic amine was extracted 3 times ith ether. The 11ght-brown othereal oxtraot was dried over drierite aeveral hours.

After romoval of the solvont, the romainder was distilled to j10ld $47.0 \mathrm{~g} .(78.0 \%)$ of a colorleas, trongly ammoniaoal awe111ng 11qu1d, b.P. $93-97^{\circ}$ at $26 \mathrm{~mm} .(63)$

u equimolar portion of diethylaminopropyl ohloride wae 
added to an 1sopropanol colution of gentisic aold. The solution was refluxed 6 houra, and oooled.

After eraporation of the 1sopropanol, the sem1-0011d was mixed with eoetone and a jeld of $37.0 \%$ of a wh1to $0011 d$, w.P. $163.5-169.5^{\circ}\left(\operatorname{corr}, 166.0-172^{\circ}\right)$, was obtalnod.

The compound wes reoryetallized from loobutanol to gleld $24.5 \%$ of a wh1to, oryataline sol1d, m.p. 171.7-172.7 (Corr. 174.2-175.2 ${ }^{\circ}$ ).

The molting point remalnod constant whon the oster was driod in the Abderhalden Drying Piatol in the same manner as previously desoribed. 


\section{b. Propert10e}

D10 thylam1nopropyl gentleete hydroohloride 1s colorless, orgetalline needles. Under the mleroscope 1 t eppears to be long, thin, oolorlene oryetele.

The hydroohloride 1s soluble in water, absolute aloohol, 95\% aloohol, dlluto aloohol, lsopropanol, ohloroform and hot 1sobutanol. It 1s insoluble in acotono and cold 1oobutanol.

The dry produot is stablo in alr, but in aqueous solution it darkona in sovoral days; the time 1s docreased to coveral minutes in alkeline modia.

The anelysis of tho oompound for olements shows nitrogen and ohlorine.

The forrlo ohloride teat shows a phenol to be present. Analys1s: Calouleted for $\mathrm{C}_{14} \mathrm{H}_{22} \mathrm{O}_{4} \mathrm{NCl}$ C, 55.35; H, 7.30; $\mathrm{N}, 4.61 ; \mathrm{C1}, 11.68$. Found $8 \mathrm{C}, 55.45 ; \mathrm{H}, 7.42$; $x, 4.73,4.57 ; C 1,11.76,11.84$.

Noutral equivalont Caloulated for $\mathrm{C}_{14}{ }^{\mathrm{H}} 21 \mathrm{O}_{4} \mathrm{~N}: 267.32$. Found 264.98, 266.01. 
DIETHYTMUI MOPROPYL 5-ACETYL-GENTI SATE HYDROCHLOFIDF"

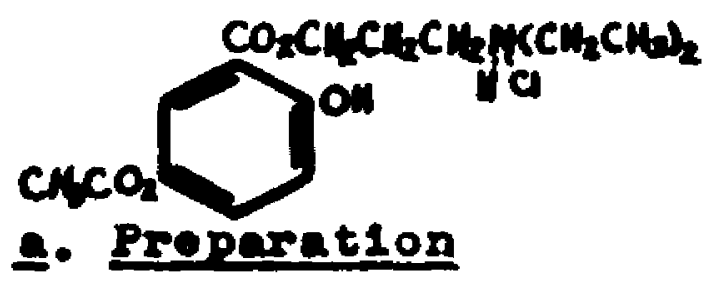

D10thjlaminopropjl Basoetgl-gent1eate hydroohloride was propared by the Horenote1n and Pahliohe reaction (42). Diethylam1nopropjl obloride and b-aoetjl-gent1:10 ac1d wore prepared at proviouely desoribed. The cold was dissolved in 1sopropanol and an equimolar portion of hallde was addod w1 th oonstant shaking. The mixture was refluxed 6 hours and was ooolod to roce temporature. No preolpltation took pleoe. Aftor evaporation of the 1sopropanol, the gumen residue j1elded 35.5\% or wh1 to col1d, m.p. $152-153.5^{\circ}\left(154.5-156^{\circ}\right)$, upon addition of thyl acetate.

The produot wa rooryetallieed 3 t1mos from toluone to J101d $80.0 \%$ of wh1to, floooulant sol1d, m.p. 157.0-157.5 (Corr. 160.5-161 ${ }^{\circ}$ ).

Tho molting point remained oonstant whon the compound wae driod in the Abderhalden P1atol as outlined for the procoding oompounds. 


\section{b. Properties}

D10thylaninopropjl 6-aoetyl-gent1sate lo a small wh1to, needle-11ke col1d. It appears to be long, th1n, oolorlose peedles under the mlorosoope. The solld has a sweet, aroant10 odor.

The ocapound 1s .01uble In water, absolute aloohol, 95\% aloohol, dlluto aloohol, other, ohlorororm, acotono, and hot toluone. Howerer, it is lasoluble in othjl acotate and cold toluene.

Tho dry colld 1. stable upon exposure to a1r, but un- tablo In aqueoun nolution, turning brown in sovoral days. The baclo amine is more unatable, tarning brown within I hour. The oompound gives positive tosts for nitrogen and ohlorine.

The forr1o obloride to st is positive.

Analjales Caloulated for $\mathrm{C}_{16} \mathrm{H}_{24} \mathrm{O}_{5} \mathrm{NCl}$ N, 4.05; $\mathrm{Cl}$, 10.25. Found: H, 3.96, 4.11; C1, 10.44, 10.25.

loutral equivalent. Caloulated for $\mathrm{C}_{16} \mathrm{H}_{23} \mathrm{O}_{5}$ N: 309.35 . Found 310.36, 308.56. 


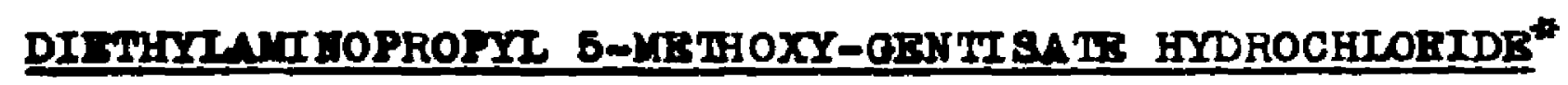

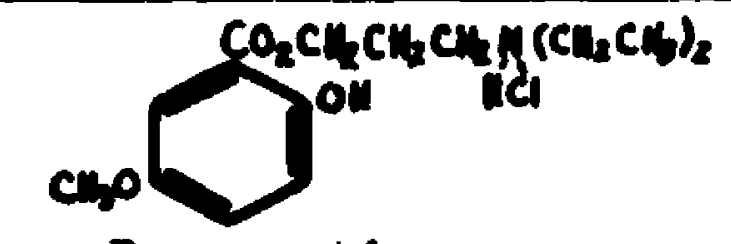

\section{A. Proparation}

D10 thjlaminopropyl b-we thaxy-gent1 sate hydroohlor Ide wae prepared by the Interaction of diethylaminopropyl ohloride and s-mothoxy-gont1a10 ao1d (42).

Iquimolar portions of the ingredients wore mixed in 1sopropanol and refluxed 6 hours. Upon coollng 54.7\% of a wh1te, floooulant $021 d$, m.p. 185.0-186.5 (Corr. 189.5192\%), preolpitated.

The produot was reoryotallized from 1sopropanol twloe to J101d 48.16 of wh1te, flooculant sol1d, m.p. 184.5-185.3 ${ }^{\circ}$ (Corx. 189-189.8 ${ }^{\circ}$ ).

The oompound was dried in tho Abdorhaldon Piotol as provlousls dosoribed. No ohange in molting point was not1oed. 


\section{b. Propertios}

D1 ithylavinopropyl 5-gethoxj-gent1se to hydrochlor 1 de 1. anito, rloooulant powder. It appears to be ahort, thin, oolorlese neodles under the miorosoope. It has a sweot, aromat10 aroma.

The ocmpound 18 voluble in water, 95\% aloohol, absolute aloohol, d1lute aloohol, ohloroform and hot 1sopropanol. It 1. Ineoluble in oold isopropanol.

Tho salt 10 tablo as a solid, but unstablo in aqueous solution, in whion 1 t turn brown. The color change is faoll1tated by alkal1.

Quall tative olomental analys se sows nitrogen and ahlorine.

The forrio ohloride oolor tost 1o positive.

Analyelez Caloulated for $\mathrm{C}_{15} \mathrm{H}_{24} \mathrm{O}_{4} \mathrm{NCl}$ N, 4.41; Cl, 11.16. Found: N, 4.38, 4.32, Cl, 11.25, 11.29.

Ioutral equiralent: Caloulated for $\mathrm{C}_{15} \mathrm{H}_{23} \mathrm{O}_{4} \mathrm{~N} 2 \quad 281.34$. Pound: 875.81, 284.53. 
DIETHYIAMINOPROPYL 5-BENZOYL-OKNTISATE HYDROCHLORIDE*

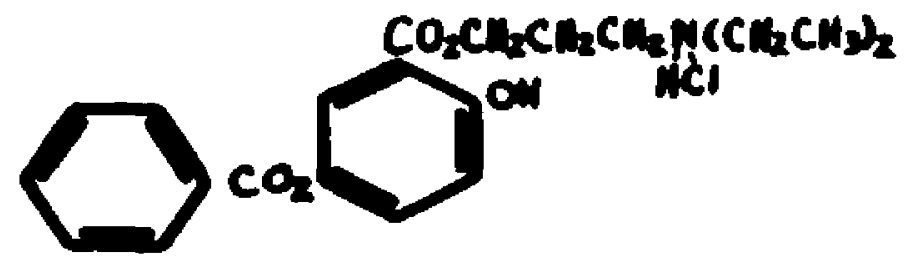

\section{Proparation}

D10thylaminopropjl 5-boneogl-gentisa to hydrochlorido was propared by the Horonstein and Pahllohe roaction (42). D10thylaminopropyl ohloride was addod to solution of 5-bonsojl-gentisio aold in 1sopropanol. Tho mixturo was rorluxed for 4 hours, was oooled and tho solvent was oraporated. The mane j10lded $31.6 \%$ of a whito solld, m.p.

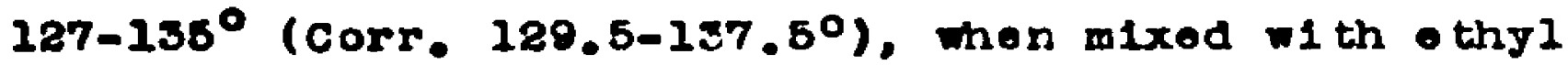
aotate.

Opon 2 reoryatallizations from toluene, the yleld was

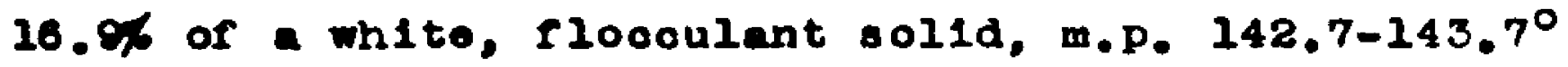
(Corr. 145.2-146, $2^{\circ}$ ).

Tho oter was driod in tho Abdorhaldon Drying P1stol as proviounis desoribed, and no ohange in molting point was not1oed. 


\section{b. Propertios}

D10 thylaminopropjl 5-bonsoyl-gentlsate hydroohloride

10 a wite, Iluffy solld whloh appears to bo smell, oolor10es needles when viered with the mlorosoope.

Tho produot is coluble in wator, absolute aloohol,

95\% aloohol, ohlor of orm, hot toluene and acotone. It 18 Inooluble in oold toluone, other and othyl aootato.

The ester 1s otable when exposed to alr, but turns brown In aquoous olution after covoral days. basic solution hastons the oolor ohange.

qualitativo oloment analyols shows nitrogen and ohlorine to be present.

The forr 10 ohloride tost is positivo.

Analja1.. Caloulatod for $\mathrm{C}_{21} \mathrm{H}_{26} \mathrm{O}_{5} \mathrm{NCl}^{2} \mathrm{~N}, 3.43: \mathrm{Cl}, 8.69$; Founds $1,3.58,3.61 ; \mathrm{Cl}, 8.60,8.64$.

Noutral equirelent. Calculatod for $\mathrm{C}_{21} \mathrm{H}_{25} \mathrm{O}_{5} \mathrm{~N}: 373.42$ Foundz 365.12, 367.56. 


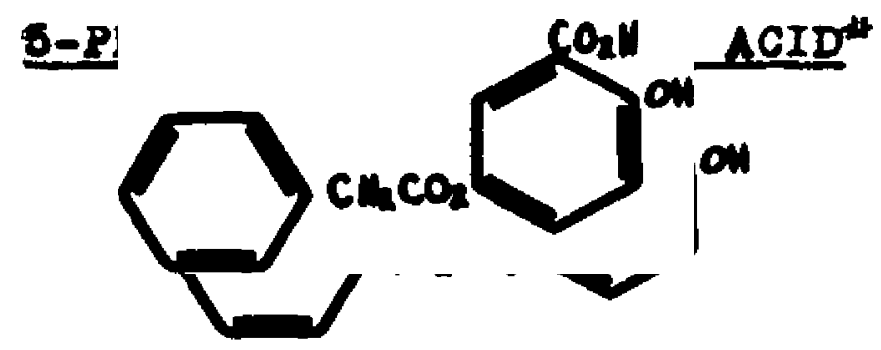

\section{A. Proparation}

B-phenjlaoetyl-gent1a10 ao1d was propared by the intereotion of phenjlaoetyl ohloride and gont1sio nold. The Sohotten-Beman tjpe reaction was used (59). The reaction was oultable booause of the high reactivity of the number 5 phonolio funotion of gentisio aold in alkalino modia and the Inertmes of the number 2 phenollo funotion.

Phenjlaoetyl ohloride was produced in the usual manner, 1.0. Interaotion of phenglaoet1o cold and thlongl ohloride. Upon rewoval of the excess thiongl ohlorlde, the remainder was dietilled to fleld 78.0\% of red oolored, atrongly 1rr1tant wolling, 011g 11qu1d, b.p. $138^{\circ}$ at $30 \mathrm{~mm}$.

Gontiolo a.1d, $6 \mathrm{~g} .(0.04$ molo), was disaolved in $30 \mathrm{ml}$. or 10,6 cediun hjaroxide and $5.4 \mathrm{~g} .(0.04$ mole) or phonylcotyl ohlorido was added with rapid ot1rring. A groat anount of heat was evolved and when the mixture was cooled onls a olight anount of proolpitation took plaoe. The mixture, however, jlelded $7 \mathrm{~B} .(65.9 \%)$ of dense, light jellow

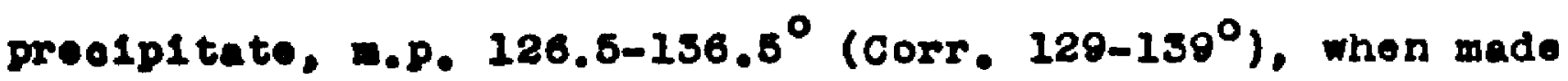
ao1d10 with dilute hraroohlorio no1d. 
The reaotione that took place in the above proparation woro at followes

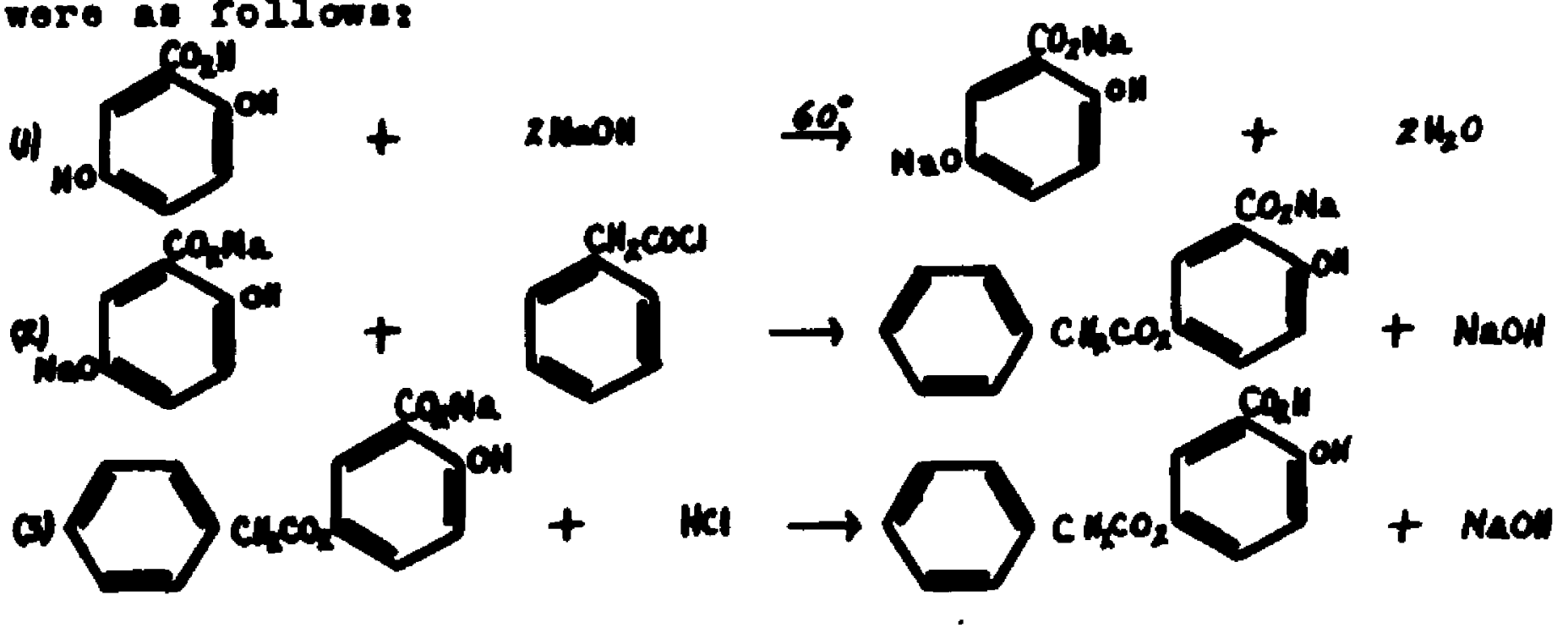

The produot wes mixture of white, rluffy solid and ro120w, ourdy sol1d, w.p. $141.5-144.5^{\circ}$ (Corr. 144-147\%), wen repreolpitated from an eotone solution bJ adding water.

The mixture $a^{101 d e d} 3$ g. $(28.3 \%)$ of a whito, fluffy

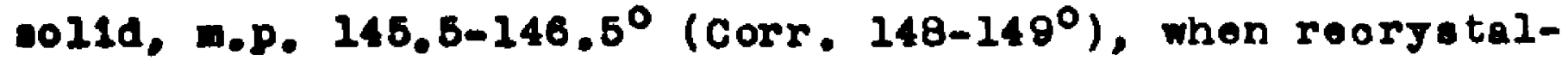
11 sed fros water.

The oompound wee dried in the drying plstol in the came manner as the otber oompounds. Ko change in melting polnt of compound rosulted. 
b. Propert1ea

5-phonglacetyl-gontiolo aold 10 ahite, ootton-like sol1d. Under the mlerosoope it appears to be long, thin, oolorlese flbers. It has no notlooablo odor.

Tho a.dd 1: coluble in absolute aloohol, other, aco tone, 95\% aloohol and ohlorororm. It 18 partially coluble in hot water, but insoluble in oold water.

The product 1s stable on exposure to a1r, but $\mathbf{1 1 1}$ tura brown In water whon solub111zed by basio sodium salta. The phonollo ester gives a atrong blue oolor when ferrlo ohloride is added to an alooholle solution. Analyales caloulated for $\mathrm{C}_{15} \mathrm{H}_{12} \mathrm{O}_{5} \mathrm{C}, 66.27 ; \mathrm{H}, 4.44$. Found 2 C, 66, 21; H. 4,51.

Houtral equivalont. Caloulated for $\mathrm{C}_{15} \mathrm{H}_{12} \mathrm{O}_{5}: 272.25$. Pound: 878.08, 873.78. 


\section{BEPRAITROBITROYL-GIMTISIC ACIP}

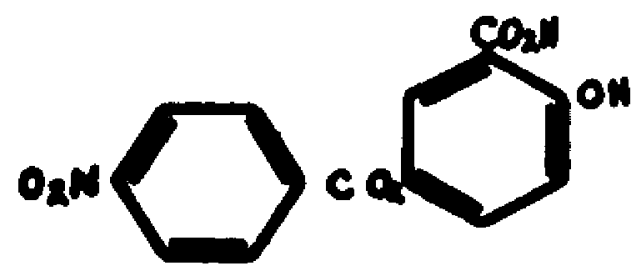

\section{A. Pepretion}

8-paran1trobonsojl-gent1910 ac1d was propared by tho Bahotten-Bauman reation botwon paranitrobensojl ohlorido and gontivio ao1d (50).

Paranltrobensojt chloride wes obtalned in the uaual maner. 1.0. 1nteraotion of the aold and thlongl ohloride (68). The thlongl obloride was eraporated and the realdue roergotalised from teluen to jleld 66.7\% of a jollow,

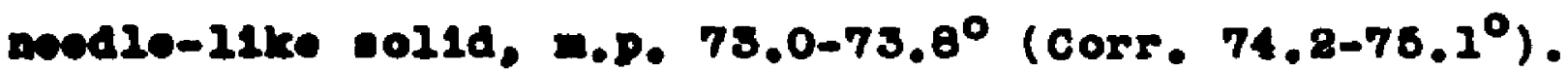

The cold abloride and gent1a10 aold wore reacted ao

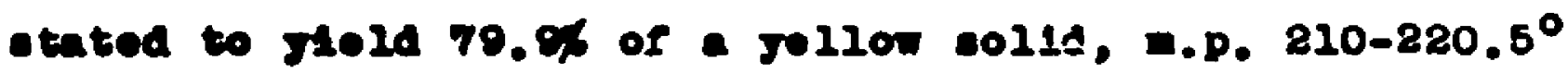
(oors. $\left.815,8.86 .3^{\circ}\right)$.

The orude produet we roorjetalissed from dilute

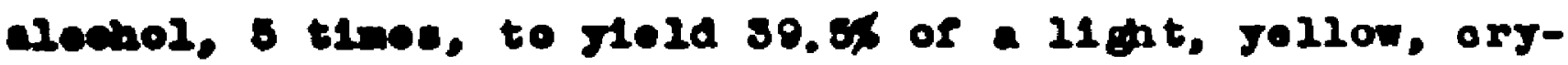

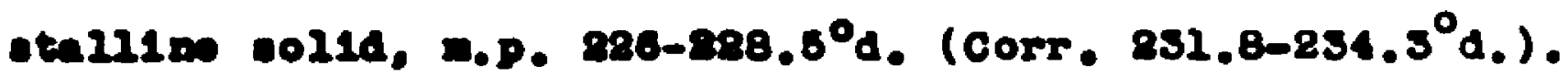
Pinal purifioction by roargatallisation from bolling water

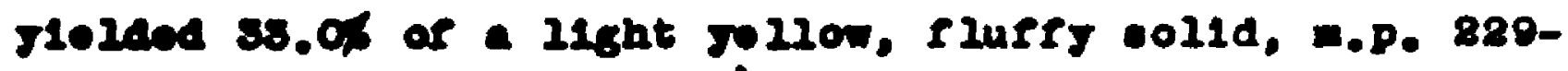
8s0.8\%. (corr. $884.8-886.3^{\circ} \mathrm{d}$ ).

There we no obenge in wolting point range upon drjing the product in the Abderhalden pletol in the nanner dosoribed for the other compounds. 


\section{b. Propert1es}

5-paran1 trobenzogl-gent1a10 ao1d 1a a light yollow, floooulant colld. When viewed under the mlorosoope, it appears to be 11 ght jollow needles.

The produot 10 soluble in 1eobutanol, othyl acotato, hot dilute aloohol, thor and aotono. It is partially soluble in hot water, absolute aloohol and $95 \%$ alcohol, but insoluble in weter, oold dilute aloohol, ohloroform and toluene.

Tho oolid 1a table in air, but in alkaline aquoous colution it rapidly turne brown.

Flement analjala ahows nitrogen.

The aold ahow: a srong forrio ohloride test.

Analje1e: Caloula ted for $\mathrm{C}_{14} \mathrm{Hg} \mathrm{O}_{7} \mathrm{~N}: \mathrm{C}, 55.46 ; \mathrm{H}, 2.99$. Pound: C, $56.43 ; \mathrm{H}, 2.97$.

Houtral equivalent. Caloulated for $\mathrm{C}_{14} \mathrm{H}_{9} \mathrm{O}_{7} \mathrm{~N} ; 303.20$. Founds 305.67, 302.80. 
$s_{0} \cdots$

\section{5-AIBYI-CENTISIC ACID}

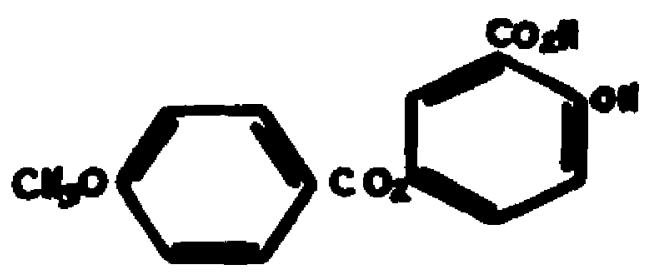

\section{a. Properation}

6-aniej2-gentielo ao1d formed when anisyl chlorido was aded to an alkaline solution of gontisic acid (59). The an1a10 wold wae propared from mothyl-parahydroxybensoate or wothyl paraben. The methylation using methyl aulfate has boen deacribed proviously when the 5-methoxyoarboxyl10 a o1d esere ware disouseod (61).

The jleld was $70 \%$ of a white, noodlo-11ko solid, m.p. $155-175^{\circ}\left(\operatorname{corr} .158 .5-270.0^{\circ}\right)$.

Tho orude produot was rooryatell1zed twloo from water to jlold 50.5\% of a white, noedle-11ke solid, m.p. 184.5$186^{\circ}$ (Corr. 189-190.5\%).

aniagl oblorido was propared by the interection of thionjl onloride and an1610 ao1d. Upon romoval of the thlonjl ohloride, the romalnder was distilled to ylold $74.2 \%$ of a oolorlose, 1rritant smolling, o1ly 11quid, b.p. 128$131^{\circ}$ at $8 \mathrm{mos}$.

When the sohotten-Bauman tjpo roation was ourriod out between aniegl ohloride and gent1.10 a old a j101d of 83.7\%

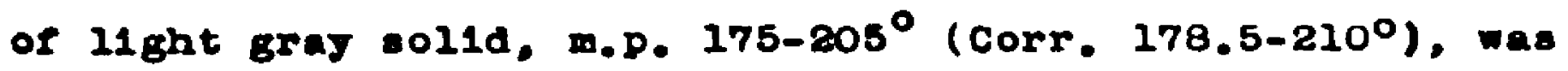
obta1nod. 
The produot war purified by diseolving it alternatoly in hot wootone and hot aloohol, then adding hot water till the colution beome oloudy. After ropeating the purification 3 time a jeld of 66.6\% or a vit te, floooulant sol1a, w.p. $208.4-209.5^{\circ}$ (Corr. 213.9-215.0\%), was obtained. When the eolid was aried in the abderhaiden Drying Piotol as desoribed proviously, no ohange in wolting point took plaoe. 


\section{Propertios}

6-aniogl-gont1sio aold is a light, whito solid. Undor the morosoope it appears as bundles of dense, fine, color10sa noed10e. It 1s odorleas.

The product 1s soluble in absolute aloohol, chloroform, - ther, 95\% aloohol and acetone. It 1a partially soluble In hot water and insolublo in oold water.

The ao1d 1s stable as a solid, but unstable whon plaood in colution by alkaline solubilizer.

The ocmpound gires a positive forric ontoride test. Analye1s: Caloulated for $\mathrm{C}_{15} \mathrm{H}_{12} \mathrm{O}_{6}=$ C, 62.50; $\mathrm{H}, 4.19$ Found: $\mathrm{C}, 62.43 ; \mathrm{H}, 4.54$.

Noutral oquivalont. Caloulated for $\mathrm{C}_{15} \mathrm{H}_{12} \mathrm{O}_{6}: 288.25$ Found: 289.23, 291.76. 


\section{B-ACEYYYISATICYL-CFNTISIC ACID*}

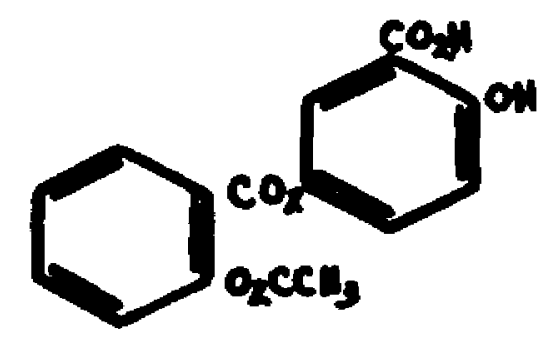

a. Properation

b-aotrleallogl-gont1alo aold was proparod by the Intoraction of aotyleallogl ohlorido and gentisic acid (59).

100tylealloyllo aold was treated with thlongl chlorido and yiolded 62.3\% of a colorloss, strongly irritating 11qu1d, b.p. $135.5-136.5$ at $8 \mathrm{~mm}$. The I1qu1d solldirlod to white powder in soveral days (65).

Gentisio a cold was dissolved in $10 \%$ aqueous sodium hjaroxide and aotgloallogl chloride addod dropwise with oonstant =tirring. Upon cooling, the cloudy solution was made a. with dilute hydroohlorio ac1d. Tho yleld was 73.2x of a 11ght brown sol1d, m.p. 183.5-168.5 (Corr. (67-278).

The orude product was roorgstallized twloo from an aotono-wator mixture and onoe from aloohol-water mixture to y101d 16.26 or a l1ght gray sol1d, m.P. 203.5-204.7 (Corr. $209^{\circ}-210.2^{\circ}$ ).

The m.p. romalnod constent mon tho produot was driod In the Abderhalden P1otol like the othor oompounds.

Hew sor pound. 


\section{b. Propert10e}

5-eoetglealiojl-gentisio ao1d is a wite or light gray, rine. Floooulant powder. Under the mlorosoope amall halrlike beares of oolorlese noedles are seen. The a a 1d soluble in absolute aloohol, 95g alcohol, - thor, 1aobutanol, aootone, and glaolal aootio aoid. However, It is Insolublo in wator, chloroform and dilute acotio a.1d.

The produot is stablo in a1r, but turns derk in aqueous alkaline solution.

A strong positive tost for phenols 18 obtained by uso of ferrio onloride.

Analjales Caloulated for $\mathrm{C}_{16} \mathrm{H}_{12} \mathrm{O}_{7}: \mathrm{C}, 60.76 ; \mathrm{H}, 3.83$. Found: C, 61.74, 61.53; H, 3.92, 3.86.

Noutral equivalent, Calculated for $\mathrm{C}_{16} \mathrm{H}_{12} \mathrm{O}_{7}: 316.26$. Found $289.68,281.11$. 


\section{5, $5^{\prime}-$ SUCCINYI-DI QENTISIC ACIDH}

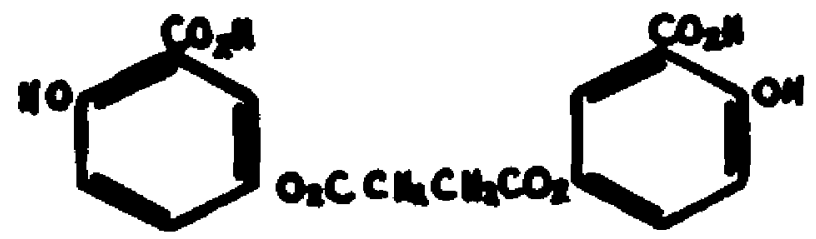

\section{‥ Proparation}

6,5'-auooingl-digentisio aold was preparod, as wero all the phonol10 osters, by the Schotten-Baunan roaction (59).

suoolngl ohlorido was propared by the following prooedure $(66)$.

suooin10 ao1d, 20 B. $(0.17 \mathrm{~mole})$, and $35.4 \mathrm{~g} .(0.17$ wlo) of phosphorous pentachloride were pleoed in a flask provided with an alr condenser in woll ventilated hood. The mixture was heated, in an 011 bath, olowiy to $125^{\circ}$. The mixture firat liquified and then formod a blaok masa. Tho hoating was oontinued 20 hours. Upon cooling, phosphorous oxjohloride was removed and the residue distilled to j1eld $30.0 \%$ of a light jollow-green, 1rritant amelling 11quid, b.p. $84^{\circ}$ at $8 \mathrm{~mm}$.

The following roction repreaents the preparation of aucolngl ohloride.

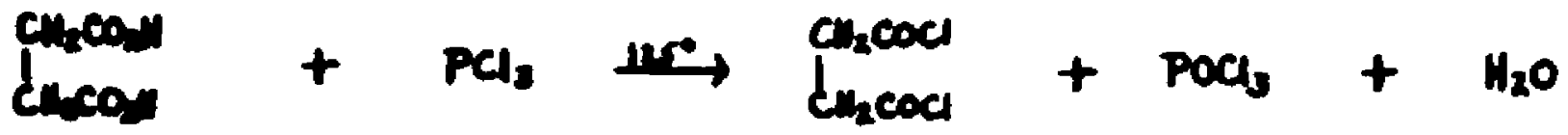

suocingl ohloride and gentisio acid whon reaotod in the ratio of $122, J^{10 l d o d} 27.4 \%$ of a 11ght brown sol1d, m.p. 
220-215 ${ }^{\circ} \mathrm{d}$. (Corr. 215.5-220.5 ${ }^{\circ} \mathrm{d}$ ).

The oruce produot was reorjatallized,3 times,from a aoetone-water m1xture to j101d 12.4\% of a 11ght brown sol1d, m.p. 227-220 d. (Corr. 234-236 d.).

Final røoryatallization from hot alcohol-hot wator j101ded 10.16 or a 11ght brown or wh1te sol1d, m.P. 230$231.5^{\circ} \mathrm{d}$. (Corr. $\left.237-238.5^{\circ} \mathrm{d}_{0}\right)$.

Tho ool1d maintained the same wolting point after drjing in the Abderhalden Drying Pistol as proviously dosor1bod. 


\section{b. Properties}

5,5'-suoolngl-digent1a10 ao1d 1a a vory light brown ar white sol1d. It appoars to be small, oolorlese ribero under miorosoop10 magnifioation.

The product is soluble in aoetone, absolute aloohol, 95\% aloohol and pyridine. It is partially solublo in - ther, but insoluble in chloroform, water, bonzene and toluene.

The a.1d 1. atable on exposure to air, but unstablo in aqueoue alkal1, turning brown in short time.

Tho ferric ohloride tost 1 o positive.

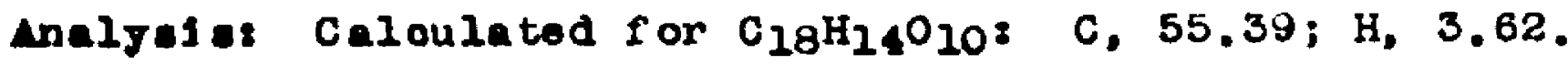
Pound: C, 56.20; H, 3.82.

Houtral equivalont: Caloulated for $\mathrm{C}_{18} \mathrm{H}_{14} \mathrm{O}_{10}: 390.29$ Found: $387.69,389.14$. 
Proar of Strueture of the Srnthealzed Eaters br the Analrabe of Tho ir Infrared Spoctre.

In anj obomioal aynthoala it 10 noovesary to prove the atruoture of the oompound prepared. Quantitative analyais of the eloment oontent of a oompound and the dotormination of othor phyelonl constants, 1.0. molooular wolght, of the product outabliahes onls 1 ta omplrioel formula. The posalb111ty at1jlexists that the compound may be an 1aomer of the desired eynthotio. By use of Infrared analysis the funotional groupe of the compound can be determined. The "ringer printe of tho oompound 1s anid to have been obtainod. The Infrared peotra of the oompounds prepared have been ut111sed In this war to determine the ir struoture.

An atom nay absorb energy in the form of heat or $11 \mathrm{ght}$ by copverting the inoldent onergy into a form of potential onares. This 10 aooomplishod by an elootron "jumping" from a 10r-onergJ level to a highor onergy level. This makea up the absorption epeotrum of an atomio vapor wioh generally conelete of a fow dark l1nos.

Howerer, there are three waye In whioh disorete amounts of eneres may be abeorbed by moleoular vapor. The firat is the lootron jump. In moleoule the posalble oleotronio opergy lovela aro modirled by the presenoe of soveral atoma, therefore energJ maj bo absorbed bj oonverting it into onergy or vibration or rotation. In goneral, the onergy in- 
volved in the ohange of energs lovele or an elootron is greater than that involved in vibretion or rotation. Therefore, In a moleoule, the absorption line corresponding to a Ingle eloetronio enorgy ahange is found to be spread out into a band of manj fine 11 nos booause of the many pos1ble value of vibrational and rotational energy ohanges. Thle oondition holds true in genoral for a molecular rapor or gas. If this gas 1s comprosad, howover, it is observed that the fine I1nea of the band speotrum coalosoe because of the efreots of orowding the moleoules together. PInalis, in a 11quid, all the Iine atruoture w11l boodo - imply a region of absorption. Suoh an absorption region ary represent only a angle eleotron transition, modifled bj vibrational and rotational offoota.

Infrared and Raman sootra usually 1nvolve onorgy trans1tione due to vibration and rotation alono. It is thus poseible to etudy the dynamios of the moleoule 1tself. (67).

The Infrared peotropbotomotor la uaed for quantitative nenauremente of conoentration and oven for au tomatio control and reoording. In addition, it is valuablo tool for do tooting and ldentifjing wall amounts of lopuritios and for the eluoldation of the etmuoture of molooulos. (68). The etabliahment of molooular atruoture has an omplr laal basis and reots on tho observation that oortain ocubinations of atcons. Irequently in oomplex moleoules, maj be aceoolated with oertain absorption bands in tho 
Infrated of these eubetanoes. If the bande produced by -aoh a tonio croup woro lnvariant and unique in tho1r posit1on in the epootra of all substanoes oontaining the group 1t would be lmediately poselble to determine the presence or absenes of anj group in a given molooule by the measuremont of 1te Infrared spotrum. However, oach oompound possesses 1ts own spootrum. The other stuotures adjacont to a given group inf luenoe 1t. olootronic and epatiel conf1guratione. In addition, the masses of the other atoms are Involved in the vibretion ohange srom molecule to moleoule. Ae a result, a given group may show somowhat difforent values for 1 ts absorption band In the spoctra of difforent moleoules whioh oontaln 1t. Further, tho bands due to one group in one compound may have tho samo wave length value es en entirely different atruotural group in anothor oompound. As a roeult, somo dogree of unoertainty may attach 1taelf to the Interpretation of bands suepeoted of omonating from anj partioular group.

4 oomplete tost of a given molocular structure based on Infrared date would result only if a proolso mathomation computation would prediot from the etruoture the speotrum sotually observed. Suah proor is possible only in eimple moleoules. It has boen sohleved for a number of suob molooules were tho Intramoleoular linkages were woll known and only the orlentation of the bonds and the interatomio distances were unkenown. 
The above oonditione were never fulfillod for complex moloculea. The abeorption apootrum and IImlted ohomical date are the onls cources of Information ava1lable. The Intramolooular alatanoes are unknown, and tho ro is ittio or no basis for oomputation. Bven when the linkages are known, the complexity of the moleoules defles auch an appronoh. Under these oonditions it 1s neoeveary to reart to ompiriolem and to draw onclusions about atrisotures by corrolationa between bands whlah ooour regularly with reourring atruotural featurea throughout a seriea of compounde.

The Interpretation of the spootrum, besed upon oomparison with the pootrum of oompounds containing aimilar known funotional groupa, In combination with other physioal and ohomionl oridenoe may furnioh a guldo oufficiont for the Identifioation of the atructure of the oompound. (69). 


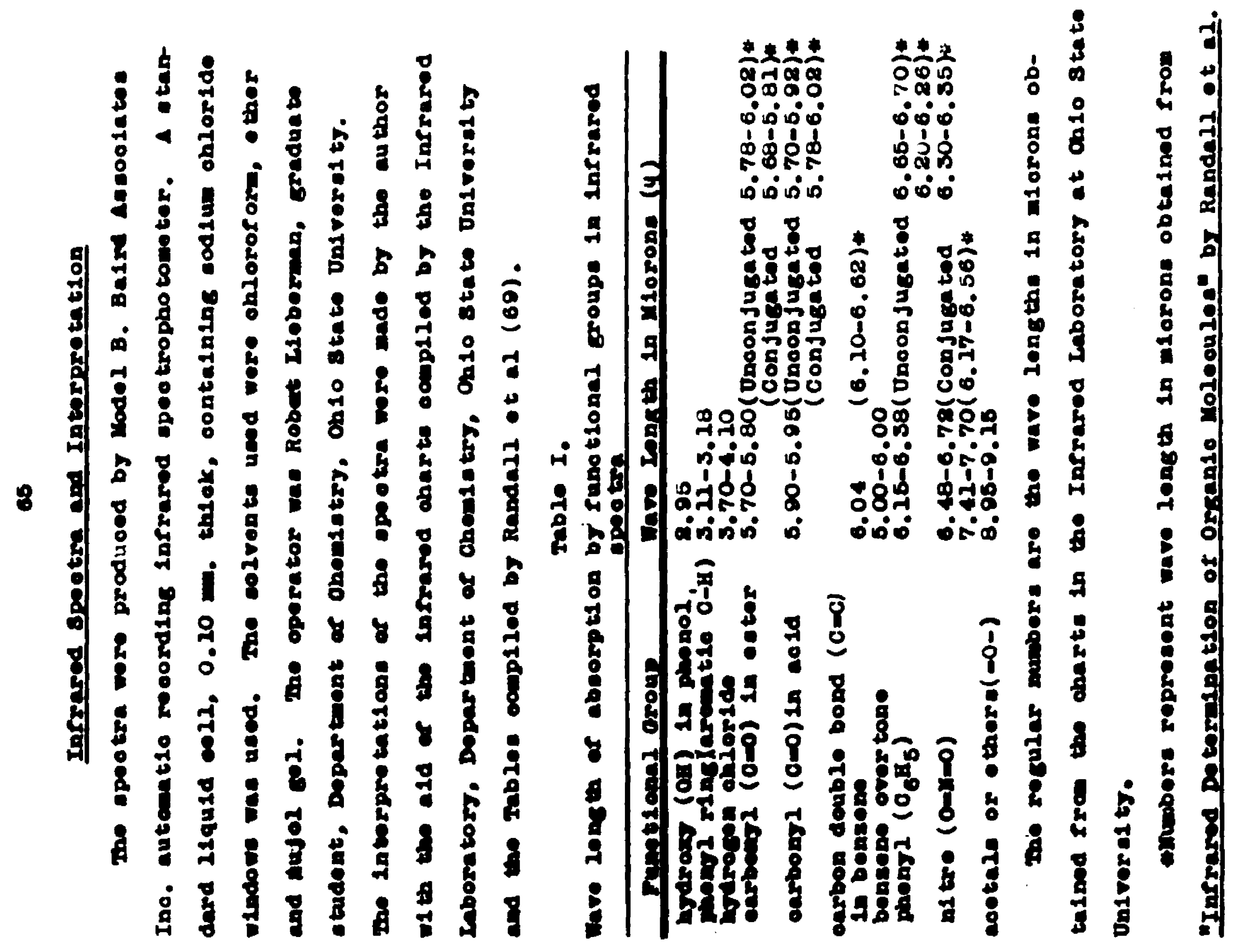




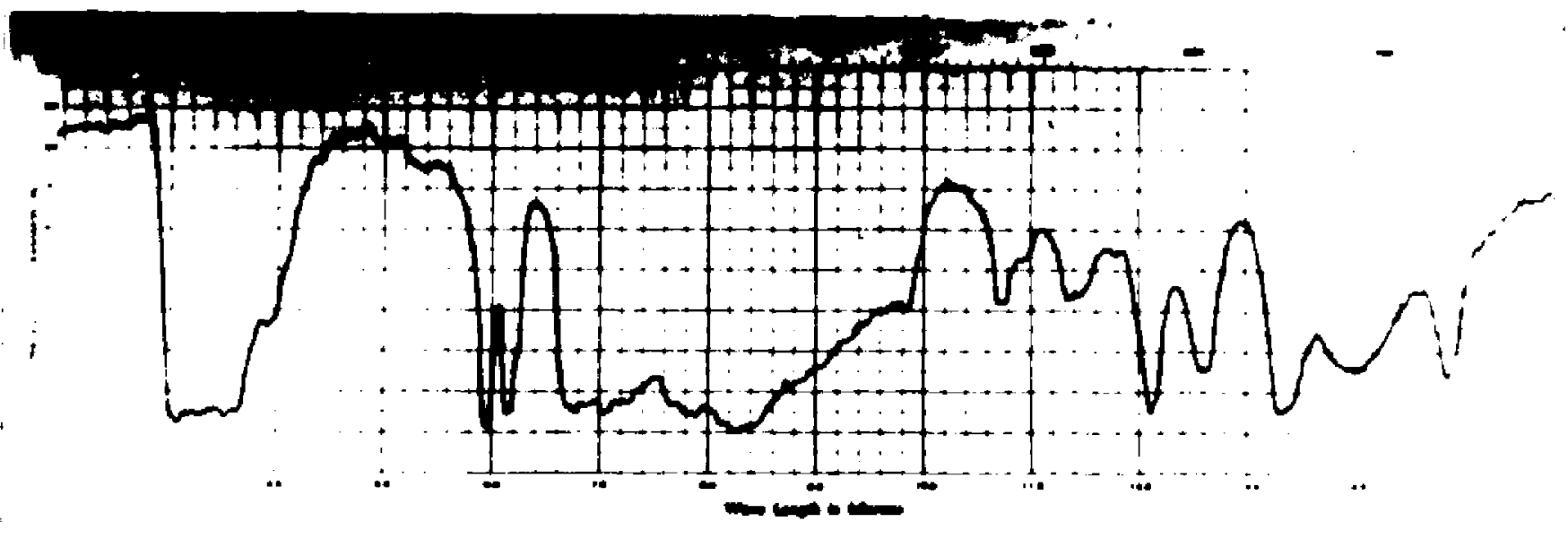

Flgure 1

Infrared Spectrum of Gent1sio Aold

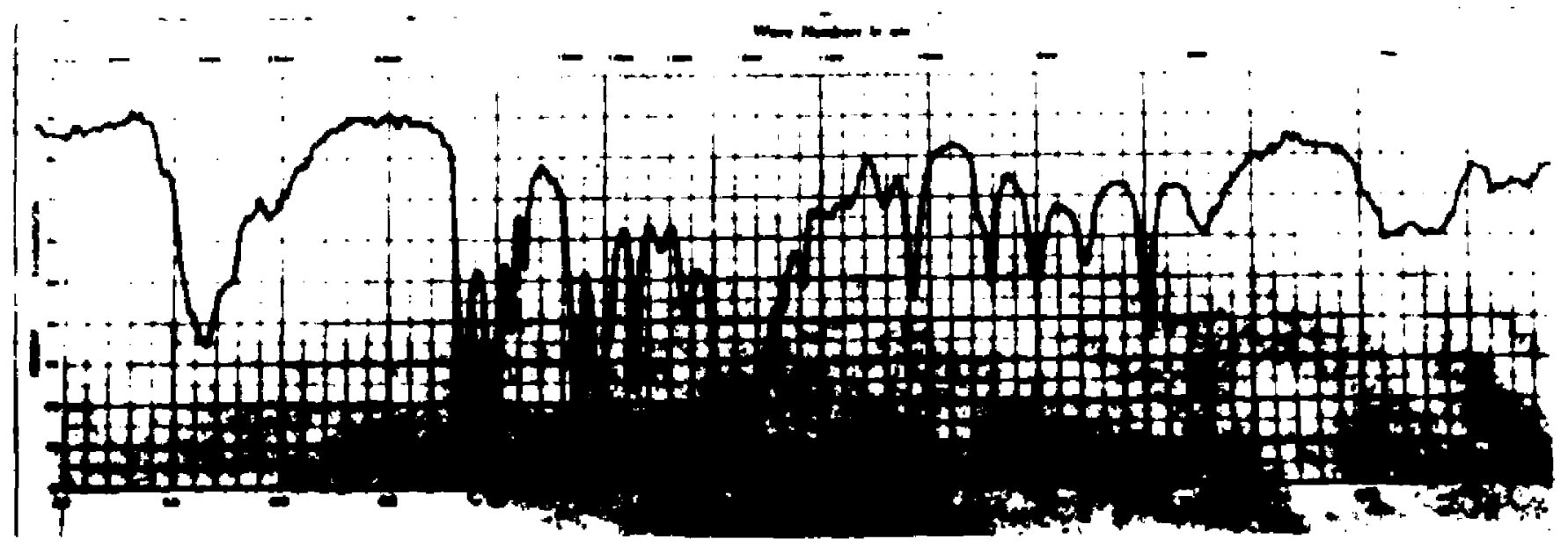

Flgure 2

Infrared Speotrum of 5-Aootyl-Gontisic Ac1d

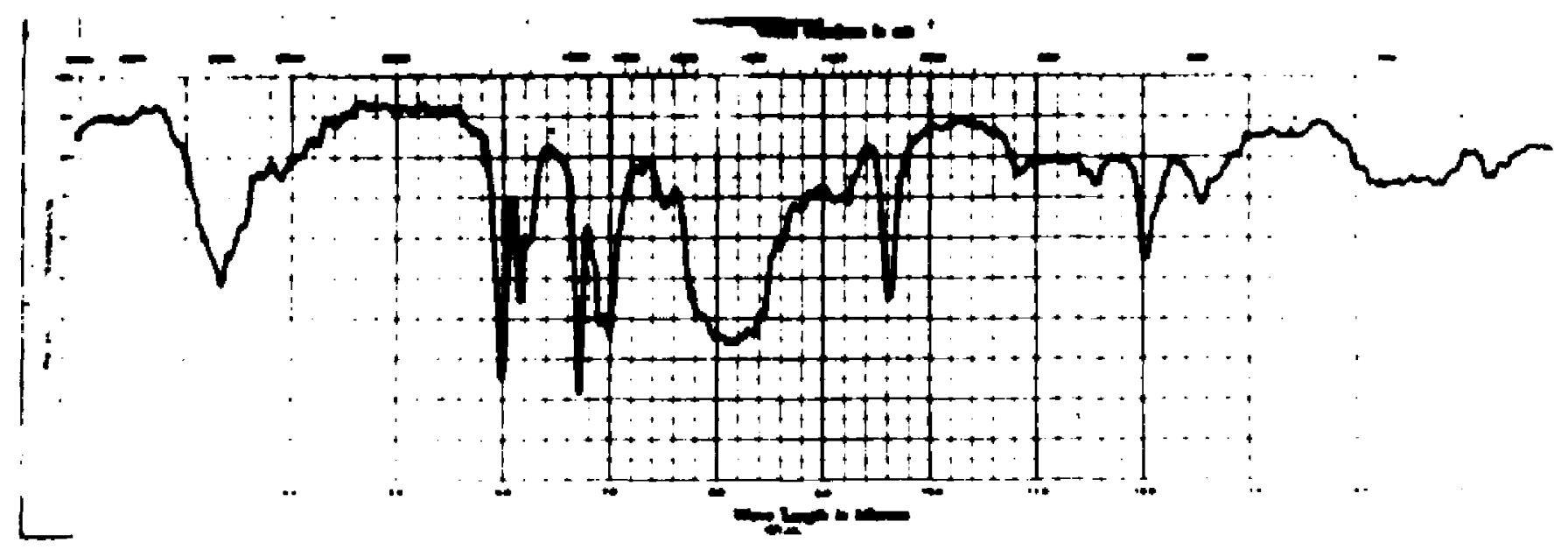

F1gure 3

Infrared spootrum of 5-Mothoxy-Gentialc Aold 


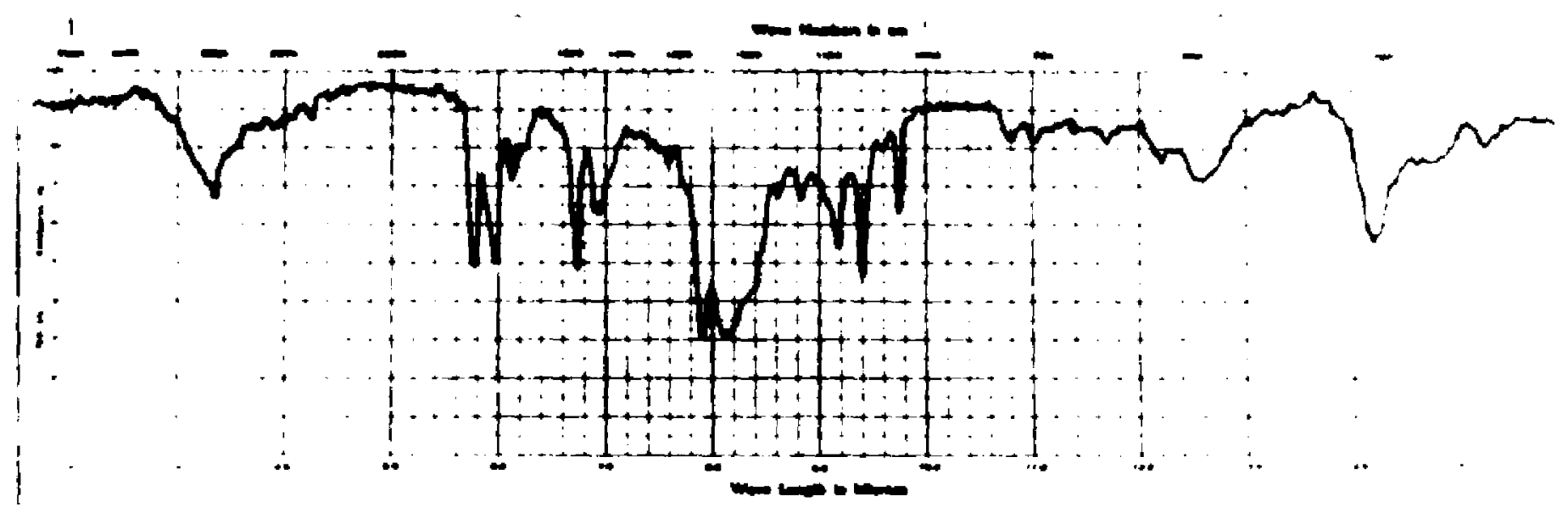

Figure 4

Infrared Speotrum or 5-Benzoyl-Gentisic Ac1d

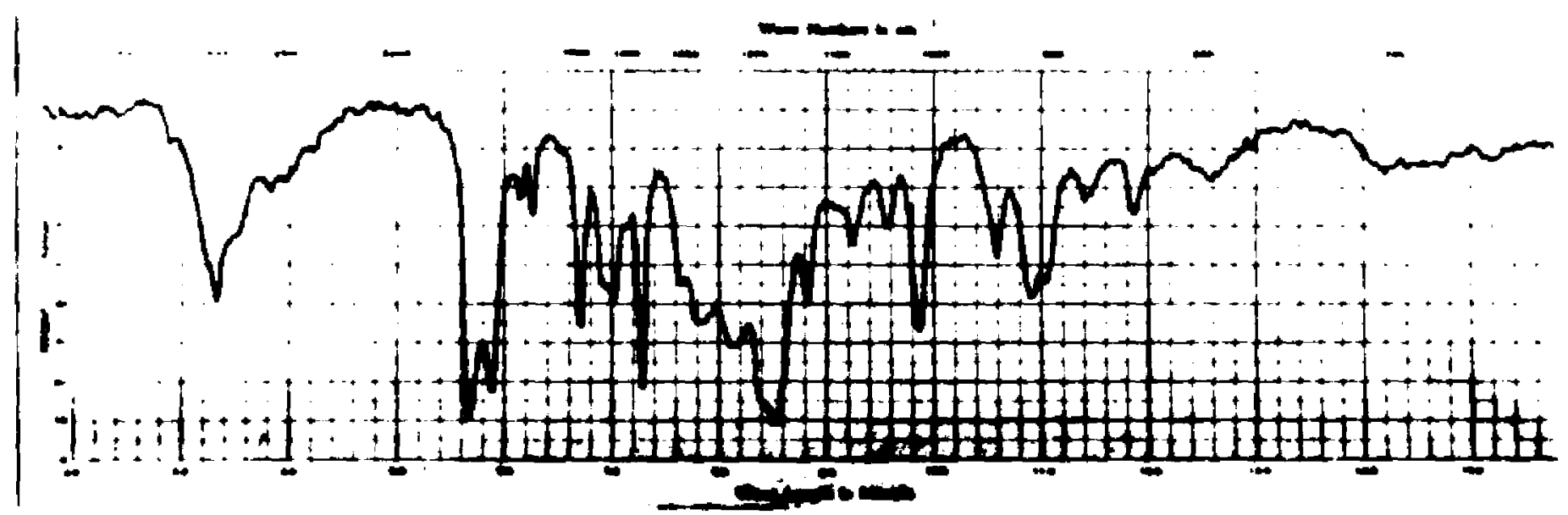

F1gure 5

Infrared Speotrum of Diaootyl-Gent1s10 Acld

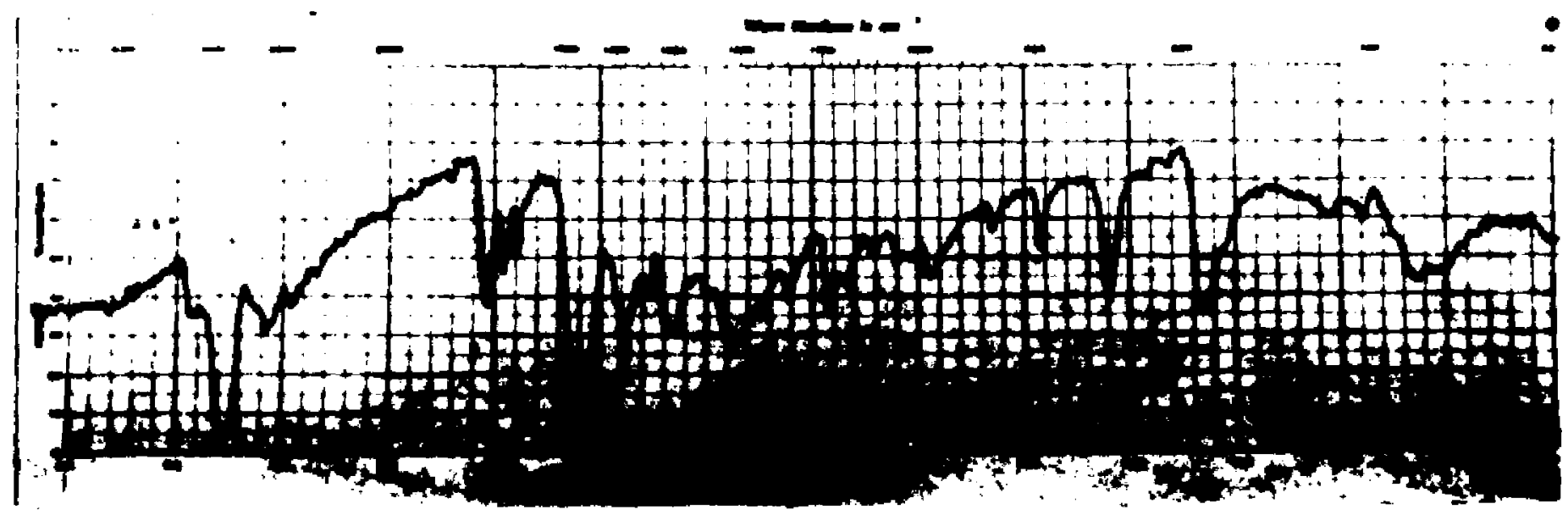

E1gure 6

Infrared speotrum of Diethyleminoe thyl-Gentisate Hydroohlor1de 
Tab le II.

Analyaes of Infrared Spootre of Known Compounds

\begin{tabular}{|c|c|c|c|c|c|}
\hline $\begin{array}{l}\text { P1gure } \\
\text { Number }\end{array}$ & $\begin{array}{l}\text { Known } \\
\text { Compound }\end{array}$ & Solvont & $\begin{array}{c}\% \\
\text { Conoen- } \\
\text { tration }\end{array}$ & $\begin{array}{c}\text { Functional } \\
\text { Groupa }\end{array}$ & $\begin{array}{l}\text { dilaximum of } \\
\text { Absorption } \\
\text { by Function- } \\
\text { al Groups } \\
\text { in } 4\end{array}$ \\
\hline 1 & $\begin{array}{c}\text { Gontiolo } \\
101 d\end{array}$ & $\mathrm{CH}_{3} \mathrm{OCH}_{3}$ & 10 & $\begin{array}{l}\text { UH in phonol } \\
\text { Ar comatio C-H } \\
C=0 \text { in acid } \\
C=C \text { in benzene } \\
C_{6} \mathrm{H}_{6}\end{array}$ & $\begin{array}{l}2.89 \\
3.09 \\
5.95 \\
6.14 \\
6.75\end{array}$ \\
\hline 8 & $\begin{array}{l}\text { 5-Aootjl- } \\
\text { oontialo } \\
\text { Aold }\end{array}$ & $\mathrm{CHCl}_{3}$ & 5 & $\begin{array}{l}\text { Aromatic } \mathrm{C}-\mathrm{H} \\
\mathrm{C}=0 \text { in ester } \\
\mathrm{C}=0 \text { in acid } \\
\mathrm{C}=\mathrm{C} \text { in benzene } \\
\mathrm{C}_{6} \mathrm{H}_{5}\end{array}$ & $\begin{array}{l}3.30 \\
5.69 \\
5.97 \\
6.12 \\
6.72\end{array}$ \\
\hline 3 & $\begin{array}{l}\text { 6-Mothoxy- } \\
\text { gont1e10 } \\
\text { Lold }\end{array}$ & $\mathrm{CHCl}_{3}$ & 2.5 & $\begin{array}{l}\text { Arometio } \mathrm{C}-\mathrm{H} \\
\mathrm{C}=0 \text { in acid } \\
\mathrm{C}=\mathrm{C} \text { in benzeno } \\
\mathrm{C}_{6} \mathrm{H}_{5}\end{array}$ & $\begin{array}{l}3.34 \\
5.98 \\
6.15 \\
6.71\end{array}$ \\
\hline 4 & $\begin{array}{l}\text { 6-Bonzoyl- } \\
\text { Gent1sio } \\
\text { lo1d }\end{array}$ & $\mathrm{CHCl}_{3}$ & 5 & 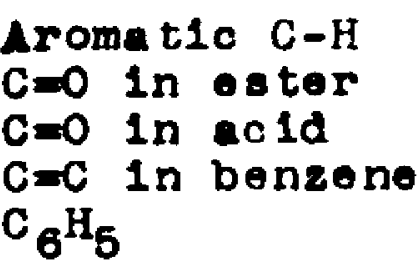 & $\begin{array}{l}3.35 \\
5.76 \\
5.98 \\
6.12 \\
6.73\end{array}$ \\
\hline 5 & $\begin{array}{l}\text { Dinoetjl- } \\
\text { Gentiolo } \\
\text { Aold }\end{array}$ & $\mathrm{CHCl}_{3}$ & 5 & $\begin{array}{l}\text { Aromatio } \mathrm{C}-\mathrm{H} \\
\mathrm{C}=0 \text { in oter } \\
\mathrm{C}=0 \text { in aold } \\
\mathrm{C}=\mathrm{C} \text { in benzene } \\
\mathrm{C}_{6} \mathrm{H}_{5}\end{array}$ & $\begin{array}{l}3.32 \\
5.67 \\
5.87 \\
6.15 \\
6.72\end{array}$ \\
\hline
\end{tabular}




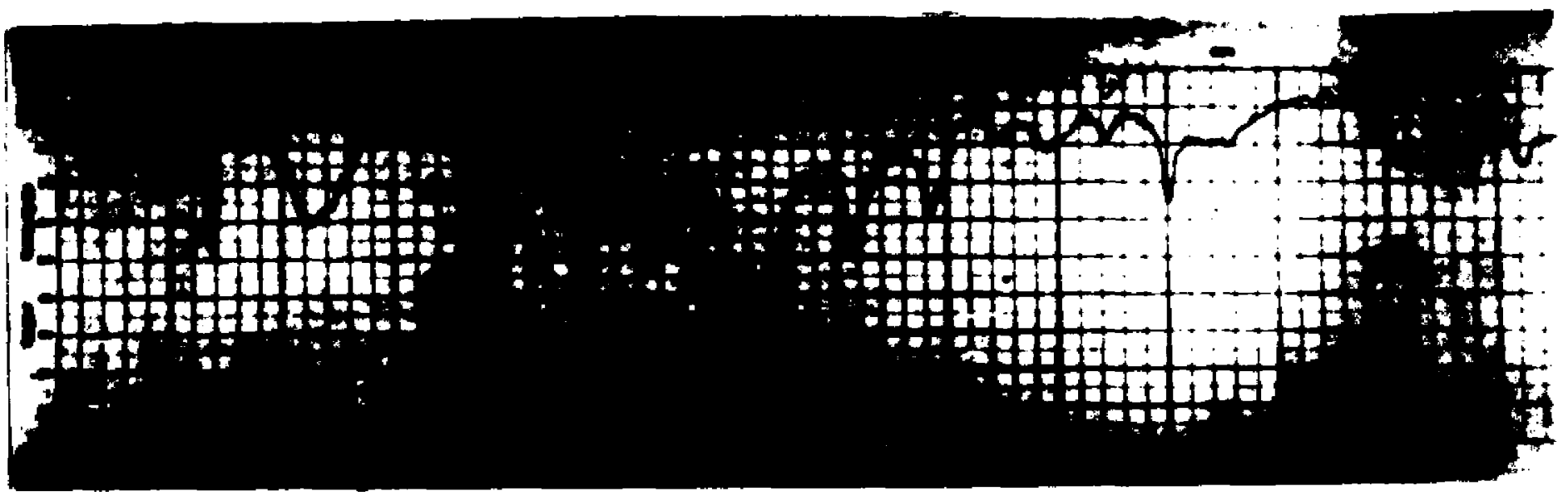

P1gure 7

Infrared Speotrum of Diethylaminoothyl 5-Aoetyl-Gentisato Hjaroohlor 1de

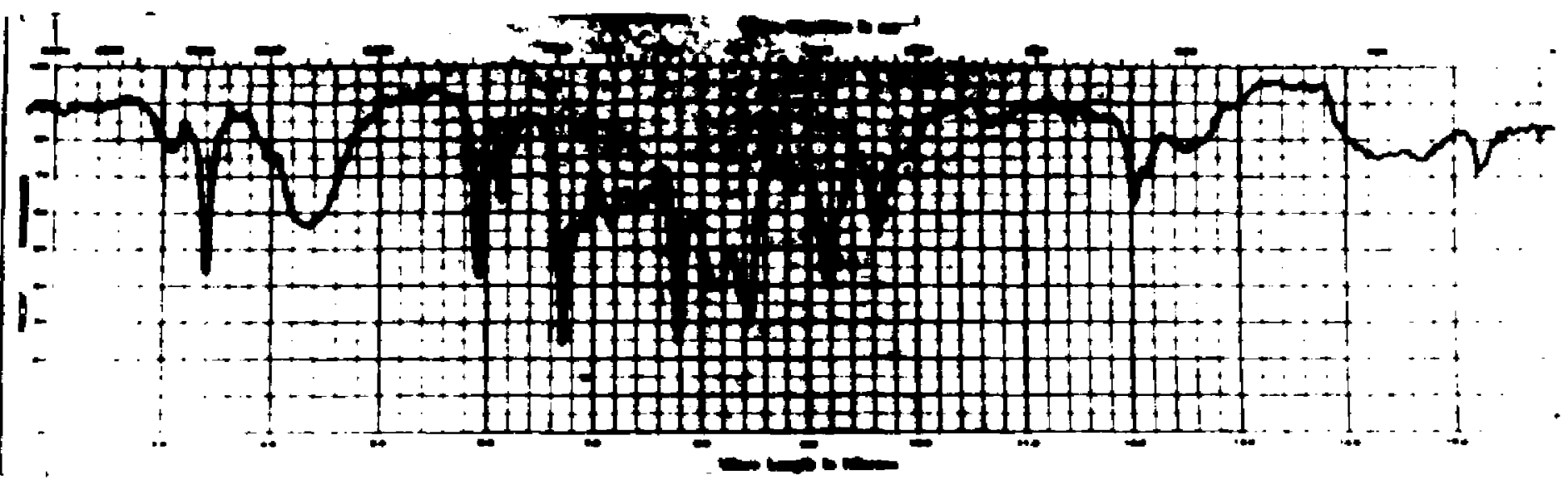

Figure 8

Infrared Speotrum of D10thyiaminoethyl 5-Hethoxy-Gentiante Hydroohlor 1de

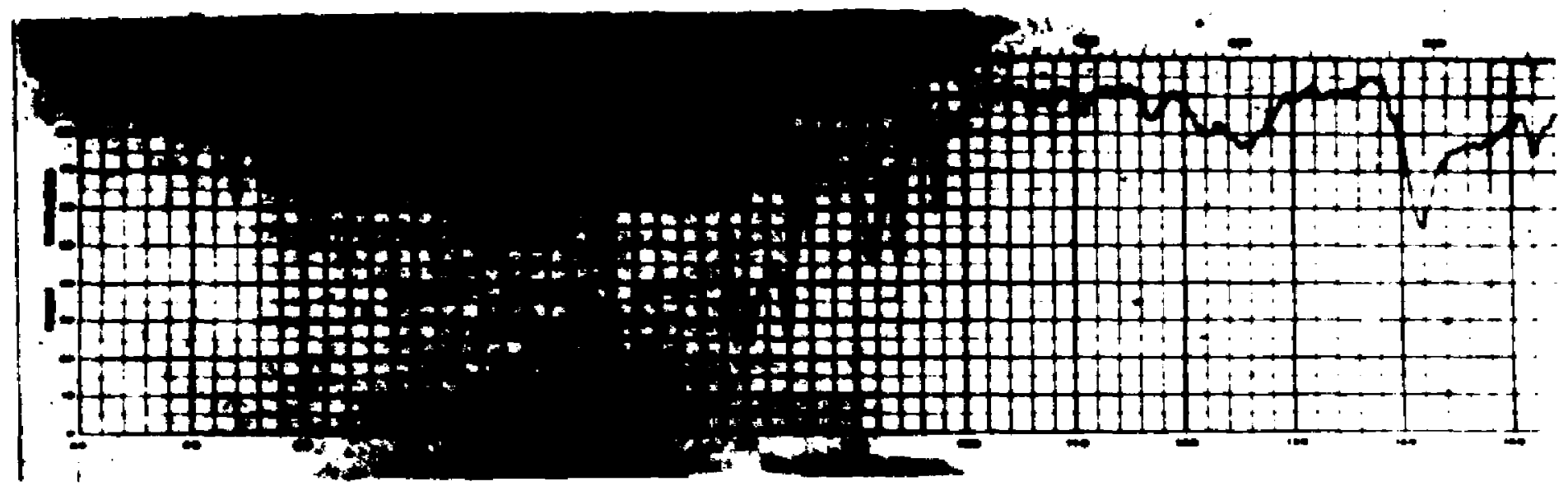

F1gure $\theta$

Infrared Speotrum of Diethylaminoothyl 5-Benzoyl-Gent1 cato Hydroohlor 1de 


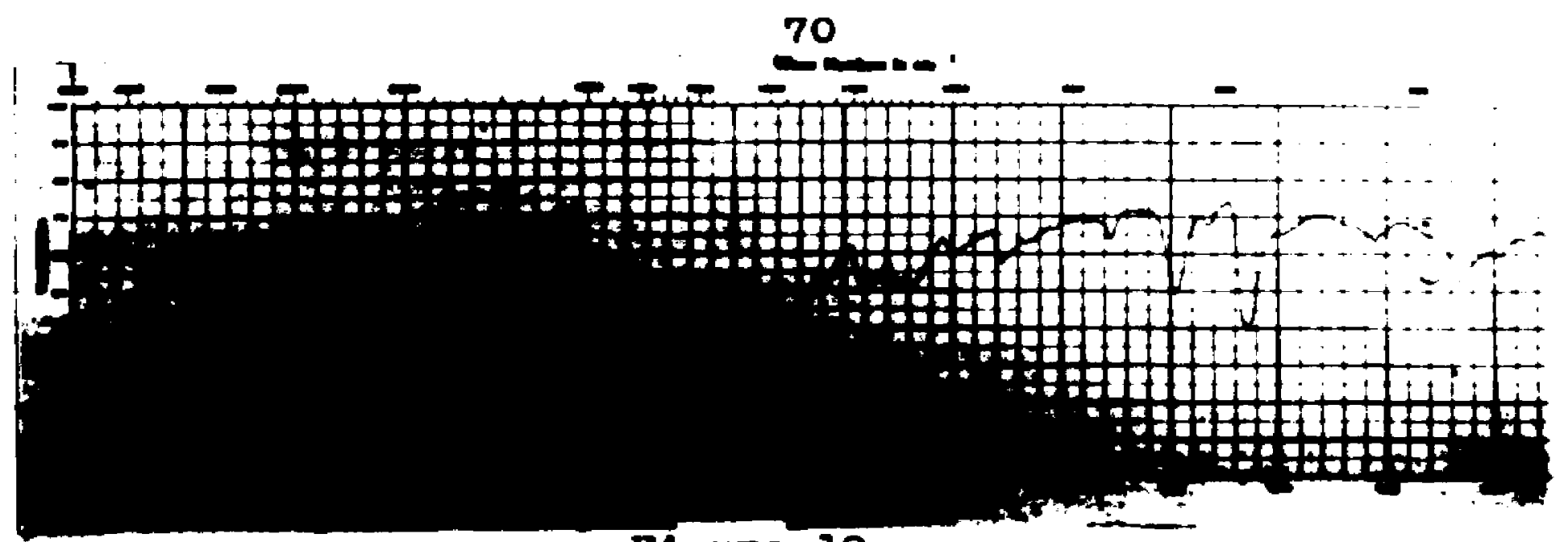

Pigure 10

Infrared spootrue of Diethylaminopropjl Gentiaate Hydroohlor 1de

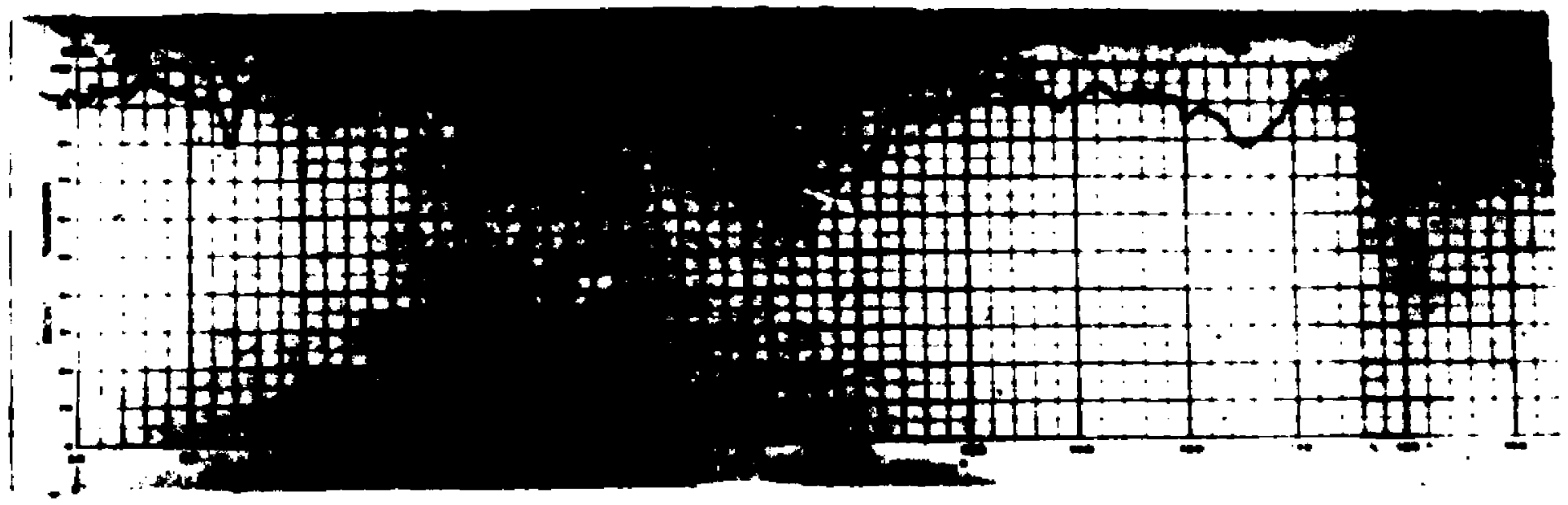

F1gure 12

Infrared speotrum of D1ethyleminopropyl 5-Acetyl-Gentisate Hydroohlor 1de

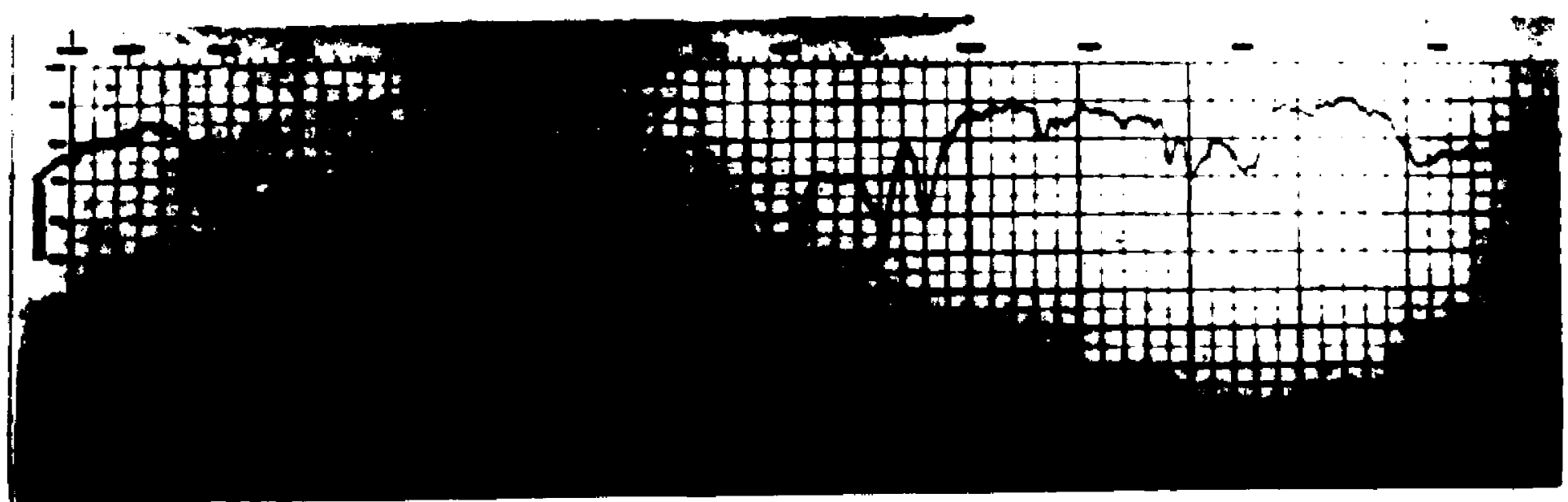

Plgure 18

Infrared speotrum of Diethjlaminopropjl 5-Mothoxy-dentisate Hjdroohlor 1de 
Table III.

Analyaea of Infrared Speotra of Diothyleminoe thenol Esters of gontialo Ao1d

\begin{tabular}{|c|c|c|c|c|c|}
\hline $\begin{array}{l}\text { F1gure } \\
\text { Number }\end{array}$ & $\begin{array}{l}\text { Synthe t10 } \\
\text { Compound }\end{array}$ & Solvent & $\begin{array}{l}\text { \% Con- } \\
\text { oentra- } \\
\text { tion }\end{array}$ & $\begin{array}{c}\text { Funotional } \\
\text { Groupa }\end{array}$ & $\begin{array}{l}\text { diarimum of } \\
\text { aboorption } \\
\text { by funotion- } \\
\text { al group } \\
\text { in } 4\end{array}$ \\
\hline 6 & $\begin{array}{l}\text { Orowhyl- } \\
\text { aminoe thyl } \\
\text { gentioate } \\
\text { Hydroohloride }\end{array}$ & Nujol & -- & $\begin{array}{l}\text { of in phenol } \\
\text { Aromat } 1 \mathrm{C} \text { C-H } \\
\mathrm{C}=0 \text { in ester } \\
\mathrm{C}=\mathrm{C} \text { in benzene } \\
\mathrm{C}_{6} \mathrm{H}_{5}\end{array}$ & $\begin{array}{l}3.12 \\
3.42 \\
5.92 \\
6.08 \\
6.72\end{array}$ \\
\hline 7 & $\begin{array}{l}\text { Die thyl- } \\
\text { aminoe thyl } \\
5-A 0 \text { tJl- } \\
\text { gent1eate } \\
\text { Hydroohloride }\end{array}$ & $\mathrm{CHCl}_{3}$ & 10 & $\begin{array}{l}\text { OH in phenol } \\
\text { Arometic C-H } \\
\text { ECI } \\
C=0 \text { in ester } \\
C=C \text { in benzene } \\
\mathrm{C}_{6} \mathrm{H}_{5}\end{array}$ & $\begin{array}{l}3.10 \\
3.39 \\
4.21 \\
5.66 \\
5.89 \\
6.12 \\
6.73\end{array}$ \\
\hline 8 & $\begin{array}{l}\text { D1e thyl- } \\
\text { aminoe thyl } \\
\text { 5-Mo thoxy- } \\
\text { Gentisate } \\
\text { Hydroohloride }\end{array}$ & $\mathrm{CHCl}_{3}$ & 3 & $\begin{array}{l}\text { OH in ohenol } \\
\text { Aroma } t 1 \mathrm{C} C-\mathrm{H} \\
\mathrm{HCl} \\
\mathrm{C}=0 \text { in ester } \\
\mathrm{C}=\mathrm{C} \text { in benzene } \\
\mathrm{C}_{6} \mathrm{H}_{5}\end{array}$ & $\begin{array}{l}3.08 \\
3.40 \\
4.30 \\
5.93 \\
6.15 \\
6.69\end{array}$ \\
\hline 9 & $\begin{array}{l}\text { Die thjl- } \\
\text { aminoo thyl } \\
\text { s-Bens ojl- } \\
\text { gentieate } \\
\text { Hydroohloride }\end{array}$ & $\mathrm{CHCl}_{3}$ & 10 & $\begin{array}{l}\text { OH in phenol } \\
\text { Arome } \mathrm{C} \text { C } \mathrm{C}-\mathrm{H} \\
\mathrm{HC} 1 \\
\mathrm{C}=0 \text { in oster } \\
\mathrm{C}=\mathrm{C} \text { in benzene } \\
\mathrm{C}_{6} \mathrm{H}_{5}\end{array}$ & $\begin{array}{l}3.08 \\
3.39 \\
4.25 \\
5.76, \\
5.90 \\
6.11 \\
6.70\end{array}$ \\
\hline
\end{tabular}




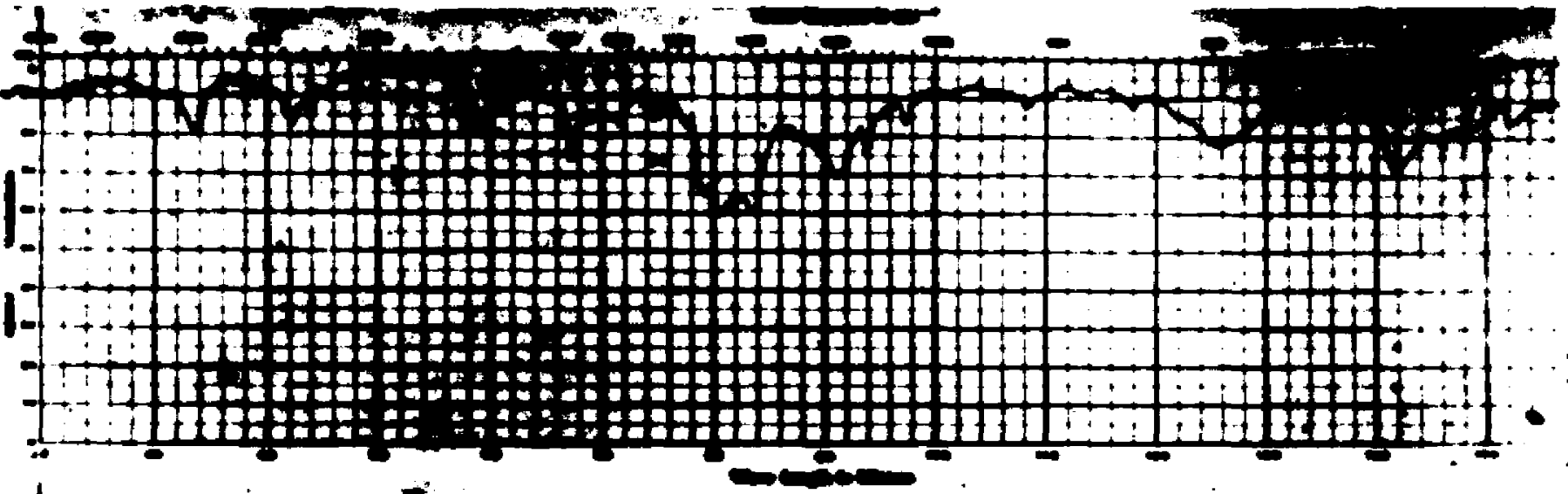

F1gure 13

Infrared Spootrum or Diethylaminopropyl 5-bensoj-Gentiagto Hydroohlor 1do

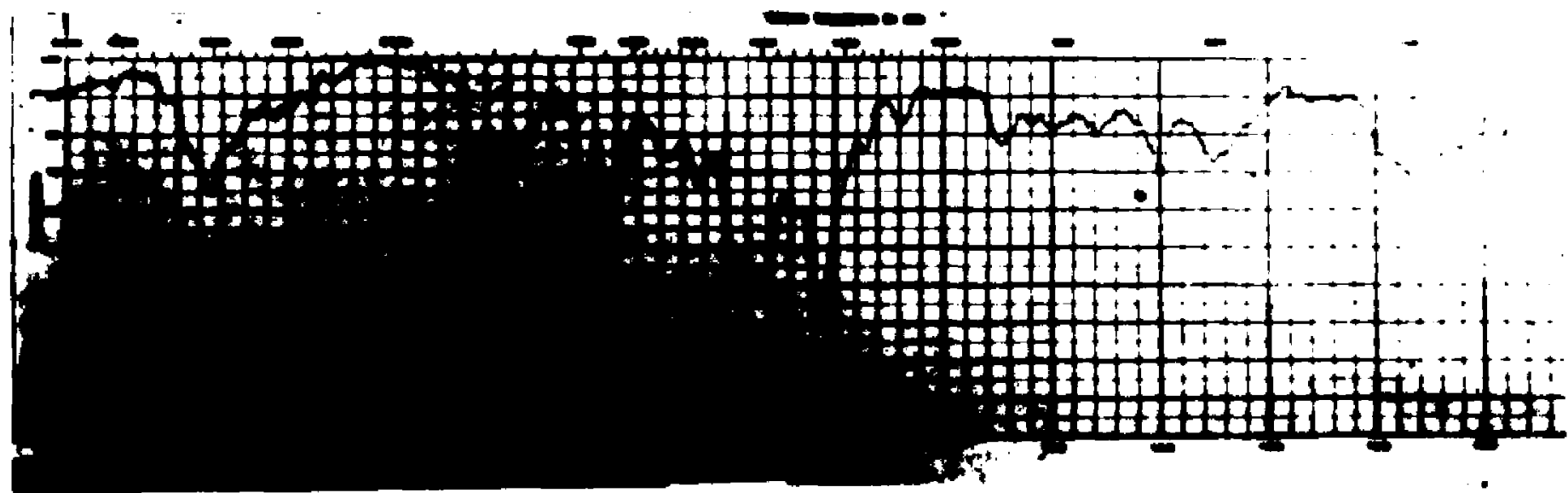

F1gure 14

Infrared Spootrum or 5-Phengleoetyl-Gontisic Aold

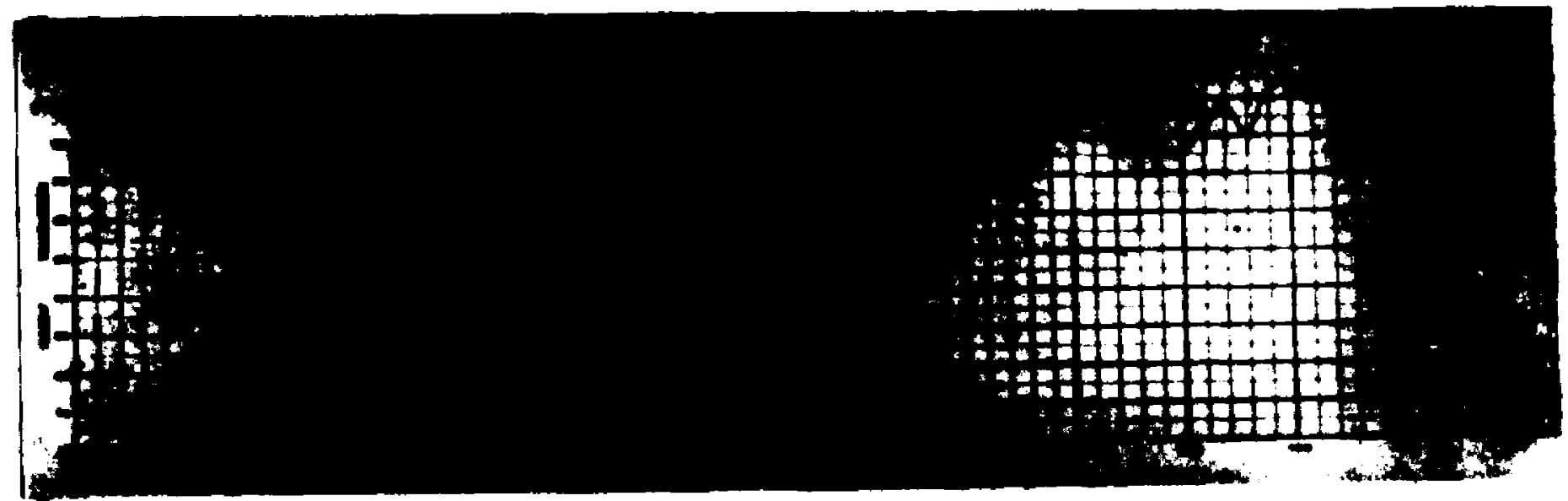

F1gure 15

Infrared spootrum of b-Paranitrobenzoyl-Gentialo hold 
Tablo IV.

Analyses of Infrared Spootra of Diethylami nopropanol bsters or Gentisio Aold

\begin{tabular}{|c|c|c|c|c|c|}
\hline $\begin{array}{l}\text { F1gure } \\
\text { Number }\end{array}$ & $\begin{array}{l}\text { Srnthet 10 } \\
\text { compound }\end{array}$ & Bolvent & $\begin{array}{l}\% \text { con- } \\
\text { centra- } \\
\text { tion }\end{array}$ & $\begin{array}{l}\text { Funotional } \\
\text { aroup }\end{array}$ & $\begin{array}{l}\text { Tharinum of } \\
\text { Absorption } \\
\text { by fupc- } \\
\text { tional } \\
\text { groups in }\end{array}$ \\
\hline 10 & $\begin{array}{l}\text { D10 thyl- } \\
\text { alnopropyl } \\
\text { Gentibate } \\
\text { HJdroohloride }\end{array}$ & Nujol & --- & $\begin{array}{l}\text { Aromatio } C-H \\
C=0 \text { in oster } \\
C=C \text { in benzene } \\
C_{6} H_{5}\end{array}$ & $\begin{array}{l}3.18 \\
6.00 \\
6.13 \\
6.75\end{array}$ \\
\hline 11 & $\begin{array}{l}\text { D1e thyl- } \\
\text { aninopropy } 1 \\
5-100 \text { tyl- } \\
\text { oentleate } \\
\text { Hydroohloride }\end{array}$ & $\mathrm{CHCl}_{3}$ & 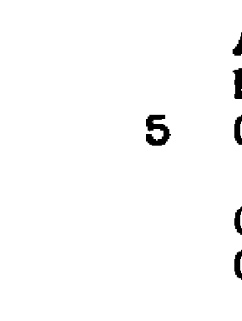 & $\begin{array}{l}\text { Aromatio } \mathrm{C}-\mathrm{H} \\
\mathrm{HC} I \\
\mathrm{C}=\mathrm{O} \text { in ester } \\
\mathrm{C}=\mathrm{C} \text { in benzene } \\
\mathrm{C}_{6} \mathrm{H}_{5}\end{array}$ & $\begin{array}{l}3.35 \\
4.22 \\
5.67 \\
5.92 \\
6.12 \\
6.72\end{array}$ \\
\hline 12 & $\begin{array}{l}\text { Diethyl- } \\
\text { am1nopiepyl } \\
\text { 5-methoxy } \\
\text { gentinate } \\
\text { Hydoohlor } 1 \text { de }\end{array}$ & $\mathrm{CHCl}_{3}$ & 10 & $\begin{array}{l}\text { O. In phenol } \\
\text { Aroma tio-C-H } \\
\text { HC } 1 \\
C=0 \text { in oster } \\
C=C \text { in benzene } \\
C_{6} \mathrm{H}_{5}\end{array}$ & $\begin{array}{l}3.10 \\
3.40 \\
4.18 \\
5.94 \\
6.15 \\
6.68\end{array}$ \\
\hline 13 & $\begin{array}{l}\text { D1e thjl- } \\
\text { aninopropjl } \\
\text { 5-Bensoyi- } \\
\text { oentioate } \\
\text { Hjdroohloride }\end{array}$ & $\mathrm{CHCl}_{3}$ & 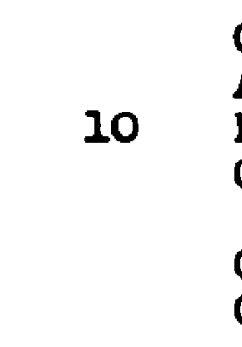 & $\begin{array}{l}\text { OH in phenol } \\
\text { Aromatio } \mathrm{C}-\mathrm{H} \\
\mathrm{HCl} \\
\mathrm{C}=\mathrm{O} \text { in ester } \\
\mathrm{C}=\mathrm{C} \text { in benzene } \\
\mathrm{C}_{6} \mathrm{H}_{5}\end{array}$ & $\begin{array}{l}3.08 \\
3.39 \\
4.23 \\
5.76 \\
5.82 \\
6.12 \\
6.72\end{array}$ \\
\hline
\end{tabular}




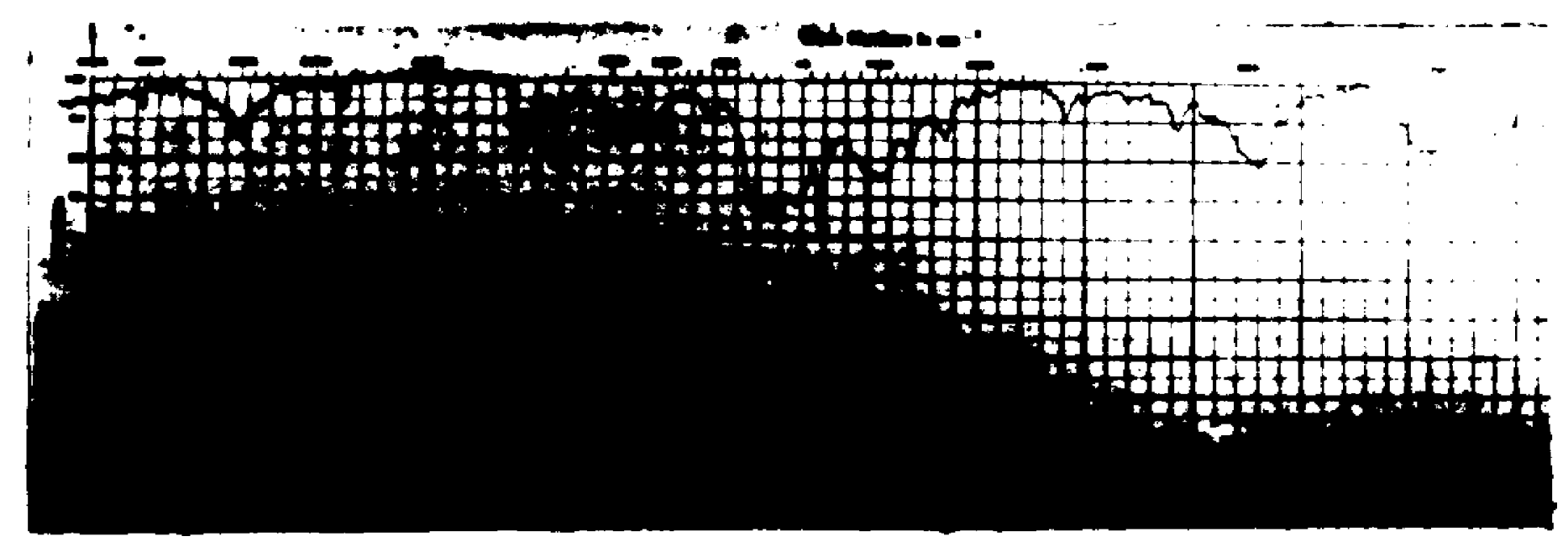

Pigure 16

Infrared spootrum of 5-An1syl-Gontisio Ao1d

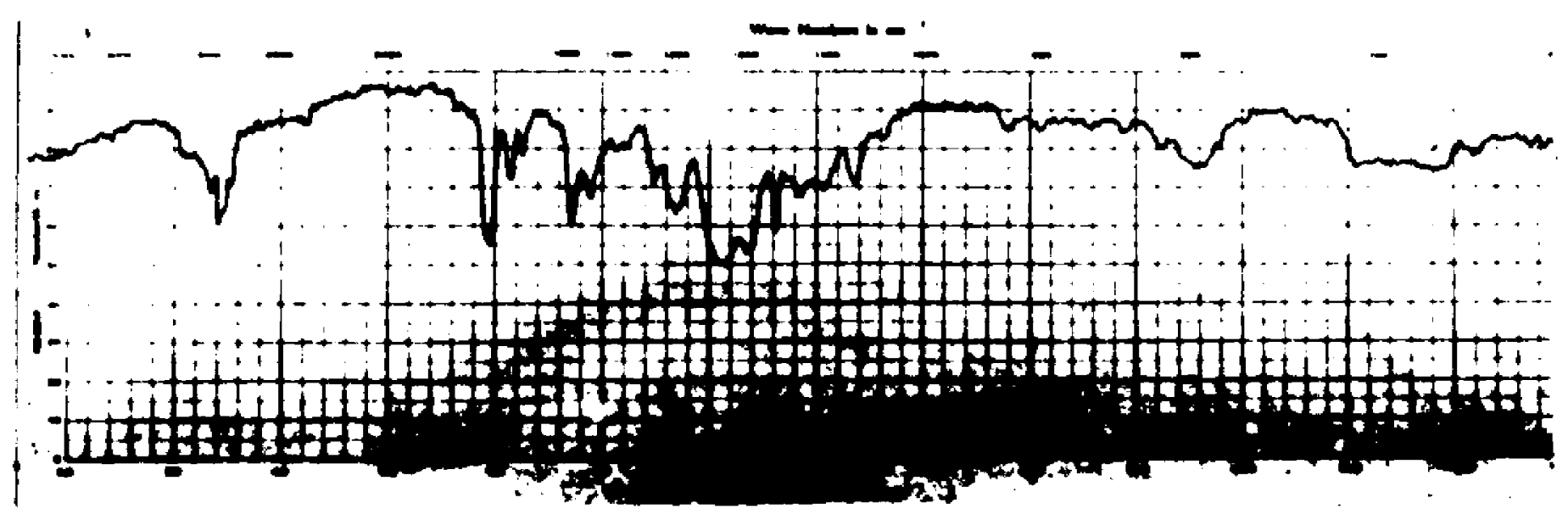

F1gure 17

Infrared Speotrum of 5-Aoetylaeliogl-Gentislo Aold

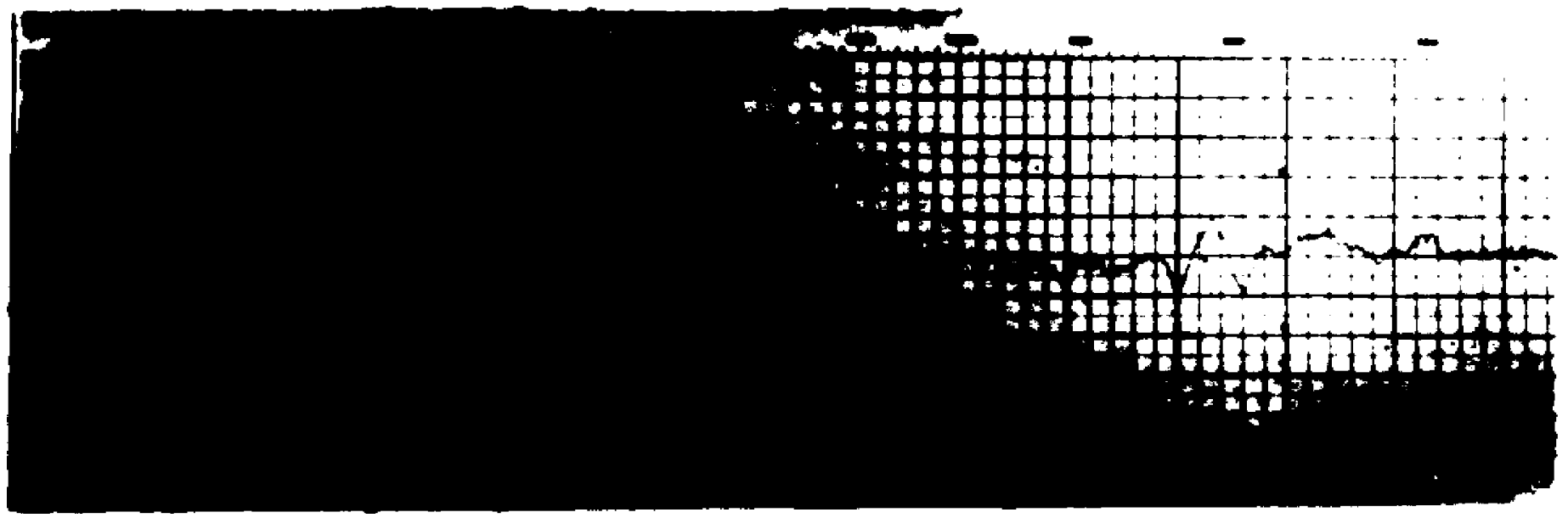

F1gure 18

Infrared Speotrum of 6,5 ' Suooinjl-D1gent1a10 Aold 
Table $\mathrm{V}$

Analyses of Infrared Spoctra of Fonollc kstoro of Gentisio Aold

\begin{tabular}{|c|c|c|c|c|c|}
\hline $\begin{array}{l}\text { P1gure } \\
\text { Iumber }\end{array}$ & $\begin{array}{l}\text { Synthot } 10 \\
\text { Compound }\end{array}$ & Solvent & $\begin{array}{l}\text { \% Con- } \\
\text { oentra- } \\
\text { tion }\end{array}$ & $\begin{array}{l}\text { Funotional } \\
\text { Groupa }\end{array}$ & $\begin{array}{l}\text { Maximum of } \\
\text { Absorption } \\
\text { by funo- } \\
\text { tional } \\
\text { groups in } \\
4\end{array}$ \\
\hline 14 & $\begin{array}{l}\text { 5-Phenjl- } \\
\text { coetyl- } \\
\text { Gentioio } \\
\text { dold }\end{array}$ & $\mathrm{CHCl}_{3}$ & 10 & $\begin{array}{l}\text { OH in phenol } \\
\text { Aromatio } \mathrm{C}-\mathrm{H} \\
\mathrm{C}=\mathrm{O} \text { in eater } \\
\mathrm{C}=0 \text { in acid } \\
\mathrm{C}=\mathrm{C} \text { in benzene } \\
\mathrm{C}_{6} \mathrm{H}_{5}\end{array}$ & $\begin{array}{l}2.93 \\
3.32 \\
5.67 \\
5.98 \\
6.12 \\
6.71\end{array}$ \\
\hline 25 & $\begin{array}{l}\text { 5-Paranitro- } \\
\text { benzoji- } \\
\text { Gontialo } \\
\text { Aold }\end{array}$ & $\mathrm{CH}_{3} \mathrm{OCH}_{3}$ & $\begin{array}{l}\text { Sat- } \\
\text { ur- } \\
\text { atod }\end{array}$ & $\begin{array}{l}\text { Arometio } \mathrm{C}-\mathrm{H} \\
\mathrm{C}=0 \text { in oster } \\
\mathrm{C}=0 \text { in oold } \\
\mathrm{C}=\mathrm{C} \text { in benzene } \\
\text { Nitro }\end{array}$ & $\begin{array}{l}3.35 \\
5.72 \\
5.92 \\
6.15 \\
6.48\end{array}$ \\
\hline 16 & $\begin{array}{l}\text { 6-Anideyl- } \\
\text { dentielo } \\
\text { Aold }\end{array}$ & $\mathrm{CHCl}_{3}$ & 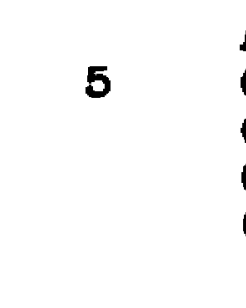 & $\begin{array}{l}\text { Arometio } \mathrm{C}-\mathrm{H} \\
\mathrm{C}=0 \text { in eater } \\
\mathrm{C}=0 \text { in acid } \\
\mathrm{C}=\mathrm{C} \text { in benzene } \\
\mathrm{C}_{6} \mathrm{H}_{5}\end{array}$ & $\begin{array}{l}3.36 \\
5.79 \\
5.95 \\
6.20 \\
6.62 . \\
6.75\end{array}$ \\
\hline 17 & $\begin{array}{l}\text { 5-Aoetyl- } \\
\text { aniogi } \\
\text { contialo } \\
\text { sold }\end{array}$ & $\mathrm{CHCl}_{3}$ & $\begin{array}{l}\text { Sat- } \\
\text { ur- } \\
\text { ated }\end{array}$ & $\begin{array}{l}\text { Aromatio } \mathrm{C}-\mathrm{H} \\
\mathrm{C}=0 \text { in acid } \\
\mathrm{C}=\mathrm{C} \text { in benzene } \\
\mathrm{C}_{6} \mathrm{H}_{5}\end{array}$ & $\begin{array}{l}3.35 \\
5.95 \\
6.15 \\
6.72\end{array}$ \\
\hline 28 & $\begin{array}{l}6,5 \text {, -3uooingl } \\
\text { D1gent1:10 } \\
\text { 101d }\end{array}$ & Nujol & $-\infty$ & $\begin{array}{l}C=0 \text { in eater } \\
C=0 \text { in aoid } \\
C=C \text { in benzene }\end{array}$ & $\begin{array}{l}5.65 \\
5.96 \\
6.08\end{array}$ \\
\hline
\end{tabular}


In I Igure 1 through 5 the infrared apeotra for known ocmpounds are chown. Tho two main foatures that are out- tanding in eaoh opootrum are the low tranamiasions in the 3.0 to 4.0 mioron range and the 5.6 to 6.0 mioron runge. In Ifure 1, the atrong absorption in these regions, ind 1oatec olearly a phonol10 group or groups and one oarboxyl10 aold runotion, respotivoly. However, in figures 2 through 5 whore the 5-phonolio funotion has substituted group on 1t, the nature of the absorption 1s markedly changed. Speolal attention lo oalled to Ilgure 4 booause it is a diab- t1 tuted phenolio oster. Howovor, hore the absorption in the 3.0 to 4.0 mioron range appearo very similar to that of r1gures 2,3, and 5. Th1s seems to indiogte the absorption pettern ohange is due to the substitution in the number rive poaition of gentisic aold.

In the rogion of 5.6 to 6.0 miorons of $f 1$ guras 2 and 5 two absorption "humpa" are prominent. One ropresents the - ater on the number five phenollo group and the other show the oarboxjl10 aold function. In flgure 4, this region 1 . noarly solid Ind loating very strong absorption due to the - ater and the oarboxyl10 aold groups. Figure 3 shows only the acid funotion, but the other does not ahow clearly becauso each sootrum ha atrong absorption in the 8.95 to 9.25 vioron region.

Sinoe the se two rogions, $1.0,3.0$ to 4.0 micron and 5.6 to 6.0 mioron, aro the only one of value for the interpre- 
tation of the known oompounds speotra, the unknowns oan be ovaluated onlj in the se regione.

Pigurea 6 to 13, inolualve, reprosent the oarboxyl10 no1d eater hjdroahlorides ajnthea1zed. In each apeotrum notioeable ohange of absorption has taken plaoe in the 3.0 to 4.0 mioron region, from thet of gentisio acid. It soems to Ind ion to from these traoings that any subatitution on the three funetional groupa greatly deoreases the absorption in the 3.0 to 4.0 mioron region.

Figure 6 ahow strong absorption at 3.40-3.50, 6.786.88 and 7.22 miarons. The atrong absorptions at these wave lengths are due to nujol and are prominent in figures 10 and 18 aloo.

The "onrbongl" region ahowe exaotly what one would prodiot from a look at the proposed atruoture of the synthelzed compounds. Flgures 6, 8, 10, and 12 show only one absorption maximum in the 5.6 to 6.0 mioron region. Th1s reprosenta the carboxyl10 aold oster group of these compounds. However, diethylaminoethyl 5-sootyl-gentisate hydrochloride, d10thylaminoethyl 6-bensoyl-gentisate hydroohlorldo, d1ethrlaninopropyl 5-aootyl-gentlaate hydroohloride and diothylaminopropyl 5-benzogl-gentias to hydroohloride (flgures 7. 9, 11, and 13 reapeotive1J) ahow two aboorption maxima In this rango. One peak is due to the ostor on number fivo phonol10 group and the other 18 due to the oarboxyl1c acid oster. 
F1gures 14 to 18 , inclusive, represent esters of the number flve phonolio hydroxy of gentisic acid.

In each of these compound the speotrum show a deoreased abeorption in the 3.0 to 4.0 mioron region, from that of the gent1e10 ac1d spectre.

The region of 5.6 to 6.0 mioron show two strong absorption bands in each apootrum with the exoeption of Figure 17. The flrat "hump" roprosonts the oster linkago at the number I1ve poaition of gentialc aold and the second represonts tho arboxyl10 aold funotion.

Figure 15 also shows the nitro group peak at a rave longth of 6.48 mloron.

F1gure 17, 5-noetglasiogl-gentisic acld shows only one oarbonyl group, whioh 1s lookted at 5.95 miorons. Th1s indioates no osterifioation at tho number 5 hydroxyl position of gent1010 ao1d. However, the absorption spectrum of the oompound 1a greatis different from that of gentisic acid eapooially in the 3.0 to 4.0 mioron rango. Therefore, although tho apeotrum indiontes no phonolic aster, it is believed thet Figure 17 represents the apootrum of a now ger tialo ao1d derivative.

From the analyaes of the spectra, the faoto indicate that the roaction botween dialkylaminoalkyl ohlorides and gentio10 aold j1elded dialkylaminoalkyl gentlsate hydroohlorides, and the raaotion botwoen gontisio acid and the ao1d ohlorides of the peolried aolde yielded the 5-phenol10 esters of gentialo noid. 
Toxio1ty Testa

Every compound thought to be of modicinal value must be coreened pharmaoologloally to determino its activitj. one of the rirst and most important stops in this process 1. the determination of 1 ts toxiolty. The usual mothod of oxprosaing toxiolty is in terms of the dose that k1lls 50\% or a large group of animals, or the to $50^{\circ}$ The term $L_{50}$ is the abbroviation for "lethal dose to 50\%". The term applies for aoute or ohronic toxiolty testa. The aouto toxicity roferg gonerally to doaths that oocur within 24-48 hours after adminiatration of the drug. Chronic toxicity studies extend over a perlod of weeks, followed by autopsy of the animal to determine what tissues and organs,. If any, are arrootod.

The carboxyl10 acld otors belng water soluble were administered intrevenousig.

The phenolic eatera were prepared as follows and administored intravenously. The material was dissolved in aloohol, 3\% Tween 80 was added, and the m1xture wes added to water whioh oontained not more than 5\% acacia. The total aloohol oontent was not more than $5 \%$.

Propylone glyool and polyethylene glyool disolved the phonol1c esters, but both olventa were toxic when udministered in doser as low as 0.1 ml. per mouse, hence, oould not be uned.

The teohnique used in these tosts was as follows: 


\section{0}

1. Swiss mice from the same sour oe of supply, welighing from $10 \mathrm{~g}$. to $28 \mathrm{~g}$. were used. Theg were in good health and had beon kopt under observation for at lasst 3 days prior to their uso. They wore housed in standard cages in a room reletivoly constant in so far as temperaturo and numidity are conoerned. Their diet consisted of an unlimited ration of water and Purina Dog Chockers.

2. The solutiona wore injected by means of a $1 \mathrm{ml}$. tuboroulin ayringe and a 25 gisage, 1 inch needle.

3. Al1 doseg administered were on a $\mathrm{mg} . / \mathrm{K}_{\mathrm{g}}$. basis.

4. The m100 were starved 24 hours to otaniardize their motabol1sm.

5. The solutions were given slowly into the tall velns of the mouse.

6. In oach group of esters, 1.0. curboxyl1c acid and and phonolio, it was nooossary to first find the toxiclty range. The other compound in a group were found to $f a l l$ within thia toxic range.

7. The ossential requirements for Behren's method of statistioal ovaluation were met so the $I D_{50}$ 1a reportar and grapha drawn uoling this integrated data (70). 
Toxic1ty of Carboxylic Ac1d Eaters of Gentisic Acid

Taile VI

ID 50 of Diothylaminoethyl Gentiag te Hydrochloride Bxporimontal Data Integrated Data

No. of Dose

$\%$

$\%$

animal. mg/Kg Al1ve Dead Mortality

$\begin{array}{rrrrrrrr}12 & 10 & 12 & 0 & 0.00 & 31 & 0 & 0.00 \\ 12 & 30 & 11 & 1 & 8.35 & 19 & 1 & 5.00 \\ 12 & 50 & 6 & 6 & 50.00 & 8 & 7 & 26.67 \\ 12 & 70 & 2 & 10 & 93.45 & 2 & 17 & 89.47 \\ 12 & 10 & 0 & 12 & 100.00 & 0 & 20 & 100.00\end{array}$

ID 50 equala $51.2 \mathrm{mg} / \mathrm{Kg}_{\mathrm{B}}$.

\section{Table VII}

ID 50 of D10 thylaminoethyl 5-Àcetyl-Gentiate Hydrochloride Experimental Data Integrated Data

No. of Dose animala mg/Kg Al1ve Doad Mortal1ty Al1ve Dead Rortal1ty

$\begin{array}{rrrrrrrr}12 & 30 & 12 & 0 & 0.00 & 31 & 0 & 0.00 \\ 12 & 40 & 10 & 2 & 16.67 & 19 & 2 & 9.53 \\ 12 & 50 & 4 & 8 & 66.67 & 9 & 10 & 52.63 \\ 12 & 60 & 5 & 7 & 58.33 & 5 & 17 & 73.02 \\ 12 & 70 & 0 & 12 & 100.00 & 0 & 29 & 100.00\end{array}$

L50 oquala $51.5 \mathrm{mg} / \mathrm{Kg}$.

Table VIII

Log of Diethylanimoethyl 5-We thoxy-Gentisate Hydrochior Ide Exporimental Data

Integrated Data

No. of Dose \% $\%$ Anima 10 mg/Kg Al1vo Dead Mortglity Al1vo Dead Mortality

$\begin{array}{rrrrrrrr}12 & 10 & 12 & 0 & 0.00 & 32 & 0 & 0.00 \\ 12 & 20 & 11 & 1 & 8.35 & 20 & 1 & 4.76 \\ 12 & 30 & 5 & 7 & 58.33 & 9 & 8 & 47.06 \\ 12 & 40 & 4 & 8 & 66.67 & 4 & 16 & 20.00 \\ 12 & 50 & 0 & 12 & 100.00 & 0 & 28 & 100.00\end{array}$

$\mathrm{I}_{50}$ equala $32.2 \mathrm{mg} . / \mathrm{Kg}_{\mathrm{g}}$. 
82

Table IX

D $_{50}$ of D10 thylaminoethyl 5-Benzoyl-Gentisate Hydrochloride Exporimontal Data

Integrated Data

No. of Dose

enimale ma/Ka Alive Dead Mortality

$\begin{array}{rrrrrrrr}12 & 10 & 12 & 0 & 0.00 & 25 & 0 & 0.00 \\ 12 & 30 & 9 & 3 & 25.00 & 13 & 3 & 18.75 \\ 12 & 50 & 4 & 8 & 66.67 & 4 & 11 & 73.23 \\ 12 & 70 & 0 & 12 & 100.00 & 0 & 23 & 100.40\end{array}$

$\mathrm{DS}_{50}$-quals $41.3 \mathrm{mg} . / 18$.

Table $X$

D $_{50}$ of Diethylaminopropyl Gentisate Hydrochloride Experimental Data

Intagrated Data

No. of Dose $\%$

animals $\mathrm{mg} / \mathrm{Kg}$ Alive Dead Mortulity

$\begin{array}{rrrrr}12 & 30 & 12 & 0 & 0.00 \\ 12 & 50 & 8 & 4 & 33.33 \\ 12 & 70 & 3 & 9 & 75.00 \\ 12 & 90 & 0 & 12 & 100.00\end{array}$

$\mathrm{ID}_{50}$-quala $58.5 \mathrm{mg} . / \mathrm{Kg}$.

Table XI

D $_{50}$ of Die thylaminopropyl 5-Acetjl-Gentiate Hydrochloride Experimontal Data

Integrated Data

No. of Dose

animalo mg/xg Alive Doad Mortality

$\begin{array}{rrrrrrrr}12 & 30 & 12 & 0 & 0.00 & 23 & 0 & 0.00 \\ 12 & 40 & 5 & 7 & 58.33 & 11 & 7 & 38.38 \\ 12 & 50 & 4 & 8 & 66.67 & 6 & 15 & 71.43 \\ 12 & 60 & 2 & 10 & 83.33 & 2 & 25 & 92.59 \\ 12 & 70 & 0 & 12 & 100.00 & 0 & 37 & 100.00\end{array}$

$\mathrm{LD}_{50}$ equala $43.8 \mathrm{mg} . / \mathrm{Kg}_{\mathrm{g}}$ 
83

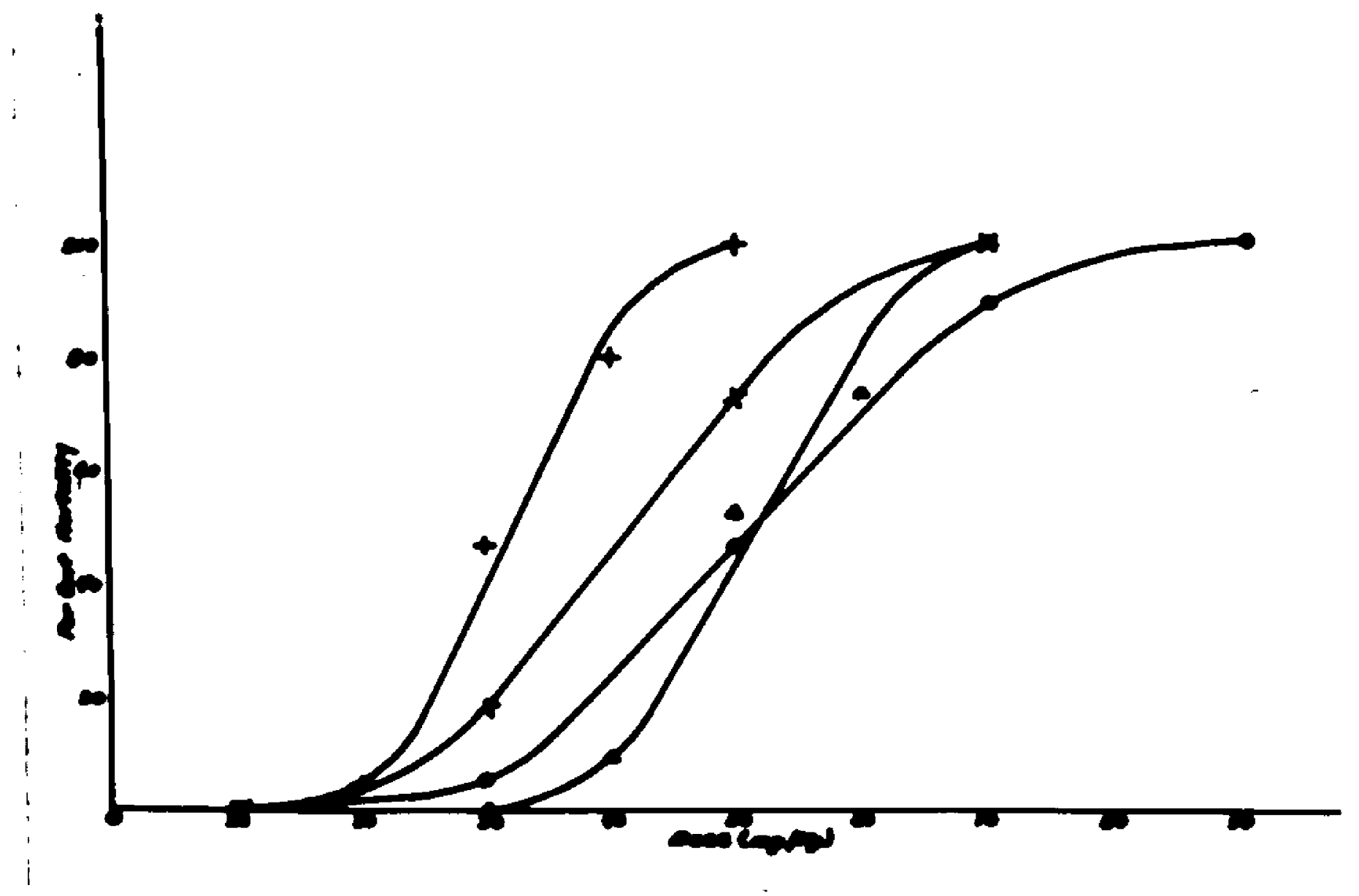

F1gure 19

Graph of $\mathrm{ID}_{50}$ of Diethylaminoothyl Eaters of Gentisic Acld and Subatituted Gentisic Ac1ds

O Die thylaminoethyl Gentisate Hydrochloride

- Dlo thylaminoe thyl 5-A0otyl-Gent1sate Hydrochlor ldo

+ Die thylaminoe thyl 5-Mo thoxy-centiaate Hydrochloride

$x$ Dlo thylaminoethyl 5-Benzoyl-Gentisate Hydrochloride 
Table XII

ID $_{50}$ of Diethyluminopropyl 5-Me thoxg-Gentiate Hydrochloride Experimental Data Integrated Data

No. of Dose $\%$ \% Animala mg/Kg Alive Doad Mortalitr Al1vo Doud Mortal1ty

$\begin{array}{rrrrr}12 & 10 & 12 & 0 & 0.00 \\ 12 & 20 & 7 & 5 & 41.67 \\ 12 & 30 & 2 & 10 & 83.33 \\ 12 & 40 & 1 & 11 & 91.67 \\ 12 & 50 & 0 & 12 & 100.00\end{array}$

$\mathrm{ID}_{50}$ oquala $22.0 \mathrm{mg} . / \mathrm{Kg}$.

Tablo XIII

L $_{50}$ of Diethylaminopropyl 5-Benzoyl-Gentisate Hydrochloride Experimental Data Integrated Data

No, of Dose Animala mg/Kg Alive Dead Mortality

19.

12

12

12

12

12

20

120

111

66

0.00

30

35

210

8.33

o 12

50.00

83.33

40

100.00

$\begin{array}{rrr}22 & 0 & 0.00 \\ 10 & 5 & 33.33 \\ 3 & 15 & 93.32 \\ 1 & 26 & 96.29 \\ 0 & 38 & 100.00\end{array}$

I $_{50}$ oqual. $30.2 \mathrm{mg} \cdot / \mathrm{Kg}_{\mathrm{g}}$. 
85

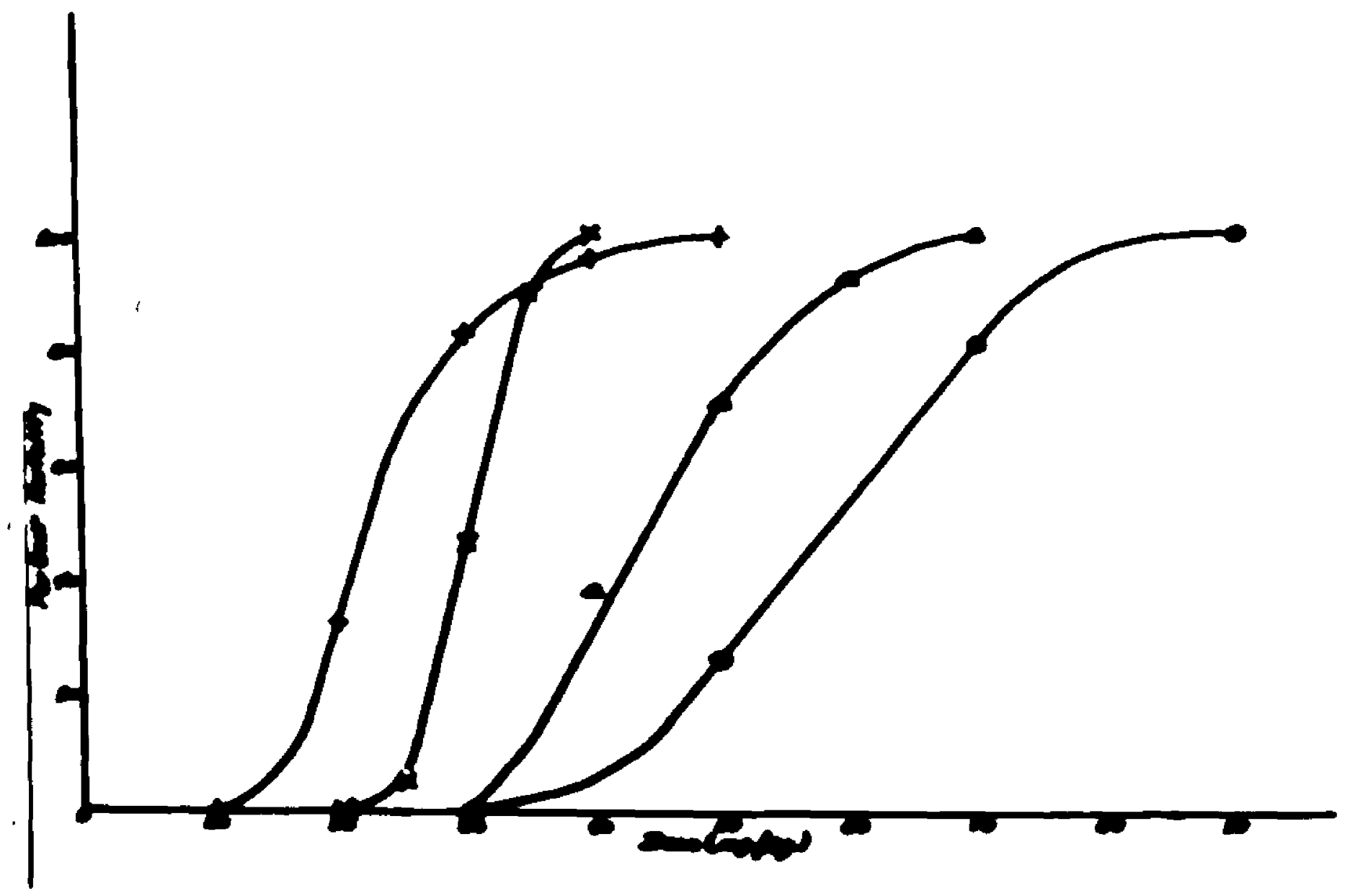

F1gure 20

Graph of T50 of Diethylaminopropyl Eisters of Gentisic Acld and Substitutod Gontisic Acids

- Die thylaminopropyl Gentisate Hydrochloride.

A D10 thylaminopropyl 5-Acotyl-Gentisate Hydrochloride

+ Dio thylaminopropyl 5-Mo thoxy-Gentisatr Hydrochlurido $x$ Diethylaminopropyl 5-Benzoyl-Gentisate Hydrochloride 
The least toxio oompound of the oarboxyl1c acid ester hydrochlorides wal diethylaminopropyl gentioate hydroohlor 1de $\mathbf{w t h}$ a $\mathrm{ID}_{50}$ or $58.5 \mathrm{mg} . / \mathrm{K}_{8}$. and the most tox $1 \mathrm{c}$ compound was diethylaminopropyl 5-me thoxy-gentlate hydrochlor1de wth $^{\mathrm{th}} \mathrm{ID}_{50}$ of $22.0 \mathrm{mg} . \mathrm{K}_{\mathrm{B}}$.

Generally, the diethyleminopropanol oater hydrochlorides are more toxio than the die thylaminoethanol counter-parts. However, the firot mombers of the sorles aro roversed in this respeot. These oompounds follow the generul pattern or Inoreased oarbon ohain inoreases toxicity.

The methoxy group show 1t's noted toxicity by being the moat toxio eater in both the diethylaminoethanol and d1e thylaminopropanol aerios.

The 5-benzogl and 5-aoetyl dorivatives of the aminoaloohol enter hydroohlorides are $200 \mathrm{~s}$ toxic then the 5-methoxy derivative.

Apparently the toxiolty of these compounds is due prinolpalis to the eminoloohols bocause the parent compousds are relatively non-toxio.

The w100, that died, went into convulsions and died whin a minute after the compound was injooted. No deatho ooourred after 5 minutes from the timo of injeotion. 
Toxiolty of Phonolio buterg of Gentisic Ac1d

Tablo XIV

ID $_{60}$ of 5-Phenylaoetio-Gent1sio Aold

Bxporimental Data

Integrated Data.

No, of Dose $\%$ \%

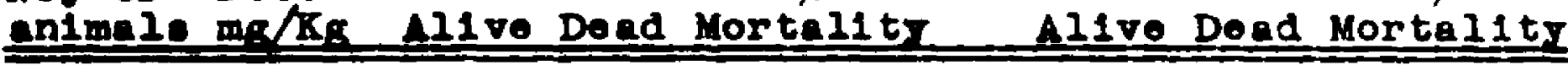

$\begin{array}{rrrrrrrr}12 & 160 & 12 & 0 & 0.00 & 31 & 0 & 0.00 \\ 12 & 180 & 9 & 3 & 25.00 & 19 & 3 & 14.29 \\ 12 & 200 & 6 & 6 & -60.00 & 10 & 9 & 47.37 \\ 12 & 220 & 4 & 8 & 66.67 & 4 & 17 & 80.96 \\ 12 & 240 & 0 & 12 & 100.00 & 0 & 29 & 100.00\end{array}$

$\mathrm{H}_{50}$ equa18 201.2 $\mathrm{mg} . / \mathrm{K}_{\mathrm{g}}$.

Table XV

L50 of 5-Paranitrobenzogl-Gentialc Acid

Bxporiwontal Data

Integrated Data

No, of Dose to \%

animele mg/Kg $411 \mathrm{ve}$ Dead Mortal1ty Al1ve Doad Mortality

$\begin{array}{rrrrrrrr}12 & 30 & 12 & 0 & 0.00 & 39 & 0 & 0.00 \\ 12 & 50 & 9 & 3 & 25.00 & 27 & 3 & 10.00 \\ 12 & 70 & 9 & 3 & 25.00 & 18 & 6 & 25.00 \\ 12 & 90 & 7 & 5 & 41.67 & 9 & 11 & 55.00 \\ 12 & 110 & 2 & 10 & 83.33 & 2 & 21 & 92.17 \\ 12 & 130 & 0 & 12 & 100.00 & 0 & 33 & 100.00\end{array}$

L50 equale $83.5 \mathrm{mg} . / \mathrm{Kg}$.

Table XVI

ID $_{50}$ of 5-Aniayl-oontisio Ao1d

ixporimontal Data

No. of Dose \%

enimale pe/Ka slive Dead Mortality

18

12

12

12

18

18

$\mathrm{ID}_{50}$
80

30

40

50

60

70
12

10

5

6

3

o 12

0

2

7

6

9

0.00

16.67

58.33

50.00

75.00

100.00

\footnotetext{
-quala $44.9 \mathrm{mg} . / \mathrm{Kg}_{\mathrm{g}}$
}

Intogratod Data

9

Alive Dead Mortality

36

24

14

$8 \quad 15$

324

o 36
0.00

7.68

39.13

62.50

88.88

100.00 
TABIS XVII

ID $_{50}$ or 5-Aoetylsalloyl-Gentisic Aold

Exporimontal Data

Intograted Date

No. of Dore

aninale ma/Kg Alive Doad Mortalit

\begin{tabular}{|c|c|c|c|c|c|c|c|}
\hline $\begin{array}{l}12 \\
12 \\
12 \\
12 \\
12\end{array}$ & $\begin{array}{l}20 \\
20 \\
30 \\
40 \\
50 \\
60\end{array}$ & $\begin{array}{r}12 \\
9 \\
7 \\
4 \\
1 \\
0\end{array}$ & $\begin{array}{r}0 \\
3 \\
5 \\
8 \\
11 \\
12\end{array}$ & $\begin{array}{r}0.00 \\
25.00 \\
41.67 \\
66.67 \\
91.67 \\
100.00\end{array}$ & $\begin{array}{r}33 \\
21 \\
12 \\
5 \\
1 \\
0\end{array}$ & $\begin{array}{r}0 \\
3 \\
8 \\
16 \\
27 \\
39\end{array}$ & $\begin{array}{r}0.00 \\
12.50 \\
40.00 \\
76.18 \\
96.43 \\
100.00\end{array}$ \\
\hline
\end{tabular}

$\mathrm{ID}_{50}$ oquala $32.4 \mathrm{mg} . / \mathrm{Kg}$.

TABLE XVIII

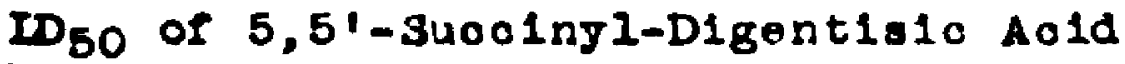

Experimontal Data

Intograted Data

No. or Dose \%

animale mg/Kg Alive Doad Mortality

Al1ve Dead Mortality

$\begin{array}{rrrrrrrr}12 & 100 & 12 & 0 & 0.00 & 28 & 0 & 0.00 \\ 12 & 130 & 8 & 4 & 33.33 & 16 & 4 & 20.00 \\ 12 & 160 & 6 & 6 & 50.00 & 8 & 10 & 55.55 \\ 18 & 180 & 2 & 10 & 93.33 & 2 & 20 & 90.91 \\ 12 & 220 & 0 & 12 & 100.00 & 0 & 32 & 100.00 \\ D_{60} & \text { 9quals } & 155.0 \mathrm{mg.} / \mathrm{K} . & & & & & \end{array}$

TABIE XIX

ID $_{50}$ or Gentisic Aold

Ixporimontal Data

Integrated Data

No. of Dose $\%$ \%

animala ma/Ko Mlive Dead Mortality Al1vo Doad Mortality

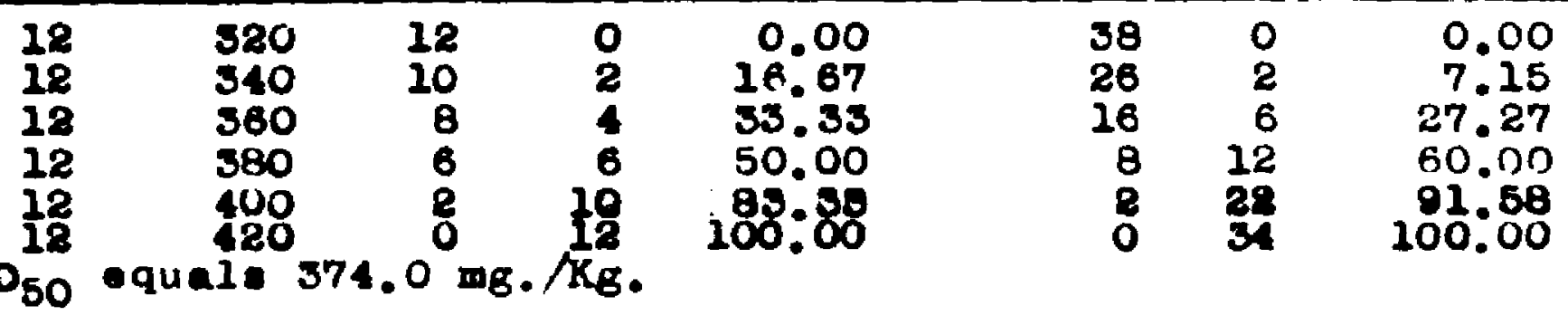




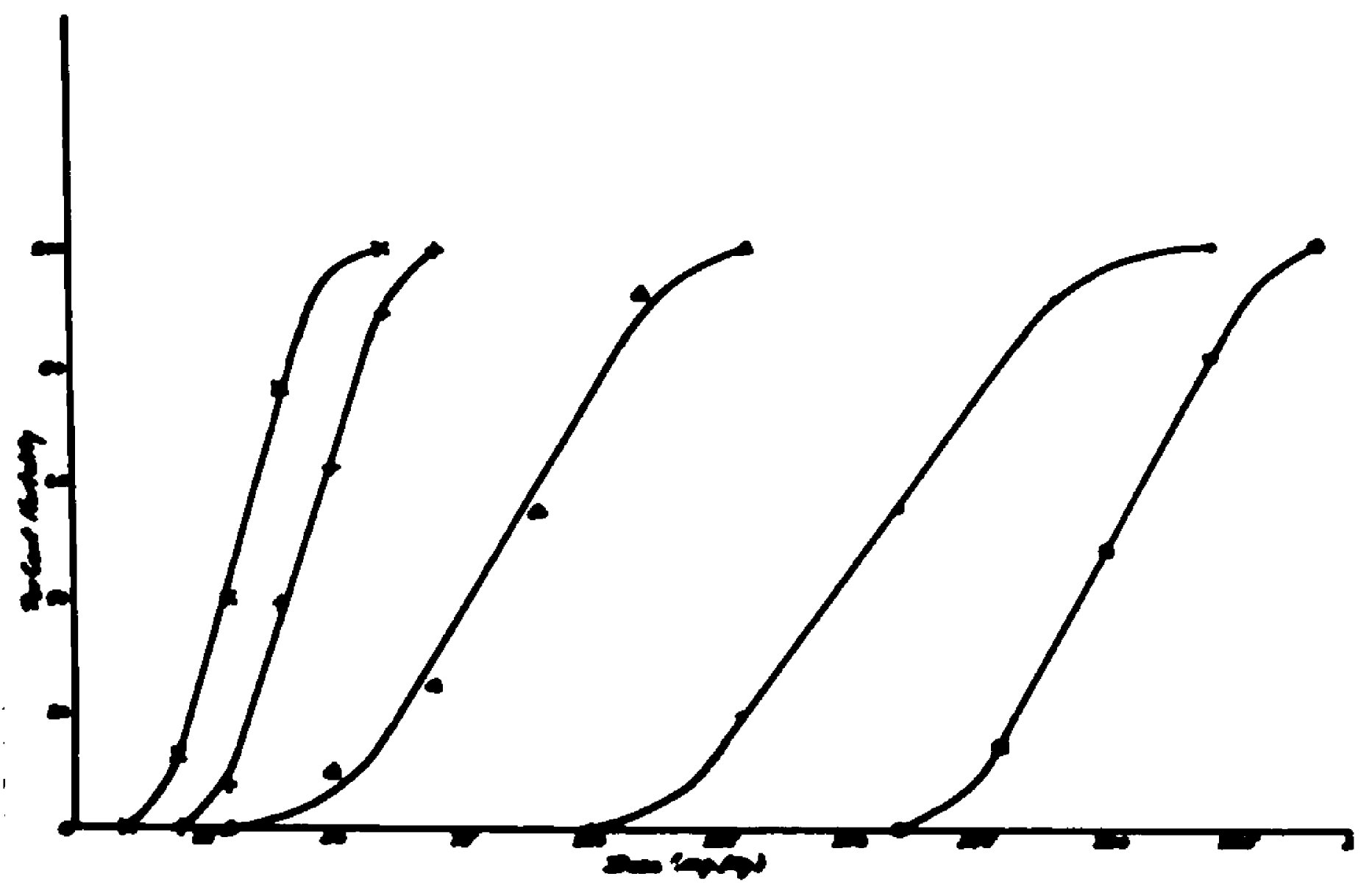

F1are 81

Oraph of IDso of Phonolio Betere of Gentiale 101d

o 5-Phonjleetjl-0ent1a10 Ae1d

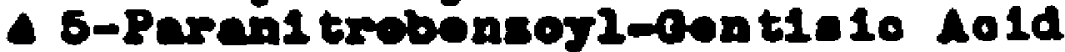

+ 8-nirejl-gent1e1e celd

$x$ b-10otjiealiogl-oont ic 1o 101d

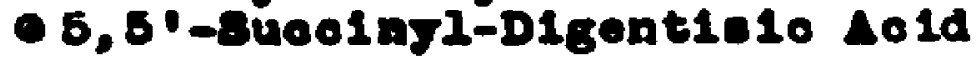


90

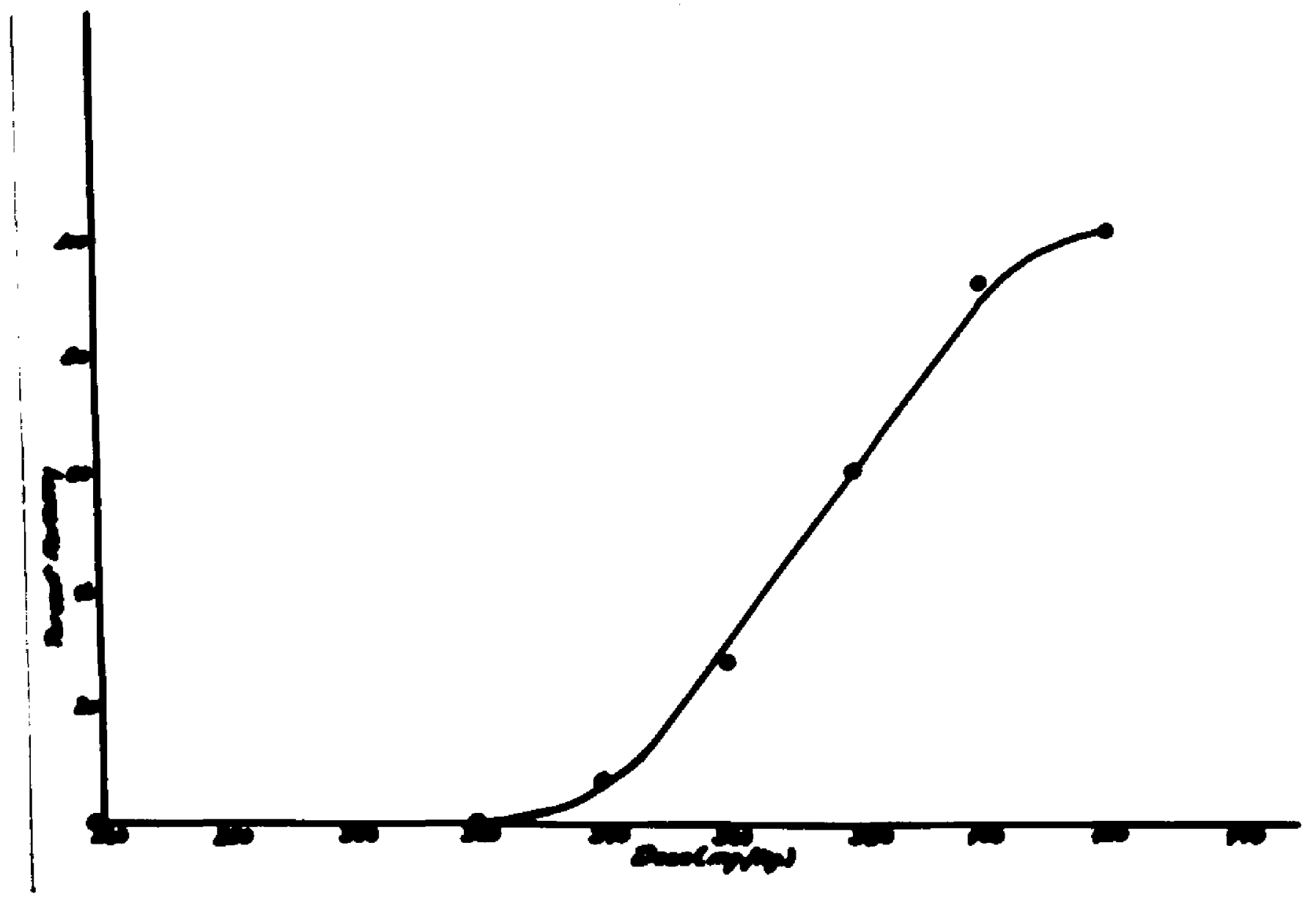

F1gure 22

Gruph of $\mathrm{ID}_{50}$ ce Gentia10 Aold. 
The phonolic oaters vary in toxiolty from $32.4 \mathrm{~m}$ for 5-aoetylaaliogl gontisic acid to $201.2 \mathrm{mg} . / \mathrm{Kg}$. for $5-$ phenglaoet10-gent1s10 ac1d.

The Inorease in toxiolty of these oompounds over that or gentialo acid may be attirubuted to the inherent toxicity of aubstituted funotional group, 1.0. paranitrobenzcyl and anlogl. However, the 1noreased aoldity of the compound may also be partially responsible for 1 ts 1 ncreased toxicity. Groups on the benzene ring of the substituting function appears to Inorease the toxiolty of the compound.

The phenolio orters oaused convulgions before doath in the mioe killod. However, the action of these compolinds was -lower, generally roquiring several minutes to kill the animal injooted.

s1nce LD $_{50}$ for gentisic ac1d was found to be 374.0 mg./Kg.. Intravenously, and the ${ }^{2} D_{50}$ reported for sodium gentlate was $3.1 \mathrm{mg} . / \mathrm{Kg}_{\mathrm{g}}$, Intraperitioneal (36), the toxlo1ty of the osters agnthosized is considerably greater than Eentialo aold or 1ta sodium salt. 'The toxiolty of these oompounds 1s also greater than that reported for sodium

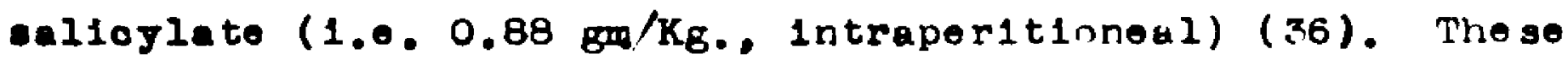
roportod value wore dotermined on rats and seom high oompared to that whioh was found for gent1sio acid intravenously. Generally, the toxiolty of phenollo esters 18 lower then that of the oarboxylio aold osters. This may be due to the 
faot that the former types wore given in suspenglons whereas the latter were aquoous colutions.

Due to the higher toxiol ty of the prepared products, they w1Il neod to have considorably more activity than gentisio aold to bo of groator value modiolnally.

No ohronic toxicity studies of these compounds ware made, but from obaerving the animals injocted on a given day. It wa noted that no deatho occurred after 5 to 10 minutes from the time of injection.

If these oompounds have analgesic value, theg would probably bo adminlatered orally, 1.0. as tablet or powder. oral toxiolty 1a muah lower than intravanous tnotolty so the therapoutic index of the compound may bo botter than the resulta show. 


\section{Summary}

Attompto woro made to synthosizo soveral anino tlcohol ester hydroohlorides of gent1sic aold. From the attempts -1ght new compounds were formed. It was found that the roaotions betwoen the chlorides of the alcohols and the free acids gave the bost ylelda and aparently the most nearly pure produots. It was also observed that in the cise of the suocosarul reactions the intermediate halides had beon reported in the 11terature, whereas in the cases where unreported intermediates had to be used, the ylelds were poor and the products of douvtrul purity.

The flve phonolio oaters were propared succossfully by the sohotten-Baumen rection. The yields were jood and the producta rolatively pure. The acid chlorides wore prepared by the use of thionyl ctiloride and the properties of these aoid oblorides were found to be of the same nature as liter ature reported values.

The reaction between the anid chlorides and gentisic ao1d, ueing pyridine or dimethylaniline as a condensing modium, was not auocessful. It 1o belleved that the pyridino or dimethylaniline was not strong onough to remove the hydrogen from the phonolio hydroxide and the chlorine from the eoid ohloride.

To prove the al to whioh ostorifiation took place on gontiolo ac1d, when the acid and the hollde or acid chloride 
wore reaoted, two qualitative procedures and one quantitutive toohnique wero utilized. The first qualitative test was the ferrio ohloride oolor test. The tost ylelds a derk blue ooloration for orthohydroxyl oarboxyl10 acids, but a negat1vo test with motahydroxyl oarboxyl10 aold and substituted orthohydroxyl oarboxyl1c ac1d osters. Therefore, since all the eaters give a positive test, 1t 1s indicative that the number 2 hydroxyl group of gentialc acid wes free.

The seoond qualitative proof of the point of esterifioation was the determination and analysis of the infrared apeotrum of the compound. By comparing the spectrum of the synthesized compound to that of known compounds, it is oasy to see whether one or two oarbonyl functions are present. Gentisic acid show one carbonyl and carboxylic acid estors or gentisic nold also show only one carbonyl funotion when the number 5 hydroxyl 1s froe or is blocked by gn ether 11nkage. However, for those carboxylic acid osters that also have noetyl or benzoyl function in number 5 postion of gent1a1c ac1d, two carbonyl groupare looated on adch spectrum. All tho spectra of the phonolio esters show two curbonyl funotions present, one 18 due to the oarboxylic acid Eroup or gent1s10 ao1d and the other is due to the oster at number 5 position of the acid.

The quantitative proof of esterifloation was determired by the noutral equivalent procedure. The phenollo esters were titrated diroctly with base and the carboxylic acid 
oster hydrochlorldes were titrated with base, liberating, the amine and the amine was agaln converted to the salt by aoldio titration. The molocular wolghts are food for tho phenol10 eaters exoept for 5-acetylselicyl-gentisic acid. The woleoular weight determinations for the carboxylic acid - ater hydroohloridos range from good to satiafactory. Better roaults oould have been obtalnedif a larger aumple of ejnthet1o oompound and microburettes had been used.

The unreative nature of the number 2 hydroxyl group of gontisio acid lo attributed to strong hydrogen bonding betwoen the hydrogen of the hydroxyl group and the carvonyl or the ac1d group, and to the eleotron offect, 1.A. the numbor 5 hydroxyl group supplies electrons to the ring ospeolally ortho and para, thus hindering the removal of the hydrogen of the number 2 hydroxyl. However, the latter effoot may be offaet by the meta direoting oarboxylic acid funotion or tho to the hydroxyl group in question.

The only synthesized compound the formula of whioh is in doubt is that of 5-acotyloalioyl-gentisic acid. The two outatanding disorepanoles botween the proposed and the actual atruoture of the oompound are the molocular wolght and the Infrared pectrum. Tho carbon and hylrogan analysia also shows the found oarbon to be ahout $1 \%$ higher than the caloulated amount for 5-acetylsalicyl-gentlsio ao1d. However, the author believes the compound to be a new synthetic derivative of gentiolc aold. Th1s is supported by the fucts 
that the Infrared spoctrum, noutral equivalent and carbon and hydrogen analysis are all very different from those of tho paront compounds. Tho following may explain the disorepanciess The product was propared by the interaction of aoetyloalioyl ohloride nd gentiolc acid in basic modia. The acld ohloride was propared as previously roported in tho 11terature. The acid ohloride produced had the accepted physioal proportios. It is known that aootyl groupa aro most oasily hydroljaized in basio solution. Therefore, the poesibility exista that ol ther before or aftor tho desired oaterifloation took place, hydrolysis of the acetyl group of aootylealiojl ohloride was brought about. The canround produoed, therefore, may bo 5-aalloyl-gentlsio acid. The moleoular welght of the oompound, $1.0 .274 .22 \mathrm{~B} .$, is more noarly equal to the found molooular we1ght, $285.23 \mathrm{~g}$, than 1. the moleoular weight of 5-acotylanileyl-gentisic acid, 1.0. 316.26 g. The oarbon ad hydrogen analyais is aloo more nearly oorroot: Calculated for $\mathrm{C}_{14} \mathrm{H}_{10} 0_{6}: \mathrm{C}, 61.31$; H, 3.63: Found: C, 61.74, 61.53; H, 3.92, 3.86. The assumption that the new oompound 1o aotualiy 5-salicyl-gentisio eo1d also may explain why only one oerbonyl funotion shows on the Infrared speotrum of the oompound. It may be that the hydrogen bonding between the hydroxyl funotion of the anllojl radioal and the oarbongl funotion of tho oater group 1. too atrong to be deteoted. Thorefore, only the carboxyl10 funotion of gentialo aold how in the spotrum. 
The relative high toxiolty of the oarboxylic acid ostor hydroohlorides appoars to be primar1ly due to the amino aloohol portion of the moleoules. However, the groups In number 5 pooition of gontisic ac1d do exert some influenoe in the eo eaters, ospeolally the mothoxy group. The mothoxy group 1s notod for 1 ts toxio naturo and both derivative oontaining thls groupling are the most toxic of the ir eerios.

The 1noreased length of chain, 1.0. - thyl to propyl, of the aloohol, also inoreases toxicity as one would oxpect. The toxiolty inorease of the phenolic esters over that of gontialo aold may be because of the 1noreased acid etrength of tho compound. The inoreased acidity is brought about by the roplaoement of the ortho-para direoting hydroxyl group by the meta direoting ester function. The functional groupe added also play thelr purt beoquse the nitro and methoxy containing compounds are the most toxic of the serles. The 5-aoetylaallogl-gent1sio aold appeared to be much more toxio than one would prodiot. Th1s unoertainty again ind 1cated thet the proposed struoture may be incorreot.

$\Delta 11$ the esters of gontisio acid wero prepared with the hope of produoing now and bettor drugs. The oyntheses were planned from the point of viow of oombining two medicinally aotive nuole1 to form a compound more active than a phyalcal mixture of the ocmpounds. S1noe the roating compound s have anelgetio and antirhounatso aotivity, it ls boliovod that 
the ofnthosized compounds should have aotivity of the same neture. The posolb1lity also exists that the oartoxyl10 aold oter hydroohlorides w11l have looal anoothetic and/or ant1spanod 10 aotivity. Tho phonolio oatore may also bo beoterioldal in nature.

The value of these oompounds will bave to be determined by phamaoologionl to ating before the true modiolnal value of the ejnthotios oan be otated. If notivity 1a ahown by tho arboxyl10 ao1d osters, It is auggeated that othor active ocapound maj be preparod bJ altering the amino aloohol ohain, as in the case of looal anesthotios, and replecing the tortiary anino with primary and sooondary amines.

If the phonolio esters ahow modicinal value, an unlimltod number of osters oan bo prepared by coupling of othor modioinalig eotive group to gentiolo aold.

4100, the number 2 hydroxyl position of gentialo acid chould be attaoked by other prooedurea to attompt aubstitution in this position of gontialo aold.

The andjeos and toxiolty of tho agnthosize osters of gentisio aold aro lietod in Table XX. Tablo XXI includos the phrelogl, properties, tho sab1lity atudios, and the ooloration toat with forrio oblorido for the eatera. 
TAB LE

ANALYSLS OF SY:

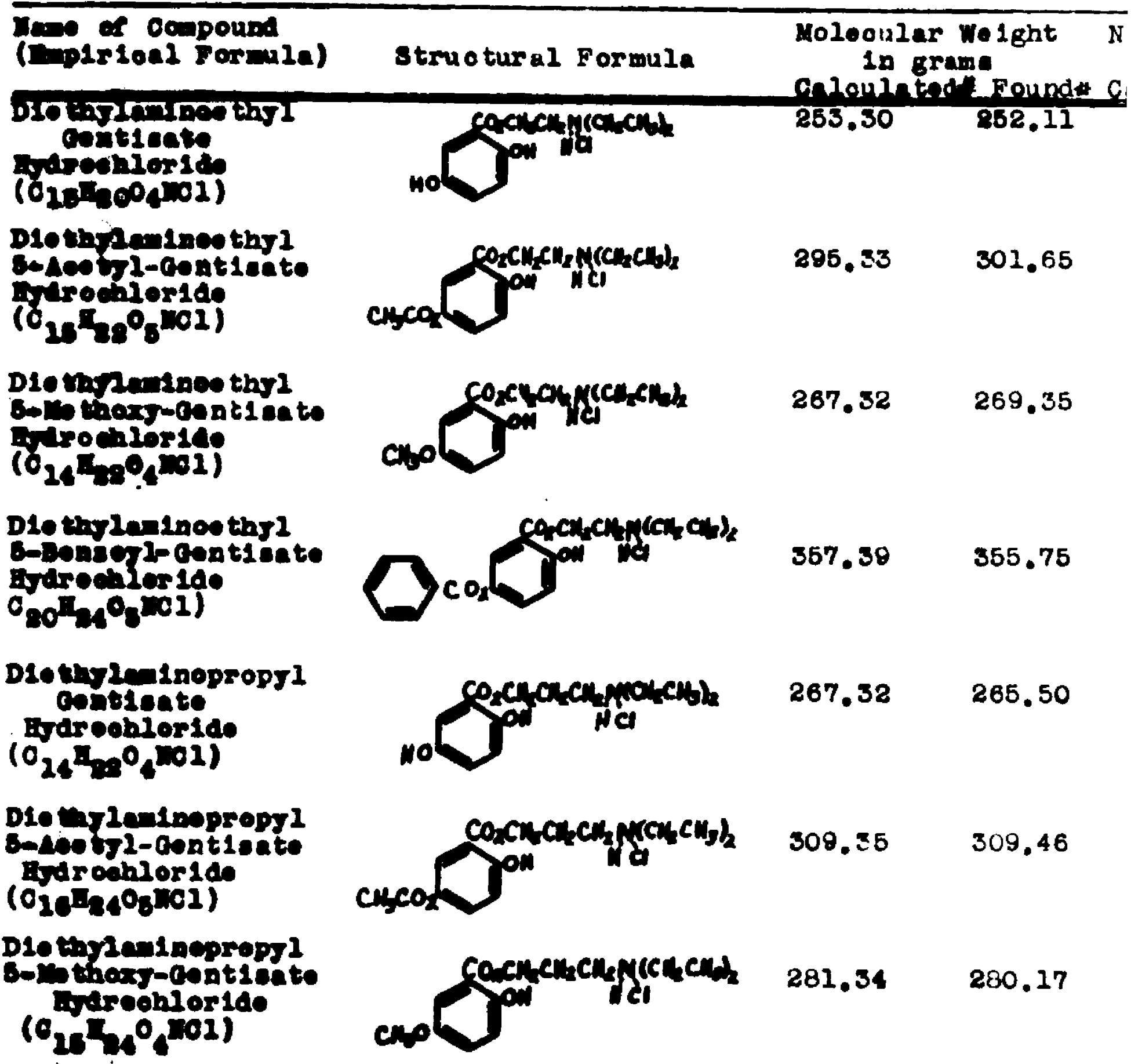


TABT: 20

LS CP SYMTHESIZ COMPOUDD

\section{1ght Hitrogen Content Chlorine content Carbon \& Hydrogen in por oont in por oont \\ Bourde oninintad Pour \\ Content in per oent \\ crioulinted Found}

32.11

4.24

4.88

12.58

12.61

$-\infty-m$.

$---\infty$

C, 54.41

$\mathrm{H}, 6.68 \mathrm{H}, 6.78$

39.36

4.61

4.70

11.68

11.62

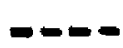

$-\infty-$

32.2

$.5 .76 \quad 3.66$

$3.42 \quad 9.00$

8.94

C. 60.85

$C, 60.40$

If, 6.14

$\mathrm{H}, \quad 6.41$

$.6 .50 \quad 4.61$

4.65

11.68

11.80

C, 65.35

$\mathrm{H}, \quad 7.30$

C, 55.45

$\mathrm{H}, \quad 7.42$

$9.46 \quad 4.05$

6.0410 .25

10.34

$-\infty-$

44.5

$0.27 \quad 4.41$

4.35

11.16

11.27

$-\infty-\infty$

22.1

$\mathrm{w}_{50}$ mg./4g. 51.2

51.5

41.7

58.5

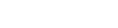


D10thylanlnopropyl 5-Bensoyl-0ont1sate HJdroohlor 1do $\left(\mathrm{C}_{82} \mathrm{R}_{28} \mathrm{O}_{\mathrm{B}} \mathrm{OI}\right)$
6- Phonylaoetjlo Gont 1010 1010 $\left(\mathrm{C}_{18} \mathrm{H}_{12}{ }^{05}\right)$

5-Paran1 trobenzojloent1010 101d $\left(\mathrm{C}_{14} \mathrm{H}_{9} \mathrm{O}_{7} \mathrm{~N}\right)$

b-Anisjl-oent1=10 $\Delta$ old

$\left(\mathrm{C}_{15^{\mathrm{B}}}{ }_{12} \mathrm{O}_{6}\right)$

6-10etyloalloglGont1 lo $101 \mathrm{~d}$ $\left(\mathrm{C}_{16} \mathrm{H}_{12} \mathrm{O}_{\eta}\right)$

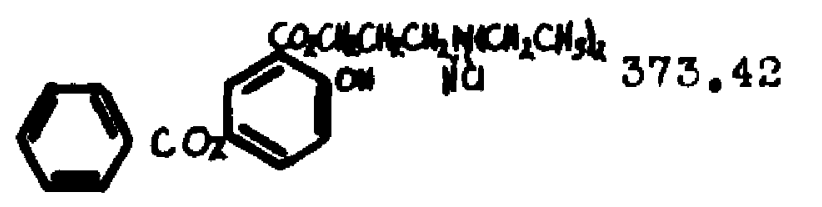

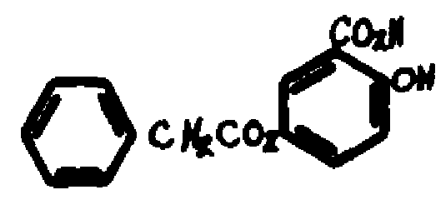

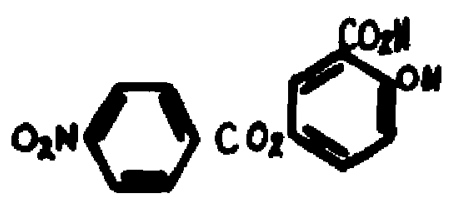

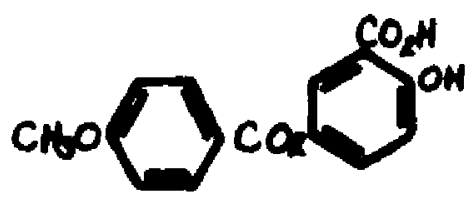<smiles>O=C1OC(=O)C2C3CCC(CC3)C1C2C(=O)O</smiles>

272.25

273.38

303.20

288.25

316.26

235.22

290.50

390.29

388.37

5, si suocinyl-

Digentigig cold (C18B120

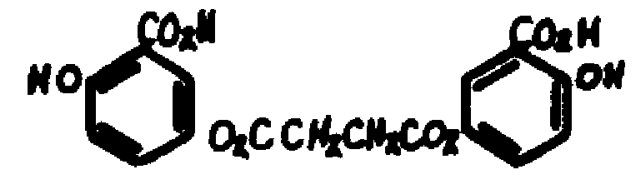

Oentia10 1010 ( $\left.\mathrm{C}_{7} \mathrm{H}_{6} \mathrm{O}\right)$

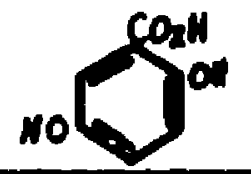

Arerago or tro values

Moloouler weight caloulated for Freo umino. 
TABLE $X X\left(\operatorname{colN}^{\prime} D\right)$

\begin{tabular}{|c|c|c|c|c|c|c|c|}
\hline 3.34 & 3.43 & 3.60 & 8.69 & 8.62 & --- & $\cdots$ & 30.3 \\
\hline 3.38 & --- & $-\infty$ & -- & $-\cdots$ & $\begin{array}{lr}\mathrm{C}, & 66.17 \\
\mathrm{H}, & 4.44\end{array}$ & $\begin{array}{rr}\text { C, } & 66.21 \\
\text { II, } & 4.51\end{array}$ & 201.3 \\
\hline 1.19 & $\cdots$ & $m$ & $-\cdots$ & -- & $\begin{array}{l}\text { C, } \\
55.46 \\
\mathrm{H}, \quad 2.99\end{array}$ & $\begin{array}{rr}\text { C, } & 55.43 \\
\text { h, } & 8.87\end{array}$ & 82.5 \\
\hline 3.50 & $\infty$ & $-\infty$ & $-\infty$ & -- & $\begin{array}{r}\text { C, } \quad 62.50 \\
\mathrm{H}, \quad 4.18\end{array}$ & $\begin{array}{r}\mathrm{C}, \quad 62.43 \\
\mathrm{H}, \quad 4.54\end{array}$ & 45.0 \\
\hline 5.23 & $=-$ & - & $-\infty$ & $\cdots$ & $\begin{array}{lr}\mathrm{C}, & 60.76 \\
\mathrm{H}, & 3.83\end{array}$ & $\begin{array}{l}\mathrm{C}, \quad 61.634 \\
\mathrm{H}, \quad 3.384\end{array}$ & 32.4 \\
\hline 8.37 & $-\infty$ & $-\infty$ & $-\infty$ & $-\infty$ & $\begin{array}{lr}\text { C, } & 55.39 \\
\text { H, } \quad 3.62\end{array}$ & $\begin{array}{rr}C, & 55.20 \\
H, & 3.82\end{array}$ & 155.0 \\
\hline - & $-\infty$ & $-\infty$ & - & $-\infty$ & $-\infty-\infty$ & $-\infty-\infty$ & 374.0 \\
\hline
\end{tabular}


TABIE XXI

Propertios of Synthesized Compounds Solub1lity

\begin{tabular}{|c|c|c|c|c|c|c|c|}
\hline $\begin{array}{l}\text { Neme of } \\
\text { Coupound }\end{array}$ & & $\begin{array}{l}\text { Morosoop } 10 \\
\text { Appenrance }\end{array}$ & Water & $\begin{array}{l}\text { Alco- } \\
\text { hol }\end{array}$ & Ethor & $\begin{array}{l}\text { Ace- } \\
\text { tone }\end{array}$ & $\begin{array}{l}\text { Crilo- } \\
\text { rofor: }\end{array}$ \\
\hline $\begin{array}{l}\text { Hothylaminoethyl } \\
\text { Gontioate } \\
\text { Hydrochlor 1de }\end{array}$ & $152^{\circ}$ & $\begin{array}{c}\text { coloriosa } \\
\text { platea }\end{array}$ & 8 & a & 1 & 1 & 1 \\
\hline
\end{tabular}

D10thylaminoothyl 133.5- colorleso 5-Acotyl-Gont1ento $134.5^{\circ}$ Needios Hrdroohloride

s s s sl:s

Diethylaminoothyl 282.3- Colorloss 5-Mothoxy-Gent1- $183.0^{\circ}$ Neodles aeto

HJdroohlor 1 de

D1e thylamlnoe thyl B-Beneoyl-Gent1- $154^{\circ}$ cate

Hydroohlor ido

Diothylaminopropjl 171.5 Gentianto Hydrochlor 1de $172.5^{\circ}$

Colorless Platea Colorloss Neodlos

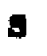

a

$910 \mathrm{~s}$ $\mathbf{3}$

Dio thylaminopropyl 1575-Acotyl-gentisate $157.5^{\circ}$ Hydroohlor 1do

D10thylaminopropyl 184.5- Colorloss 5-Ko thoxy-Qont1- $185-3^{\circ}$ Noodlos cate

Hydrochlor 1de

Colorloss Neodles

Diothlaminopropyl 5-Benzoyl-Gont1sato $142.7-$
$143.7^{\circ}$ Hrdroohlor 1do

S-Plenglaoetylcont1sio 101d

145-5- Colorloss $146.5^{\circ}$ Fibor:
5

$\mathbf{s}$

3

s

3

8

$\mathbf{B}$

1

913

8

8

$n$

1

8

8

1

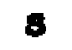

$\theta$

8

9 
TABIS XXI

of Srathesized Compounde Solub111ty

Aloo- Aoo- Chlo-

ir hol Bther tone roform

Stab111tyt

Solid Solution
Ferric

chloride

Test

- 111

92. 010

- 81.1

$\mathbf{s}$

- $81 \cdot 7$

s

- 1

1

a

-

-

a

- 1

81.8

- 1

-

๑

$+$

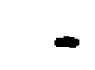

4

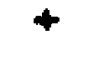

$+$

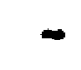

$+$

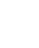

$+$

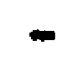

$+$

1

$-\mathbf{a}$

a

$+-b^{\prime \prime}$

$+$ 
TABLE XXI (CONT'D)

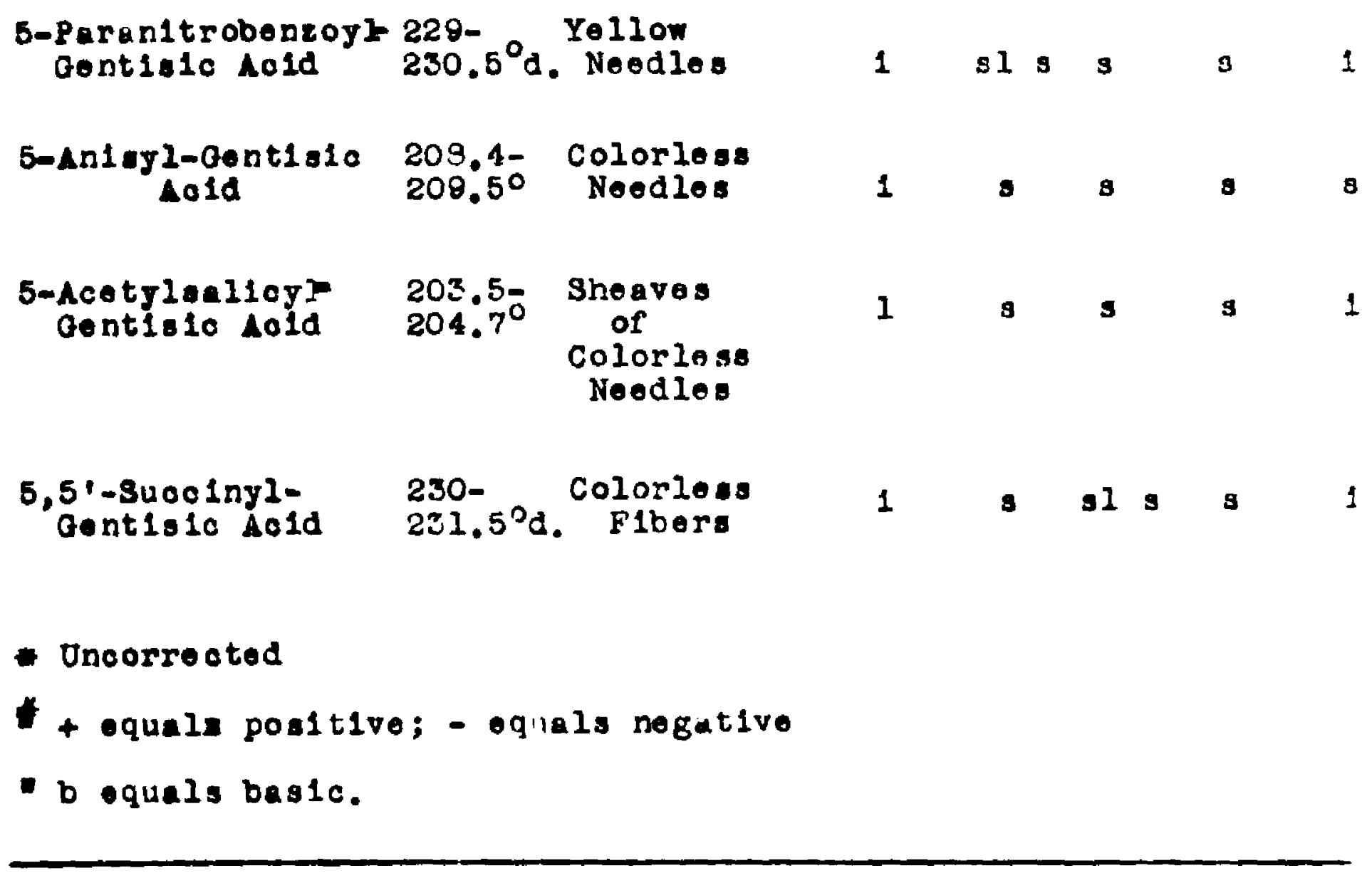


TABLE XXI (CONT'D)

101.

1

1

1 s

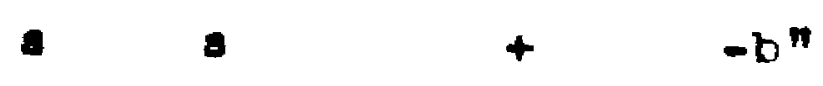

- $1+-b^{n}$

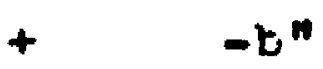

1
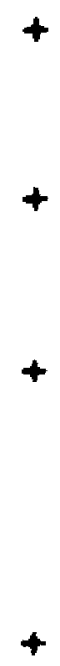

-

·

- 


\section{CONCLUSTONS}

I. Thirteon new esters of gentisic ucid wore prepared, elght of whioh are oarboxylic aold osters and five ary phonolic ectera.

A. The carboxyl10 acld ester hydrochlorides.

(1) The carboxylic acid osters were prepered in good yleld, by the interaction of the chloride of tertiary amino alcohols and gentiglo acid or substitutod gent1sic aolds.

(2) The physical properties of the compounds, 1.e. molting point, mioroscoplc appoarance and solublitty, were determinod.

(3) The carboxylic acid osters are sults, and therefore, they are readily soluble in water. However, aqueous solutions of the salts must be buffered so the colution 1s acid to Insure stab1l1 ty.

(4) qualitative and quantitative nitrogen und ohlorine content of oach oarboxyl10 aold eater salt was determined.

(5) All the oarboxyllo acid oster hydrochlorides gave a positive forric orloride tost.

(6) Diethylaminoe thyl 5-ace tyl-gentisute hydrochloride, diethylaminoethyl 5-benzoyl-gentisate hydrochloride and diethylaminopropyl gentlate hydroohloride were analyalzed for carbon and hydrogan. 
(7) A modificution of the usual procedure for determination of neutral oquivalenta of tre curboxylic acid ester hydrochloride was employed. The yrocodirc was to liberate the amine by addition of axcess standard base and thon titrate the excess base and tho anine with standard acid. B. Phonolic eaters.

(1) The number 2 hydroxyl group of gentisic acid was found to be very difficult to rauct with, if not entirely 1nert; whereas, tho number 5 hydroxyl group was very reactive.

(2) The phenol1c esters ware prepared by the interaction of the acid chloride and the various acids and the number 5 hydroxyl group of gentisic acid in alkuline media, 1.0. Schotten-Bauman reaction.

(3) The phyaical properties of the oompounds, $1 . \theta$. molting point, miorosoopio appearance and scilubility, were determined.

(4) The phonolic osters can be mado partially soluble by meking the sodium salt of the gentisin acid portion of the molecule. Although the sults may bo unstable in solution, if in tablet form, they would favor absorption of the compound.

(5) All the phenolic osters gave positive ferrjo chloride test. 
(6) 5-Paranitrobenzoyl-gentiyic acid gave a positive tost for nitrogen.

(7) Tho phonollc esters were analysized tor carbon and hydrogen.

(8) The neutral oquivalents of the phenolis esters woro deternined in the usual manner.

(9) The average equivalent of 5-acetylanlicylgent1810 acld was found to be $30 \mathrm{~g}$. too low. Therefore, doubt exista as to whether this is the correct formula of the compound.

II. The infrared apetra of the now esters of eantisic acid were analysized to prove the struoture of the conpounds. A. The carboxylic acid ester hydrochloridos.

(1) Diethylaminoethyl gentisate hydrochloride, d1othylaminoothyl 5-methoxy-gentlsate hydrochloride and tho d1ethylaminopropyl oounter-parts show orily one oarbongl function in the spootra. This indicuted osterifioation through tho oarboxylic acid of gantisic so1d.

(2) D10 thylaminoe thyl 5-acetyl-gentiate hydroohloride, diethylaminoo thyl-5-bengoyl-gontisute hydroohlorido and the diethylaminopropyl oounter-parta show two oerbonyl funotions in their spectra. This indicutes oaterifioetion through the oarboxylic aold and the number 5 hydroxyl of gent1s10 ao1d. 
B. The phenolic esters.

(I) All flve phenolic estars show two carbonyl functions in their spectra. This indicateg that the oarboxylic acid of gentisic acid is freo and that tino point of osterifioation is at the numbar 5 hydroxyl group of gentisic acid.

(2) The spectrum of 5-acetysalicyl-gentisic acid shows only ono carbonyl functiun. Therefore, doutt exists as to whether the proposed formula is the true neture of the compound.

II. The $L_{50}$ of each new oster of jentisic acid was detormined by intravenous infection of the compounds inlo white m100.

A. The carboxyllc acli ester hydrochlorides.

(1) The most toxic of the carboxylic acid ester hydrochlorides is $58.5 \mathrm{mg} . / \mathrm{Kg}$. on mice whereas the loast tox 1c is $22.1 \mathrm{mg} . / \mathrm{Kg}$.

(2) D1ethylaminoethyl 5-methoxy-gent1sate hydroohloride is the most toxic compound of the diethylaminoethanol esters and diethylaminopropyl 5-methoxygentisate hydroahloride is the most toxic compound of the diethylaminopropyl osters. The latter is the most toxio compound of all the carboxylio acld ester hydroohlorides.

D10thylaminoethyl 5-acetyl-gentisate hydrochlorlde 1. the loast toxic oompound of the diethylaminoetigl 
asters and diothylaminopropyl kiatisate nydrochiorido 1s the loast toxio oonpound of the diathylaminopropyl osters. The lattrir is the least toxic c mpotind of trie carboxylic acld ester hydrochlorides.

5-aoetyl, 5-methoxy and 5-benzoyl gentialc acid esters of diethylaminopropunoi hydroohloride are mors toxio compounds than the diethylaminoethanol derivaties of the sume acid. B. The phenol1c esters.

(1) The phenolic asters minimum and maximum toxicity varles from $201.3 \mathrm{mg} . / \mathrm{Kg}$. to $32.4 \mathrm{mg} . / \mathrm{Kg}$, respectively on $\mathbf{m} 1 \mathrm{ce}$.

5-phenylacetyl-gentisic audd is the loust toxio phenolic ester and 5-acetylasalicyl-gentisic acid is the most toxic.

Substitution on the benzene ring of the phenolic osters seems to groatly incriase the toxicity of this Group of compounds. 


\section{BIBIIOGRAPHY}

(1) Burger, A., Modiolnal Chomistry, Volume I, Intersolonoo Publishers, Inc.. Now York, 1951, p. 129.

(2) Rovenet1ne, E. A., Ann. N. Y. Aoad. So1., s1 145 $(1048)$.

(3) Suder, C. M., Modicinal Chowletry, Volumo I, John Wlioy \& Sons, Ino., Now Iork, 1951, pp. 183, 297.

(4) Merok Index, 6 th Ed., Morok \& Co., Inc., Now Jorsey, 1952, $p .80$.

(5) Camelin, A., Aocojor, P., Pellorat, J., Lafuna, J., and Colrault, R., Soc. Mod. Hop. Par1s. 826, (1949).

(6) Moyer, K., and Ragen, C., Scionoo, 108, 281 (1948).

(7) Guerre, F., Solonoe, 103, 686 (1946).

(8) Guerra, F., J. Pharmaool, and Exptl. Therap., 87,193 (2046).

(9) Heyer, K., and Palmer, J., Am. J. Opthalmology, 19, $859(1936)$.

(10) Durkn-Regnale, F., Baot. Rev., 6, 197 (1942).

(11) Moclean, D., J. Path, Baot., 53, 256 (1941).

(12) Kondall, F. E., Holdolborger, M., and Dawson, M. H., J. Biol. Chem., 118, 61 (1937).

(13) Crowloy, N., J. Path. Bact., 56, 27 (1944).

(14) Dorfman, A., Kolmors, E. J. and ott, M. L., Proc. Soc. Bxpti. Blol. and Mod., 64, 357 (1947).

(15) P1ke, R. M., Sc1ence, 105, 391 (1947).

(16) Noyor, K., Phys101. Rov., 27. 337 (1947).

(17) Swyor, O. I. M., Bloohom. J., 4F, 32 (1948).

(18) Mejer, K., and kagen, C., Fod. Proo., 7, 173 (1948).

(19) Mod. Koman's J.. 57, 9 (1950).

(20) Roseman, S., and Dorfman, A., J. B101. Chem., 192, $105(1951)$. 
(21) Lowonthal, J. und Gagnoil, J., Sc1ence, 105, 618 (1947).

(22) Roseman, S, Poarson, F., and Dorfman, A., Fed. Proc., B. $245(1849)$

(23) Iowenthal, J., and aegnon, J., Cen. J. Kesegrch, 26E, $800(1948)$.

(24) Caleanlok, B. and Beutner, R., Proo, Soc. Bxptl. B10l. and Mod.. 72, 629 (1349).

(26) Lon1r, J. B., Lombard1, A. A., and Svigals, C. S., Buil. N. Y. Mod, Coll.. 13, 91 (1950).

(26) Lanoet, 860, 773 (1951).

(27) Thib́bet, L., Simon, $\dot{B}$, Iaroret, J., and Bertholay, ,., Compt. Rónd.. 232, í12 (195i).

(28) Sohnoffer, I. F., Rashkoff, I, A., and Miglbow, R, S., Ciroulation, 2, 265 (1950).

(29) Lanoet, 257, 473 (1949).

(30) Orj, H., Bruxelles-mbd., 29, 1401 (1949).

(31) Minerva Mod., 41,450 (1950).

(32) Batterman, B. C., Krylo, L. S., and Dann, S., Fod. Proo. 10, 278 (1951).

(33) Caprett $1, Q_{.,}$and Arduini, U., olor. Cl1r. Med., 31, $677(1950)$.

(34) Ilkhetsohaff, A., Z. Phys10I. Chom., 21, 422 (1895).

(36) Staub, H. and Hoben, J., Fortaohritte der He1letof $\{$ chomie, 2 Abt.. Bd. II, J. Springer Berlin-Ie1pzig, $1932,3.594$.

(36) Ginoulhiao, B., Somenza, F, and Ha1nard1, L., Boll. Soo. Ital. B101 Sper., 26, 241 (1950).

(37) Bo1lsto in Handbuch Dor Organishon Chomie, Vislume 10, J. Springer Borlin-Gbttingen-Heldelborg, $1919-1940$.

(38) Horfor, M., U. S. Patent 2,541,651, Fob. 13, 1951.

(39) Hoffor, "., Gorman Fatent 804,211, Apr11 16, 1951.

(40) Lautor, W. M. and Bruoar, M. D., U. S. Patent 2,543,976, Mar. 6. 1951. 
(41) Suder, C. M., Modicinal Chomistry, Volume I, John Wilog \& Sons, Now York, 1951, P. 153.

(42) Horenote1n, H, and Pahliche, M., Ber. 71, 1644 (1938).

(43) Suder, C. M., Mediolnal Chemlstry, Volume $I$, Jonn Hiloy Sons, Now York, 1851, p. 155.

(44) Von Braun, J., Brlundsorf, 0 . and $R I$ th, K., Ber. 55, 1666 (1922).

(4B) Fieser, L. F., Experiments in Organle Chemlatry, 2nd Bd. D. C. Hoath \& CO., Now York, 1951, P. 62.

(46) Cope, A, C. and Hancook, B. M., J. Am. Chem. Soc. 66, i448 (1944).

(47) Kopotoohn1, B. and Ladislaus, K., Bor. 47, 235 (1914).

(48) merensto in, R., Friedleanders Fortsohr. Toorfurhon-fabr., 12, $667(1914-16)$.

(49) I1nhorn, A, and Von Bagh, A., Ber. 43, 328 (1910).

(30) Mosivaln, 3. M., The charaoterization of Organic Compound, Tho Meoklilan Company, Now York, 1947, p. 193.

(51) Hiokenbottom, W. J., Reaotions or Organic Compounds, and Bd., Iongmans, Greon \& Co., Now York, 1948, p.98.

(52) Shriner, R. L, and Fuson, K. C., The Systomatic Idontifloation of Organio Compounds, 3rd Ed., John Wiley sone, Inc., Now York, 1940, p. 54.

(53) Hloderl, J. B. and Nlodorl, V., Mloro Mo thods of Quant1tat1re Organ10 Analyais, and Bd., John $1110 \mathrm{~g}$ \& Sona, Ino., Naw York, 1948, P. 69.

(54) W1llard, H. H, and Furman, N. H., blomentary quant1tat1vo Anaiga1s, 3rd $\mathrm{Ed}$, , $\mathrm{D}$. Van Nostrand Co., Inc. New York, 1940, p. 178.

(55) MaBay, A. J., Jenkena, G, L. and Data, J, B., J. Am. Pharm. Assoo. 39, 138 (1950).

(56) Sohreiber, R. S., Organ 10 Syntheses, John W1 log \& Sona, Ino., Now York, 31, 1951, p. 37.

(57) Shirloy, D. A., Preparation of Organio Intermodiatos, John wiley \& Bons, Ino., Now York, 1951, p. 126. 
(41) Suder, C. M.. Modicinal Chomistry, Volume I, John Wlíy \& Sóns, Now York, 1951, P. 153.

(42) Horenstoin, H, and Pâhlicho, M., Bor. 71, $1644(1338)$.

(43) Suder, C. M., Modlo1nel Chemlstry, Volume I, Jonn Wlioy Sóns, Now York, 1951, P. 155.

(44) Von Braun, J., Brtundsorf, 0 , and $R t_{\text {th }}, K$, , Her. 55 . 1666 (1922).

(45) Fioger, L. F., Experiments in Organic Chemistry, and Bd. D. C. Hoath \& Co.. Now York, 1951, p. 62.

(46) Cope, A, C, and Hancook, E. M., J. Am. Chem, Soc. 66, 1448 (1944).

(47) Kopstoohn1, B. and Ladislaus, K., Bor, 47, 235 (2914).

(48) merenetoin, R., Friedleanders Fortschr. Teerfarhen-. fabr.. 12, $667(1914-16)$.

(49) Elnhorn, A. and Von Bagh, A., Ber. 43, 328 (1910).

(Bo) Mosivain, 3. M., The Charaoterization of Organio Ocmpounda, Tho Maokllian Company, Now York, 1947, p. 193.

(b2) Hiokenbottom, W. J., Reaotions of Organic Compounds, Ind Ed., Longmans, Groen \& Co.. Now York, 2948, p.98.

(68) shriner, R. I. and Fueon, R. C.. The Syatemetic Identifioation of Organio Compounda, 3rd Ed., John W11ey sons, Ino., Now York, 1840, p. 54.

(B3) Miederl, J. B. and Niedorl, V., Mloro Mo thods of Guant1tat1re Organio Analysio, and Ed.. John Wiley \& Sone, Ino., Now York, 1948, P. 69.

(B4) W1llard, H. H, and Furman, N. H., blomontary quant1tet1ro Anaige1\%, 3rd Ed., D, Van Nostrand Co.. Inc. New York, 1840, p. 178.

(55) MaBay, A. J., Jonkens, G. L. and Data, J. B., J.Am. Pharm. Assoo, 39, 138 (1950).

(56) Sohreiber, R. S., Organ10 Syntheses, John wileg ic Sons, Ino., Now York, 31 , 1951, p. 37 .

(57) Shirlej, D. A., Preparation of Organio Intermodiatos, John wiley \& Sons, Ino., Now York, 1951, p. 116. 
(58) Buohner, R. R., J. Am, Chem. So0., 71, 2578 (1949).

(50) Ioscer, R, and Gad, O., Bor. 59, 23: (1926).

(60) Peiser, I. F., Exporimonts in Organic Chemintry, and Bd.: D. C. Heath \& Co., Now York, 1941, p. 76.

(61) araobe, C, and Marte, B., Ann, 340, 213 (1905).

(68) Bergonan, $M$, and Dangeohet, P., Ber, 52, 387 (1919).

(63) Sh1rley, D. A., Preparation of Organio Intermediates, John Wiley d Sons, Ine.. Now York, 1951, P. 119.

(64) Molacter, $I_{0}$ and Amann, F.F., J. Am. Chem. Soo. 50, 246 (1988).

(65) Masivain, S. M. The Chareoterisation of Organio Compound:, Tho Heoklilan Company, Now York, 1947, P. 141.

(68) Voltindor, D., Ann, 280, 177 (1894).

(e7) G1bb, T. R. P. Jr., Opt1oal lo thodg of Chemloal Analy10, Ist Ra., Mograw-H111 Book Company, Ino, Now Torie, 1048, p. 119.

(0B) W121ard H. H., Merritt, I. I, Jr., and Dean, I. A., Inotrumental Mo thoda of Analjeis, and Ed.. D. VanHootrand Ccompany, Ino., Xow York, 2951, P. 51.

(60) Randal1, H, H., Fowler, R, D, Fueon,, and Dangl, J. R.. Infrared Determination of orgunio Molooules, D. Vanliostrand Compary, Ino.. Now York, 1948, P. 1 .

(70) Bohrog, B., Axoh. Bxptl. Path. Pharmakol., 240, 237 $(2020)$. 
A1. UISOMRAPHY

I, J. Frank Nagh, was born in East Canton, Ohio, "uy 19, 1924. I roolved mJ secondary school edaciation in the public schoole of the city of liat canton, Ohlo arid osnaburg Township. My uniargraduate trainind was obtulned at Onio State University, from which I recelved the degree of Bachelor of Science in 1948. In 1949 I was gppointed Upjohn fillow in Pharmaceutioal Chemistry, collefs of Pharmacy, Ohio state University. I hold this followship for a period of three years while completing the requirements for the dogree Doctor of Hhllosophy. 